\author{
UNIVERSIDADE DE SÃO PAULO \\ ESCOLA DE EDUCAÇÃO FÍSICA E ESPORTE \\ DEPARTAMENTO DE BIODINÂMICA DO MOVIMENTO DO CORPO \\ HUMANO
}

JOÃO LUCAS PENTEADO GOMES

Efeito do treinamento físico aeróbico sobre a expressão de myomiRs circulante e muscular em modelos experimentais de câncer 
JOÃO LUCAS PENTEADO GOMES

\section{EFEITO DO TREINAMENTO FÍSICO AERÓBICO SOBRE A EXPRESSÃO DE myomiRs CIRCULANTE E MUSCULAR EM MODELOS EXPERIMENTAIS DE CÂNCER}

Dissertação apresentada à Escola de Educação Física e Esporte da Universidade de São Paulo, como requisito parcial para a obtenção do título de Mestre em Ciências

Área de Concentração: Biodinâmica do Movimento do Corpo Humano

Orientadora: $\operatorname{Prof}^{\mathrm{a}} \operatorname{Dr}^{\mathrm{a}}$ Edilamar Menezes de Oliveira

Laboratório de Bioquímica e Biologia Molecular do Exercício 


\section{Ficha Catalográfica}

Autorizo a reprodução e divulgação total ou parcial deste trabalho, por qualquer meio convencional ou eletrônico, para fins de estudo e pesquisa, desde que citada a fonte.

Catalogação da Publicação

Serviço de Biblioteca

Escola de Educação Física e Esporte da Universidade de São Paulo

Gomes, João Lucas Penteado

Efeito do treinamento físico aeróbico sobre a expressão de myomiRs circulante e muscular em modelos experimentais de câncer / João Lucas Penteado Gomes. - São Paulo : [s.n.], 2017. $84 \mathrm{p}$.

Dissertação (Mestrado) -- Escola de Educação Física e Esporte da Universidade de São Paulo.

Orientadora: Profa. Dra. Edilamar Menezes de Oliveira

1. Treinamento físico 2. Treinamento aeróbico 3. Câncer 4. Músculo esquelético I. Título. 


\section{Folha de avaliação}

GOMES, João Lucas Penteado

EFEITO DO TREINAMENTO FÍSICO AERÓBICO SOBRE A EXPRESSÃO DE myomiRs CIRCULANTE E MUSCULAR EM MODELOS EXPERIMENTAIS DE CÂNCER

Dissertação apresentada à Escola de Educação Física e Esporte da Universidade de São Paulo, como requisito parcial para a obtenção do título de Mestre em Ciências

Área de Concentração: Biodinâmica do Movimento do Corpo Humano

Orientadora: Prof ${ }^{a}$ Dr ${ }^{a}$ Edilamar Menezes de Oliveira

Laboratório de Bioquímica e Biologia Molecular do Exercício

Aprovado em:

Banca examinadora

Prof.(a) $\operatorname{Dr}(a)$ Instituição

Julgamento Assinatura

Prof.(a) $\operatorname{Dr}(a)$ Instituição

Julgamento Assinatura

Prof.(a) $\operatorname{Dr}(\mathrm{a})$ Instituição Julgamento Assinatura

Prof.(a) $\operatorname{Dr}(\mathrm{a})$ Instituição

Julgamento Assinatura 


\section{Agradecimentos}

Meu primeiro agradecimento, como deveria ser, é a minha doce Mãe (Dona Neusa); toda dedicação e doação e até mesmo sacrifícios dessa mulher me possibilitaram uma boa educação e principalmente permitiu que eu pudesse estar em lugares onde poucos daqueles da onde eu vim acessaram. Todas as conquistas da minha vida têm ela como fomentadora, maior conselheira e apoiadora.

Agradeço também a toda a minha família pelo carinho prestado e o incentivo dado para que eu nunca desistir. Mas em especial meu Pai pelo apoio e carinho, e aos meus avós, Dona Maria e Seu Ju, que tanto auxiliaram meus pais na minha criação. Em destaque agradeço ao meu irmão André que todo dia me mostra que existe uma geração que vem depois de mim e que eu tenho por obrigação entregar meu melhor todos os dias.

A minha esposa Carol por ser minha grande companheira e melhor amiga durantes todos esses anos; também por estarmos juntos construindo um lindo futuro e por partilharmos nossas conquistas.

Aos meus amigos que caminham ao meu lado em todas as horas pelos momentos divertidos, pelos conselhos dados, pela conversa "jogada fora". Mas em especial os padrinhos de casamento, casa e Lu, que já são parte da minha família.

Ao pessoal do Laboratório de Bioquímica e também o de Fisiologia. Ao Gabriel por tanto ter me ajudado com ideias e ajudando muito no desenvolvimento do meu trabalho, sem ele esse trabalho não teria sido feito. E também ao Tiago por ter me ajudado tanto na realização desse trabalho. A Camila, Noemy e Clara pelos momentos divertidos no laboratório e por toda ajuda que me deram. A Fernanda, Aline, Telminha, Glorinha, Paulinho, Vanessa, Ney, Stephano e todos os que de alguma maneira me auxiliaram nas rotinas do laboratório e pelo convívio agradável. E a professora Edilamar por ser um exemplo de trabalho e dedicação e por tanto ter me ajudado no meu crescimento acadêmico.

Agradecemos ao apoio financeiro da Fundação de Amparo à Pesquisa do Estado de São Paulo (FAPESP), o trabalho está vinculado aos seguintes processos: bolsa de mestrado ํㅡㄹ 2015/04788-7 e temático ํㅡ 2015/22814-5. 
O que importa na vida não é o simples fato de ter vivido. A diferença que fazemos na vida dos outros que vai determinar a importância da vida que conduzimos.

Nelson Mandela 


\section{Resumo}

Gomes, JLP. Efeito do treinamento físico aeróbico sobre a expressão de myomiRs circulante e muscular em modelos experimentais de câncer. 2017, dissertação de mestrado - Escola de Educação Física e Esporte da Universidade de São Paulo.

Câncer é o nome que se designa para um conjunto de mais de 100 doenças. As células cancerosas acumulam mutações e apresentam uma alta velocidade de divisão celular, dessa forma, o câncer tem um caráter progressivo e degenerativo; sendo um problema de saúde pública mundial (INCA, 2017). Existem diversas comorbidades associadas ao câncer que levam a maior índice de mortalidade e ao agravamento da doença, uma destas é a caquexia. Os microRNAs são uma classe de moléculas que tem sido altamente investigada por estar relacionada com diversos fatores fisiológicos e também patológicos (AMBROS, 2001).

Sabe-se que diversos microRNAs tem expressão alterada em indivíduos com câncer. Essas alterações na expressão dos microRNAs são encontradas na circulação sanguínea, no tumor e em alguns tecidos, como o muscular esquelético e cardíaco (CHEN et al., 2014). Por outro lado, o exercício físico aeróbico provoca profundas adaptações músculo esquelético, inclusive em condições patológicas. Uma das mais marcantes é a normalização do equilíbrio entre a síntese e a degradação de proteínas no miócito esquelético (CUNHA et al, 2012). O exercício físico aeróbico tem um papel importante na regulação da expressão de diversos microRNAs. Ainda, apresenta potencial terapêutico para restaurar a expressão de diversos microRNAs alterados presentes em diferentes doenças (FERNANDES et al., 2011).

Neste trabalho analisamos a expressão de microRNAs enriquecidos no músculo esquelético (myomiRs) utilizando dois modelos MMTV-PyMT (câncer de mama, não caquético) e CT26 (câncer de cólon, caquético). Esses animais foram divididos em grupos sedentários e treinados e os controles eram animais saudáveis também divididos em sedentários e treinados.

Observamos que os animais do modelo MMTV não apresentaram perda da função e massa muscular, entretanto dois myomiRs, miR-206 e 486, tem a expressão alterada no músculo esquelético e na circulação em função do câncer e o exercício físico não influencia na expressão dos mesmos. Ainda avaliamos os mesmos parâmetros no modelo CT26; A expressão dos myomiRs-206 e 486 também está alterada na circulação e no musculo esquelético e o exercício físico não influencia a expressão destes microRNAs. Nesse modelo a expressão da proteína PI3K está diminuída e de PTEN está aumentada em função do câncer.

Nossos resultados indicam que os microRNAs 206 e 486 tem a expressão alterada no tecido muscular e na circulação em decorrência do câncer, independente da caquexia, e, podem ser marcadores de prejuízos nas vias de síntese proteica no tecido muscular.

Palavras chaves: myomiRs; Câncer, Treinamento ísico aeróbico, Músculo esquelético, Caquexia. 


\begin{abstract}
Gomes, JLP. Effect of aerobic physical training on the expression of circulating and muscular myomiRs in experimental models of cancer. 2017. Dissertation (Master). - Escola de Educação Física e Esporte, Universidade de São Paulo, São Paulo. 2017.

Cancer is the name designated for a set of more than 100 diseases. Cancer cells can be very aggressive, uncontrollable and with a high rate of cell division, so cancer has a progressive and degenerative nature and is a problem of global public health (INCA, 2017). There are several comorbidities associated with cancer that lead to higher mortality and worsening of the disease, one of which is cachexia. MicroRNAs are a class of molecules that has been highly investigated for being related to several physiological and also pathological factors (AMBROS, 2001).

It is known that several microRNAs have altered expression in individuals with cancer. These changes in the expression of microRNAs are found in the bloodstream, tumor and in some tissues, such as skeletal and cardiac muscle. (CHEN et al., 2014). On the other hand, aerobic physical exercise causes profound skeletal adaptations, including in pathological conditions. One of the most striking is the normalization of the balance between synthesis and protein degradation in the skeletal myocyte (CUNHA et al, 2012). Aerobic physical exercise plays an important role in the regulation of the expression of several microRNAs. It has therapeutic potential to restore the expression of several altered microRNAs present in different diseases (FERNANDES et al., 2011).
\end{abstract}

In our study we analyzed the expression of microRNAs enriched in skeletal muscle (myomiRs) using two models MMTV-PyMT (breast cancer, noncachectic) and CT26 (colon cancer, cachectic). These animals were divided into sedentary and trained groups and controls were healthy animals also divided into sedentary and trained.

We observed that MMTV animals showed no loss of function and muscle mass, however, two myomiRs, miR-206 and 486, have altered expression in skeletal muscle and circulation as a function of cancer, and physical exercise does not influence their expression. We also evaluated the same parameters in the CT26 model; The expression of myomiRs-206 and 486 is also altered in the circulation and skeletal muscle, and physical exercise does not influence the expression of these microRNAs. In this model the expression of PI3K protein is decreased and PTEN is increased as a function of cancer.

Our results indicate that microRNAs 206 and 486 have altered expression in muscle tissue and circulation due to cancer, independent of cachexia, and may be markers of damage in the pathways of protein synthesis in muscle tissue.

Keywords: MyomiRs; Cancer, Aerobic physical training, Skeletal muscle, Cachexia. 


\section{Lista de figuras}

Figura 1: Biogênese dos microRNAs (Winter, Jung, Keller, Gregory, \& Diederichs, 2009)

Figura 2: Desenho experimental do estudo 1; modelo MMTV-PyMT

Figura 3: Desenho experimental do estudo 2; Modelo CT26

Figura 4: A) Frequência cardíaca de repouso; B) Distância máxima percorrida no teste de esforço máximo. Batimento por minuto (BPM); C) atividade da enzima citrato sintase.

Figura 5: A) Evolução da massa corporal ao longo do tempo; B) Volume tumoral ao longo do tempo; C) Peso da gordura perigonadal corrigido pelo comprimento da tíbia.

Figura 6: A) Peso dos músculos corrigido pelo comprimento da tíbia B) Área de secção transversa do músculo sóleo e tibial anterior C) Comprimento da passada obtido no teste de deambulação

Figura 7: A) Expressão do microRNA-133a no músculo tibial anterior B) Expressão do microRNA-133b no músculo tibial anterior C) Expressão do microRNA-1 no músculo tibial anterior.

Figura 8: A) Expressão do microRNA-206 no músculo tibial anterior B) Expressão do microRNA-486 no músculo tibial anterior. Controle Saudável Sedentário (SS), Saudável Treinado (STR); Câncer Sedentário (CS); Câncer Treinado (CTR). * $p<0,05$.

Figura 9: A) Expressão do microRNAs 133a no soro B) Expressão do microRNAs 206 no soro C) Expressão do microRNAs 486 no soro.

Figura 10: A) Expressão dos microRNAs-133a, -133b e -206 no tumor B) Expressão dos microRNAs-133a, -133b e -206 no tumor comparado com músculo esquelético

Figura 11: A) Expressão da proteína AKT B) Expressão da proteína PI3K C) expressão da proteína mTOR D) Expressão da proteína PTEN E) imagem representativa das bandas de proteínas 
Figura 12: A) Expressão da proteína FOXO1a B) Expressão da proteína pFOXO1a C) expressão da proteína FOXO3a D) Expressão da proteína pFOXO3a E) imagem representativa das bandas de proteínas.

Figura 13: A) Expressão da proteína HDAC4 B) Expressão da proteína PAX7 C) expressão da proteína PAX3 D) imagem representativa das bandas de proteínas.

Figura 14: A) Distância máxima percorrida no teste de esforço máximo B) atividade da enzima citrato sintase

Figura 15: A) Volume tumoral ex vivo B) Massa corporal total C) massa corporal livre do tumor D) Peso da gordura perigonadal

Figura 16: A) Peso dos músculos sóleo, plantar, gastrocnêmio e tibial anterior B) Grip- força de preensão

Figura 17: A) Expressão do microRNA-206 no tibial anterior B) Expressão dos microRNA-486 no tibial anterior

Figura 18: A) Expressão dos microRNA-206 na circulação B) Expressão dos microRNA-486 na circulação.

Figura 19: A) Expressão da proteína $A K T$ B) Expressão da proteína PI3K C) Expressão da proteína mTOR D) expressão da proteína PTEN E) Expressão da proteína FOXO3a F) Expressão da proteína pFOXO3a G) imagem representativa das bandas de proteína.

Figura 20: A) Expressão da proteína HDAC4 B) Expressão da proteína PAX7 C) Expressão da proteína PAX3 D) imagem representativa das bandas de proteína. 


\section{Resumo}

\section{Abstract}

\section{Lista de figuras}

\section{Sumário}

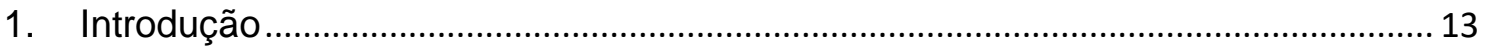

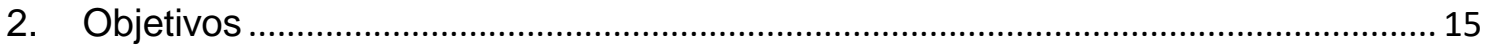

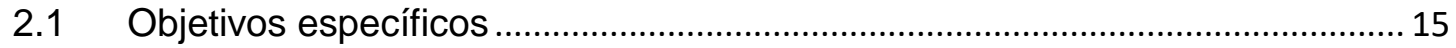

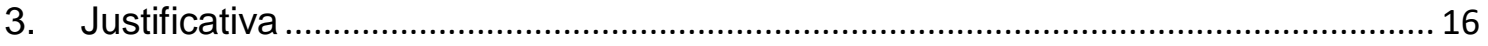

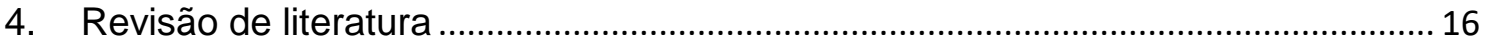

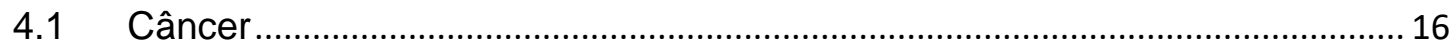

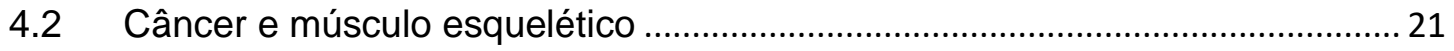

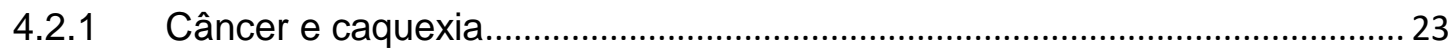

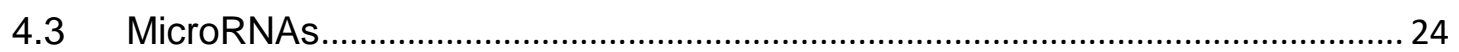

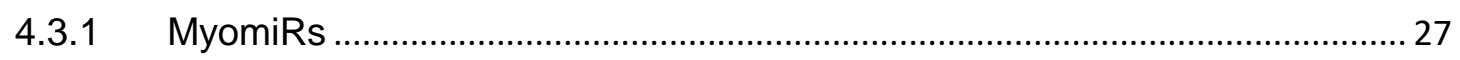

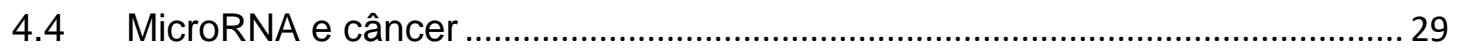

4.4.1 MicroRNA, câncer e músculo esquelético ....................................................... 31

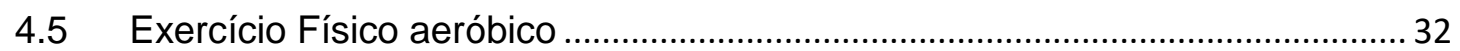

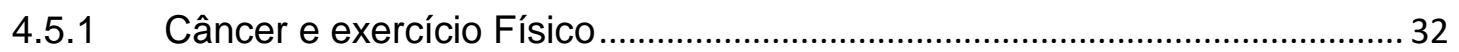

4.5.2 MicroRNA e exercício físico aeróbico ................................................................ 33

4.6 MicroRNA, câncer e exercício físico.................................................................... 34

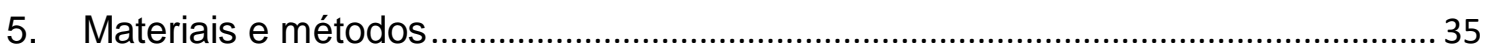

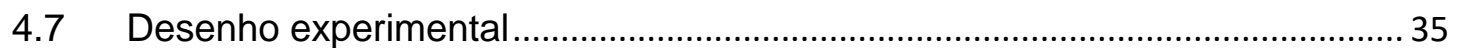

4.8 Medidas morfológicas e hemodinâmicas................................................................. 38

4.9 Testes funcionais e protocolo de treinamento ….................................................. 39

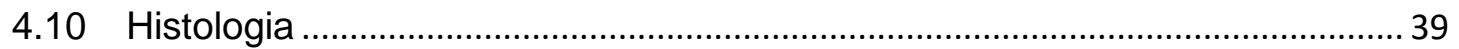

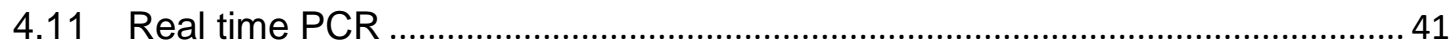

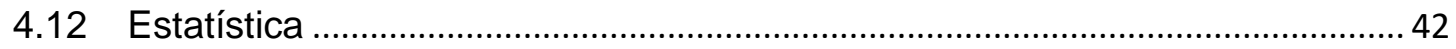

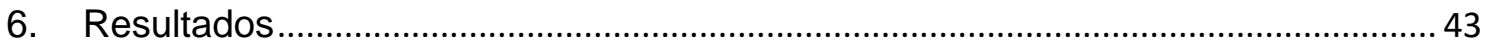

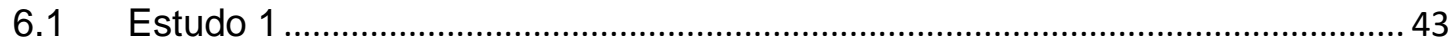

6.1.1 Marcadores de treinamento ......................................................................... 43

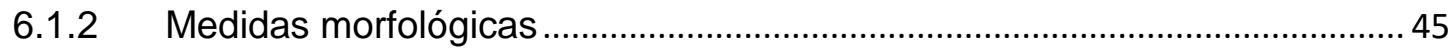

6.1.3 Caracterização do músculo esquelético ……….......................................... 47

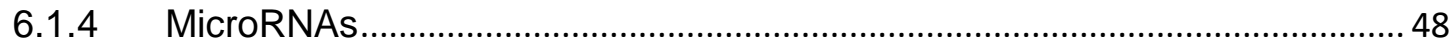




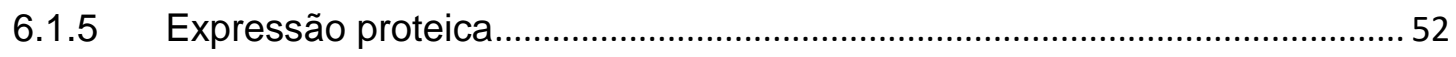

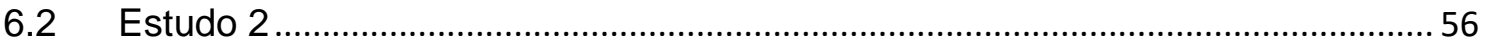

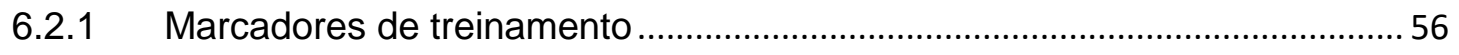

6.2.2 Medidas morfológicas e funcionais ................................................................... 57

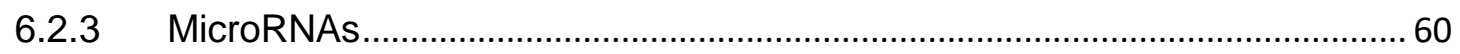

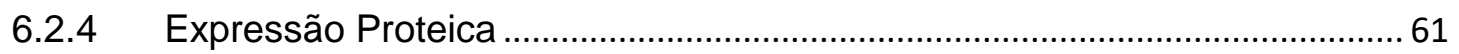

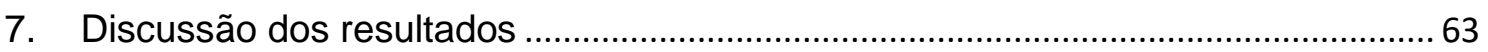

7.1 Resumo dos resultados e conclusão. ................................................................... 74

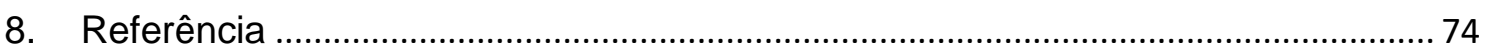




\section{Introdução}

O câncer é o nome dado a um conjunto de doenças que tem em comum um complexo processo que leva a células saudáveis a gerar uma população de clones capazes de evadir sinais de controle de proliferação, crescimento, morte celular e dessa forma impedir a homeostase celular. Essa população de células geradas difere totalmente do tecido originário, o conjunto de células cancerosas evolui de forma rápida e progressiva e sua iniciação se dá através de mutações que estão relacionadas com o aumento da expressão de genes promotores de neoplasias (oncogenes) e a diminuição de supressores neoplásicos (antioncogenes), o conjunto dessas mutações desencadeiam alterações celulares complexas que levam ao escape de sistema de controle do ciclo celular e apoptose, bem como o escape do sistema imune, aumentando a capacidade de crescimento e multiplicação dessas células. O acúmulo de mutações leva as células cancerosas a apresentarem diferentes comportamentos, os quais variam conforme o tipo de câncer e tempo da doença, dessa forma não há homogeneidade na doença, entre as células do próprio tumor, assim todo esse conjunto faz com que o tratamento da doença seja de difícil entendimento (Hanahan \& Weinberg, 2011).

Muitas evidências mostram que as células cancerosas se acumulam formando o tumor maligno no órgão de origem, entretanto o tumor torna-se capaz de comunicar com outros órgãos e tecidos causando severos prejuízos sistêmicos (Acunzo \& Croce, 2015; Kim et al., 2013; Peinado et al., 2012; R. Siegel et al., 2013; Yuan et al., 2014), o músculo esquelético é um dos tecidos que sofrem grande influência do câncer. A caquexia é uma comorbidade do câncer que afeta a musculatura esquelética gerando severo prejuízo no morfologia e na função desse tecido (Groarke, Cheng, Jones, \& Moslehi, 2013; Sandri, 2015).

Caquexia é uma síndrome comum decorrente de doenças neoplásicas avançadas, que é caraterizada pela perda progressiva da massa corporal, principalmente do músculo esquelético e tecido adiposo e gera grandes prejuízos funcionais e na qualidade de vida dos indivíduos. Assim, a caquexia leva ao agravamento da doença e estima-se que essa comorbidade é 
responsável por aproximadamente 20\% das mortes por câncer (Groarke et al., 2013).

Uma das prováveis vias de comunicação do tumor com outros tecidos sãos os microRNAs.

Esta classe de moléculas tem sido altamente investigada por estar relacionada com diversos fatores fisiológicos e também patológicos; vários estudos vêm demonstrando que os microRNAs controlam, postranscricionalmente, a expressão de diversos genes em diversos tecidos (AMBROS, 2001). No câncer essas moléculas apresentam expressão anormal e efeitos biológicos nas vias de proliferação, crescimento, angiogênese, além de estarem relacionados com a promoção de metástases (Chan, Krichevsky, \& Kosik, 2005; Müller et al., 2014; Weidong Zhou et al., 2014; Weiying Zhou et al., 2014). Os microRNAs podem ser encontrados na circulação dos indivíduos; e no caso de expressão anormal, por exemplo em decorrência de doenças como o câncer, essa moléculas circulantes podem ser biomarcadores e/ou meio de comunicação entre tecidos, tal como mencionado anteriormente (Creemers, Tijsen, \& Pinto, 2012).

A literatura aponta que indivíduos com câncer apresentam alterações na expressão de diversos microRNAs, e essas alterações na expressão dos microRNAs são encontradas na circulação sanguínea (FRÈRES et al., 2015; MÜLLER et al., 2014), no tumor (LEE et al., 2016) e em alguns tecidos como o muscular esquelético e o cardíaco gerando prejuízos no balanço de síntese proteica (CHEN et al., 2014).

O músculo esquelético e cardíaco apresenta um conjunto de microRNAs que são especificamente expressos nesses tecidos, estes são chamados de myomiRs. É comum encontrar os myomiRs com a expressão anormal em decorrência de processos patológicos que levem a injurias no músculo esquelético, pois esses microRNAs controlam a miogênese, morfologia e função muscular (Horak, Novak, \& Bienertova-Vasku, 2016).

Por outro lado, evidências acumuladas nos últimos anos mostram que o exercício físico provoca profundas adaptações no músculo esquelético, inclusive em condições patológicas. Uma das mais marcantes é a normalização 
do equilíbrio entre a síntese e a degradação de proteínas no miócito esquelético (CUNHA et al., 2012). Sabe-se, também, que o exercício físico tem um papel importante na regulação da expressão de diversos microRNAs. E devido a sua ação restauradora na expressão de diversos microRNAs alterados presentes em diferentes doenças, ele tem potencial terapêutico (Fernandes, Magalhães, Roque, Phillips, \& Oliveira, 2012; Janssen et al., 2013; Jopling, Yi, Lancaster, Lemon, \& Sarnow, 2005). Estes conhecimentos dão sustentação para a presente proposta em que pretendemos responder as seguintes perguntas: 1) os microRNAs circulantes expressos no câncer estão relacionados com o fenótipo muscular esquelético? 2) $O$ treinamento físico altera a expressão dos micr

oRNAs circulantes que são expressos no câncer, especificamente os myomiRs?

\section{Objetivos}

Analisar se há alteração na expressão dos myomiRs na musculatura esquelética e na circulação de animais com câncer comparados com animais saudáveis. Ainda, investigar os efeitos do treinamento físico aeróbico sobre a expressão deste myomiRs e sua relação com melhoras no massa e função muscular dos animais com câncer.

\subsection{Objetivos específicos}

As seguintes hipóteses foram testadas em dois diferentes modelos de câncer MMTV (não caquético) e CT26 (caquético):

- O câncer provoca alteração na expressão dos myomiRs-1, 133 a/b, 206, e 486 na circulação e no tecido muscular esquelético;

- As alterações nos myomiRs 1, 133a/b, 206, e 486 influenciam o balanço de síntese e degradação proteica nos miócitos esqueléticos através do aumento das vias de degradação relacionadas as proteínas PTEN (do inglês phosphatase and tensin homolog) e FOXO1 (do inglês forkhead box 01) e da diminuição das vias de síntese relacionadas as proteínas AKT (do inglês protein kinase B) e PI3K (do inglês phosphatidylinositol-4,5-bisphosphate 3kinase) 
- As alterações moleculares resultam em diminuição na função muscular;

- O treinamento físico normaliza a expressão dos myomiRs $1,133 \mathrm{a} / \mathrm{b}$, 206, e 486 na circulação e no músculo esquelético e, com isso, o balanço entre a síntese e a degradação de proteína muscular;

\section{Justificativa}

O câncer é um dos maiores problemas de saúde pública no Brasil e no mundo e sua taxa de mortalidade é alarmante (INCA, 2017). Ainda pouco se sabe sobre os efeitos do câncer na secreção de microRNAs específicos do músculo esquelético e a sua capacidade de alterar a expressão destes microRNAs e, com isso, provocar alterações morfológicas e bioquímicas no músculo esquelético e em outros tecidos. Por outro lado, já é bem estabelecido na literatura o papel do exercício físico em alterar a expressão dos microRNAs específicos do músculo esquelético. É sabido que o exercício físico tem um papel terapêutico em diversas outras patologias, entretanto ainda são poucos os estudos que mostram que o exercício físico aeróbico tem um potencial terapêutico também para a melhora do massa e função muscular em animais com câncer.

\section{Revisão de literatura}

\subsection{Câncer}

O câncer é conhecido há centenas de anos, os antigos egípcios já apresentavam registros dessa doença como também as civilizações subsequentes. Entretanto o câncer é uma doença que geralmente ocorre tardiamente na vida do indivíduo, dessa forma até o século XIX, período em que a expectativa de vida começou a aumentar mais significativamente, 0 número de pessoas que sobreviviam até apresentar câncer era relativamente baixo. No momento atual as doenças infectocontagiosas são controladas e algumas delas foram erradicadas, houve um aumento da população mais velha, levando a uma alta incidência de doenças crônicas e degenerativas, incluindo o câncer. (revisto em: Mukherjee, 2010).

O crescimento na incidência do câncer somado ao raso entendimento que temos sobre a doença torna-o um grande problema de saúde pública e um 
grande desafio para a ciência. Em 1990, Franks e Teich relataram no livro "Introdução a Biologia Celular e Molecular do Câncer":

O câncer ocupa um lugar estranho na mitologia moderna. Embora seja uma doença comum e seja certo dizer que uma em cada cinco pessoas morre de câncer, é igualmente certo afirmar que quatro em cinco morrem de outras doenças. Doenças cardíacas, por exemplo, causas muito mais comuns de morte, não parecem se associar ao diapasão de mau agouro, nem sempre justificado, do diagnóstico de câncer. Esta situação parece advir, em grande parte, do fato de que conhecemos muito pouco de uma doença que parece surgir quase ao acaso e se desenvolver inexoravelmente. (L. M. Franks \& N. Teich,1990 página 16.)

Mais de duas décadas depois, o câncer ainda tem esse "papel estranho na mitologia moderna", muito embora as pesquisas acerca do assunto tenham avançado sobremaneira, os tratamentos para a doença progrediram e novas terapias vem sendo propostas frequentemente (Siegel et al., 2013).

O câncer é caracterizado como um conjunto de doenças que tem um caráter crônico, degenerativo e progressivo. Essas doenças têm em comum um crescimento desordenado de células que invadem os tecidos e órgãos alvo e pode se espalhar para lugares distintos do corpo, através de um processo denominado metástase (Instituto Nacional De Câncer José Alencar Gomes Da Silva - INCA, 2017; National Cancer Institute - NCI, 2017). Essas células apresentam uma alta velocidade de divisão e acúmulo de mutações, a aglutinação dessas células determina a formação dotumor maligno. Essa característica maligna do câncer se diferencia de tumores benignos, que tem propriedades autolimitadas em seu crescimento, não invadem tecidos adjacentes, apresentam um crescimento lento e raramente apresentam risco a vida. Existem mais de 100 diferentes tipos de câncer e eles correspondem aos diversos tipos de células presentes nos tecidos e órgãos. Dessa forma os tipos de câncer são diferentes entre si (INCA; NCI 2017).

O câncer é uma das principais causas de morte no mundo, sendo que 14,1 milhões de adultos no mundo foram diagnosticados com câncer em 2012 e desse total 8,2 milhões (54\%) de pessoas morreram em decorrência da doença. Esse valor corresponde a $22 \%$ do total de mortes por doenças não 
infecciosas (WORLD HEALTH ORGANIZATION - WHO, 2016). Mais de 60\% do total de novos casos de câncer ocorrem na África, Ásia e América Central e do Sul. Essas regiões são responsáveis por $70 \%$ das mortes por câncer no mundo (WHO, 2016).

Existem diversas causas de câncer, podendo ser extrínsecas (ambientais) ou intrínsecas ao organismo. Muito embora as causas extrínsecas e intrínsecas possam estar inter-relacionadas. As causas ambientais estão associadas a hábitos do ambiente social e cultural e as causas internas, na sua maioria, são de origem genética e estão relacionadas com a capacidade do organismo de se defender de agressões ambientais, podendo ser adquiridas através de erros na replicação do DNA ou serem geneticamente herdadas. Esses fatores interagem entre si, aumentando a possibilidade da transformação maligna de células normais (INCA, 2016). Entretanto, a maioria dos tipos de câncer estão associados aos fatores ambientais, segundo WHO 2016 cerca de $30 \%$ das mortes por câncer são devido aos cinco principais riscos comportamentais e alimentares: alto índice de massa corporal, baixa ingestão de frutas e legumes, falta de atividade física, tabagismo e uso de álcool. Existem, ainda, outros fatores de risco ambientais cancerígenos, como exposição excessiva ao sol e trabalho em indústrias químicas, mas muitos fatores ainda não são inteiramente conhecidos (WHO, 2016).

O surgimento do câncer depende do tempo de exposição aos agentes carcinogênicos e quanto maior a exposição, maior a chance de acontecerem alterações celulares, pois existe uma interação entre o genoma e os carcinogênicos que gera anomalias no material genético das células fazendo com que elas apresentem um comportamento danoso. As anomalias nas células cancerosas estão relacionadas com o aumento da expressão de genes promotores de neoplasia (oncogenes) e a diminuição da expressão de genes supressores de neoplasia (antioncogenes) (Hanahan \& Weinberg, 2011; Lago, Sung, Ma, Wang, \& Hwang, 2011; Weinberg, 1989; Zimmers, Fishel, \& Bonetto, 2016).

O comportamento das células cancerosas varia de acordo com o tipo e câncer e tempo de desenvolvimento da doença, dessa forma as células não são homogêneas entre si sendo um dos motivos das dificuldades do 
entendimento e tratamento do câncer. Entretanto Hanahan e Weinberg (Hanahan \& Weinberg, 2011) descreveram algumas características comuns da maioria destas células no reconhecido trabalho "hallmarks of cancer: the next generation" publicado na revista Cell no ano de 2011. Os autores dizem que os tumores são mais do que um aglomerado de células cancerosas, eles são um tecido complexo formando por diversas células de diversos tipos que agem sinergicamente entre si. Os autores propõem que os diversos tipos de tumores apresentam certas características notáveis que contribuem para o desenvolvimento, progressão e malignidade da doença.

A primeira das características destacadas; é capacidade de manter sinais de proliferação de forma sustentada. Os tecidos normais controlam cuidadosamente a liberação de fatores de crescimento e proliferação, assim regulando o ciclo celular e assegurando a arquitetura e função adequada do tecido. Entretanto as células cancerosas apresentam esses sinais de proliferação descompensados não respeitando os controles do ciclo celular levando a uma proliferação celular exacerbada sem a preservação do arranjo morfológico e da função do tecido.

Ainda são pouco conhecidos todos os fatores que levam as células normais passarem a liberar sinais de proliferação descontroladamente ao passo de gerar tumores. Algumas mutações são bastante conhecidas como 0 gene PIK3CA (fosfatidilinositol-4,5-bifosfato 3-quinase subunidade catalítica alfa) relacionado à proliferação, crescimento e comumente observado em diversos tipos de canceres de mama (Anderson, Rosenberg, Prat, Perou, \& Sherman, 2014), além disso mutações em tirosinas quinases são as causas mais prováveis para as células expressarem de forma sustentada sinais de proliferação e iniciar a tumorigênese.

Outra característica notável é a capacidade das células cancerosas evadirem a sinais supressores de crescimento; essa segunda característica apresenta uma forte relação com a primeira. As células cancerosas também devem contornar programas robustos que regulam negativamente a proliferação de células; muitos destes programas dependem das ações de genes supressores de tumores. Proteínas RB e P53 são os dois supressores tumorais mais conhecidos e de maior atividade comprovada, eles controlam a 
proliferação, senescência e os programas apoptóticos celulares (Lago et al., 2011). Comumente células cancerosas apresentam prejuízos na expressão ou função dessas duas proteínas possibilitando o crescimento desenfreado.

A resistência à morte celular é mais uma das características notáveis, o conceito de que a morte celular programada por apoptose serve como uma barreira natural para o desenvolvimento de câncer foi estabelecida por estudos funcionais convincentes realizados ao longo das últimas duas décadas. A apoptose é desencadeada em resposta a várias tensões fisiológicas que as células cancerosas são submetidas no decurso de tumorigênese ou como um resultado de terapia antineoplásicas. No entanto, essa característica é atenuada nos tumores que conseguem progredir para estados de malignidade e resistem à terapia (Hanahan \& Weinberg, 2011).

As células cancerosas apresentam um potencial replicativo ilimitado e isso gera a possibilidade de ocorrerem tumores macroscópicos. Esta capacidade contrasta com o comportamento das células normais, a maioria delas são capazes de passar por apenas um número limitado de ciclos de crescimento e divisão celular (Hanahan \& Weinberg, 2011).

A indução de angiogênese é outra característica notável; como em qualquer tecido a presença de vasos permite a captação de nutrientes e oxigênio e a liberação de substancias não mais uteis para as células, no tumor não é diferente. Entretanto em tecidos adultos normais a angiogênese ocorre de forma temporária em resposta a algum estímulo como cicatrização e o clico reprodutivo feminino, mas é um processo transiente. Já no tumor esse processo passa a ser sustentado e novos vasos passam a surgir continuamente o que ajuda a promover o crescimento do tumor (Hanahan \& Weinberg, 2011).

Invasão e metástase também é uma característica destacada. Esta por sua vez é uma das mais importantes senão a de maior relevância, pois as maiores causas de morte em decorrência do câncer estão associadas à formação de metástases. A metástase é caracterizada como a formação de uma nova lesão tumoral que se origina do tumor primário. Este é um processo complexo onde a célula do tumor primário se desprende e ganha vias de 
circulação (sanguínea ou linfática), dessa forma se disseminando e formando colônias em locais distantes do tumor primário (Waning et al., 2015).

Essas células para chegar na circulação e para invadir tecidos distantes precisa modificar sua configuração; a transição epitélio-mesenquima é um fenômeno onde ocorre essa modificação celular, as células de características epiteliais desativam os mecanismos de adesão celular e adquirem propriedades locomotoras, dessas forma elas se tornam capazes de infiltrar 0 estroma e ter acesso aos vasos sanguíneos e linfáticos (Peinado et al., 2012; Yuan et al., 2014). Para que ocorra a metástase é preciso que haja também a preparação do "nicho metastático", o tecido que será invadido passa a ser preparado para receber as células cancerosas antes mesmo da sua chegada e para que isso ocorra é necessária uma intrincada sinalização celular que ocorre em nível sistêmico (Kaplan et al., 2005).

\subsection{Câncer e músculo esquelético}

O músculo esquelético representa um dos mais abundantes tecidos do corpo humano, chegando à aproximadamente $40 \%$ do peso corporal de humanos adultos. Esse tecido apresenta diversas funções tais como sustentação, movimento articular e produção de calor, além do fato de ser um tecido de extrema plasticidade e de fácil adaptação à diversos estímulos como nutricionais, mecânicos e humorais. O músculo esquelético também apresenta um papel fundamental na regulação dos depósitos de glicogênio, gasto energético e na atividade física (Ahima \& Park, 2015). Recentemente, o músculo esquelético vem sendo profundamente estudado, pois evidências acumuladas mostram que esse tecido tem um importante papel endócrino. Diversos trabalhos mostram a capacidade do músculo esquelético em produzir fatores humorais que promovem comunicação com outros órgãos; as proteínas e peptídeos responsáveis por essa comunicação são denominadas myokines (Ahima \& Park, 2015)(Schnyder \& Handschin, 2015).

Atualmente é muito claro que diversas doenças, principalmente as doenças crônicas metabólicas, causam danos ao músculo esquelético (Groarke, Cheng, Jones, \& Moslehi, 2013; Nicoletti, Zanolla, Brighetti, \& Zaedini, 2003; Tisdale, 2009). Mas é importante dizer que esses danos ao 
músculo esquelético levam ao agravamento das doenças, formando assim um ciclo vicioso, por exemplo, a caquexia do câncer, assunto que trataremos na próxima seção.

O músculo esquelético é composto de fibras que são classificadas de acordo com a sua velocidade de contração e tipo predominante de metabolismo energético. As fibras musculares podem ser classificadas como tipo I, de contração lenta e tipo II, de contração rápida e com base no conteúdo dominante da sua isoforma de miosina de cadeia pesada. Geralmente, fibras do tipo I utilizam predominantemente a fosforilação oxidativa como sua fonte principal de energia, enquanto fibras do tipo Ilx e llb aproveitam-se do metabolismo anaeróbico para gerar ATP e fibras do tipo lla utilizam ambos os metabolismos. Tanto a porcentagem e morfologia estrutural do tipo de fibra vai determinar a capacidade fenotípica e o desempenho funcional de um determinado músculo. Os fatores ambientais, tem um impacto direto na musculatura levando a mudanças no tipo de fibra e morfologia que levam a alterações na funcionalidade muscular; tais processos incluem a idade, exercício, diabetes, atrofia por desuso, insuficiência cardíaca crônica e a caquexia (Johns, Stephens, \& Fearon, 2013).

Grande parte dos tipos de câncer geram alterações sistêmicas e afetam as expressões moleculares, metabólicas e fenotípicas de outros órgão e tecidos, incluindo o músculo esquelético. As neoplasias levam ao aumento da expressão de citocinas inflamatórias, alterações na expressão de hormônios sexuais, diminuição dos adipócitos e alterações na expressão de diversas proteínas, por exemplo, diversos tipos de cânceres levam a diminuição da fosforilação da mTOR no músculo esquelético, uma importante proteína da via de síntese proteica, aumento de fosforilação de fatores do fator de tradução proteica elF2-alfa (fator de iniciação eucariótico 2) e o aumento da expressão de 4EBP1 (do inglês eukaryotic translation initiation factor 4E-binding protein 1), um repressor da tradução proteica (Groarke et al., 2013; Tisdale, 2009). Além desse desbalanço, a literatura também sugere que as disfunções na musculatura esquelética de indivíduos com câncer podem ter prejuízo no complexo glicoproteínas-sarcoglicanas e, dessa forma, se assemelhando as disfunções de indivíduos distróficos (Acharyya et al., 2005). 
Entretanto os mecanismos de perda de massa e função muscular em decorrência do câncer ainda são pouco conhecidos, sabe-se até o momento que os modelos animais utilizados para os estudos da caquexia do câncer diferem-se entre si; dependendo do tipo de câncer há um aumento nas vias de degradação através do sistema ubiquitina proteassoma acompanhado com a diminuição da síntese proteica. Este é o modo mais simples de pensar na perda de massa muscular pois há um incremento da degradação e um decréscimo da síntese, entretanto essas vias não são ativadas do mesmo modo em todos os modelos, os mediadores chave dessas vias são pouco conhecidos e, somado a isso, os modelos murinos apresentam uma progressão do quadro de caquexia que é muito mais rápida e dessa forma diferente do que acontece em seres humanos (Johns et al., 2013).

\subsubsection{Câncer e caquexia}

Há mais de 100 anos Willian Osler descreveu a caquexia do câncer, naquele momento um fenômeno observado em pacientes com câncer de estomago, como um emagrecimento progressivo somado a perda de força desproporcional a perda de peso (Chaun, 2010). Atualmente a caquexia é conhecida como uma síndrome multifatorial caracterizada por uma perda contínua de peso, que não pode ser revertida pelo suporte nutricional convencional, levando a uma deficiência funcional progressiva. Esta síndrome é importante pois ela acarreta na diminuição da capacidade funcional, qualidade de vida, a resposta ao tratamento do câncer e mau prognóstico da doença (Groarke et al., 2013; Johns et al., 2013).

A caquexia é uma síndrome comum em pacientes com doenças oncológicas avançadas e severas, independentemente do tipo de câncer, apesar de alguns tipos de canceres favorecerem o desenvolvimento da síndrome, esta por sua vez é responsável por aproximadamente $20 \%$ das mortes por câncer (Groarke et al., 2013).

A perda de peso na caquexia do câncer se dá pela diminuição da massa muscular esquelética e do tecido adiposo o que gera um importante desbalanço no consumo energético. $O$ tecido adiposo na caquexia apresenta aumento severo da lipólise ocasionada pela expressão anormal diversas 
enzimas tais como de adenil ciclase, o aumento de epinefrina, e o aumento da transformação de tecido adiposo branco em bege (browning). O músculo esquelético apresenta exacerbadas sinalizações de degradação proteica e apoptose desencadeadas pelo aumento de proteínas como atrogin, MURF (do inglês muscle ring-finger protein) e FOXO responsáveis pela degradação muscular e aumento de miostatina somado a diminuição de IGF e PI3K que por sua vez diminui a síntese proteica. Curiosamente, nos indivíduos caquéticos pode ocorrer o desenvolvimento de anorexia que potencializa a perda de peso e principalmente de massa muscular gerando um ciclo vicioso no balanço energético descompensado. O tumor por sua vez lança diversos fatores de sinalização para os demais tecidos dentre eles o músculo esquelético e 0 tecido adiposo, ocorre um aumento da expressão de citocinas inflamatórias tais como TNF- $\alpha$ (fator de necrose tumoral) e inteleucina-1 e interleucina- 6 que contribuem para a perda de massa desses tecidos (Tisdale, 2009).

\subsection{MicroRNAs}

Os microRNAs são uma classe de moléculas que vem sendo largamente estudadas nas últimas duas décadas por terem o importante papel de regular a expressão de proteínas, mesmo após a transcrição do RNA mensageiro (mRNA).

Estes são caracterizados como pequenos RNAs de fita curta de aproximadamente 17 a 22 nucleotídeos, que não codificam proteínas e atuam se ligando ao mRNA reprimindo a tradução de proteínas, os mesmos são encontrados em diversos organismos como animais e plantas (Horak, Novak, \& Bienertova-Vasku, 2016). Os microRNAs controlam diversos processos tanto fisiológicos como patológicos; há evidências que ao menos um terço de todas as vias biológicas sofrem controle por microRNAs.

Essa classe de moléculas foi observada pela primeira vez em 1993 por Lee e seus colegas, o primeiro microRNA conhecido foi o lin-4, este está associado ao desenvolvimento larval de $C$ elegans (Lee, Feinbaum, \& Ambros, 1993), entretanto as pesquisas com microRNA só passaram a progredir depois dos anos 2000, onde foi observado que esse mesmo microRNA lin-4 participava do controle pós transcricional da proteína lin-14 (Hong, Lee, \& 
Ambros, 2000), através da ligação complementar do microRNA com a região 3'UTR do mRNA da proteína. Outros estudos foram desenvolvidos para testar a hipótese de que pequenos RNAs poderiam participar dos controles pós transcricionais, quando, portanto, foi descoberto o microRNA let-7, que apresenta uma ligação parcialmente complementar com a região 3'UTR do mRNA da proteína lin-41 e também exerce controle negativo sobre a expressão proteica (Ambros, 2001). Esses achados possibilitaram descobertas de novos microRNAs e atualmente são conhecidas mais de 30.000 sequências de microRNAs maduros nos mais diferentes organismos (Horak et al., 2016).

Como dito, os microRNAs exercem sua ação através da ligação com a região 3'UTR do mRNA alvo. Essa ligação pode ser com total complementariedade ou parcial, isso indicará se o mRNA será degradado ou se sua tradução será apenas inibida. Com a complementariedade total ocorre a degradação dos mRNAs, esse fenômeno depende de um pareamento perfeito dos pares de base entre o microRNA e o mRNA e é mais comumente observado em plantas. Nos mamíferos há uma complementariedade parcial levando a inibição da tradução do alvo; os microRNAs se ligam a uma região do mRNA denominada seed presente na região 3'UTR onde apenas alguns dos pares de base são complementares, mas o bastante para haver ligação. Devido a esse pareamento imperfeito e o pequeno tamanho dessas moléculas existe a possibilidade de um microRNA apresentar diversos alvos (Ambros, 2001; Hong et al., 2000; Horak et al., 2016; van Rooij, Purcell, \& Levin, 2012).

A biogênese dos microRNAs se dá através da ação da enzima RNA polimerase II que gera um transcrito denominado pri-microRNA, entretanto para se chegar na forma madura este ainda precisa passar por uma série de clivagens. O pri-microRNA apresenta uma estrutura de dupla hélice do tipo hairpin e aproximadamente 300 nucleotídeos; ainda no núcleo celular a enzima Drosha cliva este transcrito formando um precursor do microRNA chamando pré-microRNA, este por sua vez é exportado para o citoplasma pela enzima exportina 5. No citoplasma o pré-microRNA é clivado pela enzima Dicer, esse processo dá origem a um duplex de RNA, ou seja, duas fitas em conjunto, uma delas é o microRNA maduro e a outra é denominada de anti-sense. $O$ microRNA maduro é então incorporado por um complexo multimérico de nome 
RISC (RNA induced silencer complex) enquanto a outra fita pode ser degradada ou se ligar, também, a outro complexo RISC (Horak et al., 2016) (um diagrama esquemático pode ser encontrado na figura 1).

Recentemente os microRNAs vem ganhando um papel ainda mais importante, pois eles podem ter um papel paracrino e promover a comunicação entre tecidos. Em 2007 foi descrito pela primeira vez que um tipo especifico de microRNA de uma dada célula pode ser transfectado em uma outra célula totalmente distinta e apresentar a mesma função. Em 2008 foi descoberta a presença dos microRNAs no plasma e em outros fluidos biológicos, e esses dados ajudaram a concluir que os microRNAs são viáveis no meio extracelular e podem ser importantes moléculas sinalizadoras. Desde então os microRNAs circulantes tem sido largamente estudados, pois os mesmo apresentam características até então pouco descritas, por exemplo, podem ser sinalizadores de célula-célula e dessa forma influenciar uma vasta gama de processos biológicos. Os microRNAs circulantes são encontrados em quase todos os fluidos biológicos dentre eles leite, plasma, soro, saliva, urina, lágrima e líquido amniótico (Creemers, Tijsen, \& Pinto, 2012).

Os microRNAs circulantes são altamente estáveis e são resistentes a RNAses, congelamento e variações do $\mathrm{pH}$, essa estabilidade está associada com os transportadores que carreiam essas moléculas; podendo ser diferentes vesículas secretadas pelas células, por exemplo exossomos; carreados por HDL ou proteínas argonautas (família de proteínas que desempenham um papel central no processo de silenciamento de RNAs, as proteínas desta família funcionam como componentes catalíticos essenciais do complexo silenciador induzido por RNA (RISC); dessa forma os microRNAs se ligam nesses proteínas, dessa forma corpos apoptóticos com presença dessas proteínas podem carrear microRNA para fora das células), essa provavelmente é a maior forma de concentração de microRNAs circulantes, entretanto é uma forma não funcional servindo apenas como biomarcadores (Creemers et al., 2012). 


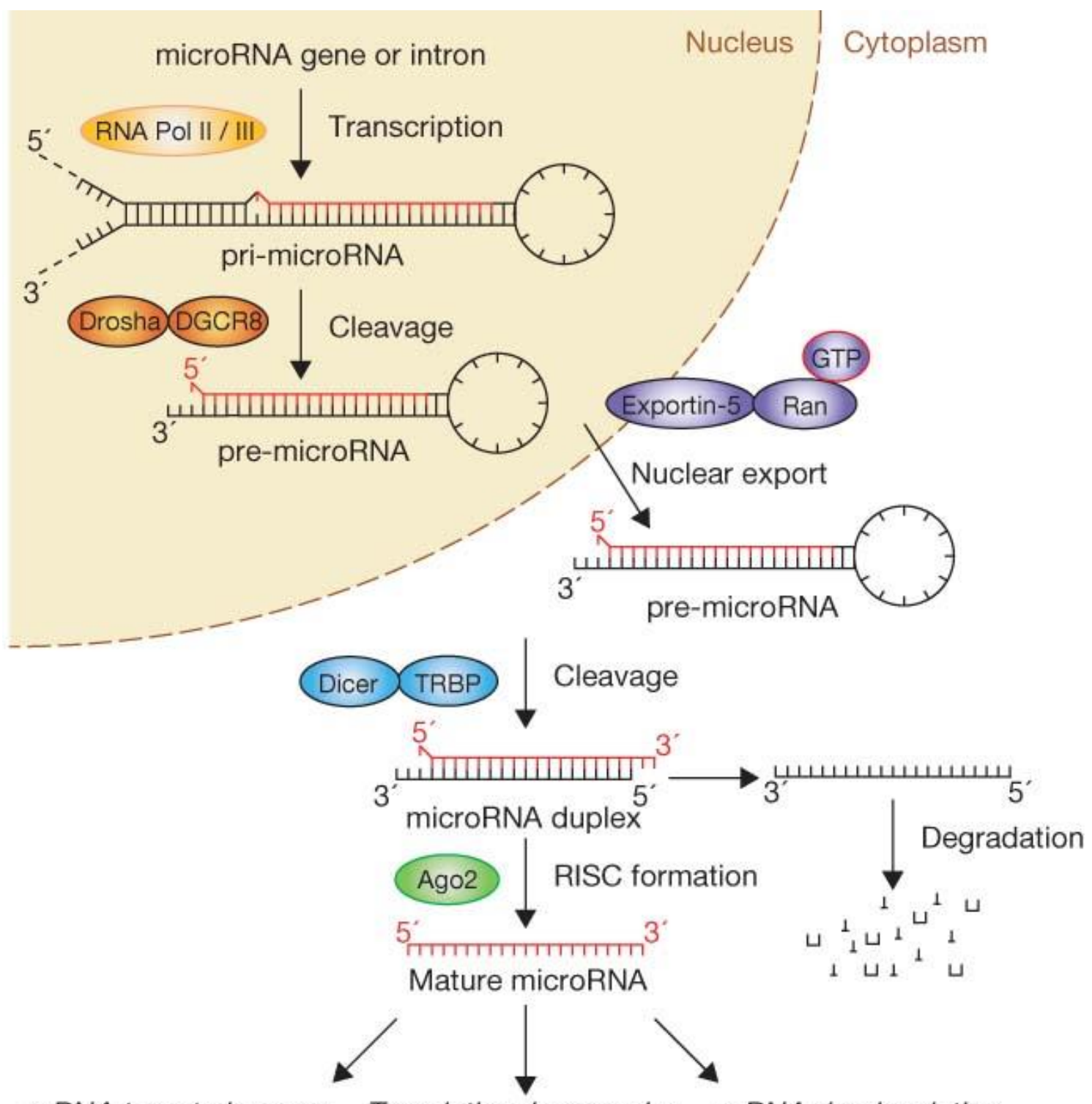

mRNA target cleavage Translational repression mRNA deadenylation

Figura 1: Biogênese dos microRNAs (Winter, Jung, Keller, Gregory, \& Diederichs, 2009)

\subsubsection{MyomiRs}

O músculo esquelético associado ao tecido cardíaco apresentam seu próprio conjunto de microRNAs, sendo estes os microRNA-1, microRNA 133a/b, microRNA -206, microRNA -208a/b, microRNA -486 e microRNA-499 que são denominados de myomiRs (Brown \& Goljanek-Whysall, 2015), porém cabe a ressalva que o microRNA-206 é expresso somente no músculo esquelético e o microRNA-208a é expresso somente no coração. Estes microRNAs controlam a biogênese e manutenção do tecido muscular (Horak et al., 2016). Em casos de doenças crônicas é comum encontrar a expressão 
anormal destes acompanhada por injúria no músculo esquelético e cardíaco. (Na tabela 1 está apresentado um sumário da função dos myomiRs)

Tabela 1: Sumario dos myomiRs; função e genes alvos. Adaptado de Horak et al.,2016.

\begin{tabular}{|c|c|c|}
\hline myomiRs & Função no músculo esquelético & Alvos no músculo esquelético \\
\hline microRNA-1 & $\begin{array}{l}\text { promoção de diferenciação de } \\
\text { mioblastos, regeneração, } \\
\text { angiogenese, pro-apoptose, anti- } \\
\text { migração. }\end{array}$ & $\begin{array}{l}\text { BDNF, CCND1, CCND2, FZD7, } \\
\text { G6PD, GJA1, HACD3, HDAC4, } \\
\text { HSPA1, IGF1, IGF1R, MAP4K3, } \\
\text { MEOX2, MET, MMD, NFAT5, } \\
\text { NOTCH3, PAX3, PAX7, POLA1, } \\
\text { RARB, SARS, SMARCB1, } \\
\text { SMARCD2, UTRN, VEGFA, YY1 }\end{array}$ \\
\hline microRNA-206 & $\begin{array}{l}\text { promoção de diferenciação de } \\
\text { mioblastos, regeneração, anti- } \\
\text { angiogenese, pro-apoptose, anti- } \\
\text { migração, remodelação da cromatina. }\end{array}$ & $\begin{array}{l}\text { BDNF, CCND1, CCND2, CLCN3, } \\
\text { FSTL1, FZD7, G6PD, GJA1, } \\
\text { HACD3, HDAC4, HMGB3, IGF1, } \\
\text { IGFBP5, MAP4K3, MEOX2, MET, } \\
\text { MMD, NFAT5, NGFR, NOTCH3, } \\
\text { PAX3, PAX7, POLA1, RARB, } \\
\text { SH3BGLR3, SMARCB1, } \\
\text { SMARCD2, SNAI2, TIMP3, UTRN, } \\
\text { VEGFA }\end{array}$ \\
\hline microRNA-133a & $\begin{array}{l}\text { promoção de proliferação, } \\
\text { diferenciação e fusão de mioblastos, } \\
\text { regulação de splicing alternativo, } \\
\text { remodelamento da cromatina, pro- } \\
\text { apoptótico, controle do metabolismo } \\
\text { de mitocondrias, alteração nos tipos } \\
\text { de fibras musculares. }\end{array}$ & $\begin{array}{l}\text { CALM1, DNM2, FGFR1, FOXL2, } \\
\text { IGF1R, MAML1, PFN2, PP2AC, } \\
\text { PRDM16, PTBP2, RUNX2, } \\
\text { SMARCD1, SP1, SRF, TRPS1, } \\
\text { UCP2, }\end{array}$ \\
\hline microRNA-133b & $\begin{array}{l}\text { promoção de proliferação, } \\
\text { diferenciação e fusão de mioblastos, } \\
\text { regulação de splicing alternativo, } \\
\text { remodelamento da cromatina, pro- } \\
\text { apoptótico. }\end{array}$ & $\begin{array}{l}\text { FAIM, FGFR1, MAML1, PP2AC, } \\
\text { PRDM16, PTBP2, SP1, BDNF }\end{array}$ \\
\hline microRNA-208b & $\begin{array}{l}\text { alteração nos tipos de fibras } \\
\text { musculares, promoção de crescimento } \\
\text { celular. }\end{array}$ & $\begin{array}{l}\text { CBX1, MED13, MSTN, PURB, } \\
\text { SOX6, SP3 }\end{array}$ \\
\hline microRNA-486 & $\begin{array}{l}\text { promoção de proliferação e fusão de } \\
\text { mioblastos, regulação de splicing } \\
\text { alternativo, anti-apoptotico e pro- } \\
\text { migração. }\end{array}$ & $\begin{array}{l}\text { DOCK3, FOXO1, PAX7, PDGFRB, } \\
\text { PTEN, SRSF1, SRSF3, CBX1 }\end{array}$ \\
\hline microRNA-499 & $\begin{array}{l}\text { alteração nos tipos de fibras } \\
\text { musculares, promoção de crescimento } \\
\text { celular. }\end{array}$ & $\begin{array}{l}\text { CBX1, MAPK6, MED13, MSTN, } \\
\text { PURB, SOX6, SP3 }\end{array}$ \\
\hline
\end{tabular}




\subsection{MicroRNA e câncer}

Muitos trabalhos mostram a participação dos microRNAs nos diversos tipos de câncer. A literatura aponta que os microRNAs tem uma expressão alterada em diversos tipos de câncer e muitos estudos estão sendo conduzidos com essa classe de moléculas para elucidar seu papel no controle da fisiopatologia do câncer (KODAHL et al 2014; MÜLLER et al, 2014, TUTAR, 2014).

Evidências mostram que os microRNAs participam nos processos citado como hallmarks do câncer ((Hanahan \& Weinberg, 2011) e que o fenótipo do câncer pode ser modificado através da expressão de microRNAs (Yuan et al., 2014). Baseado nessa observação existe um esforço da comunidade cientifica em compreender melhor os mecanismos envolvendo microRNA e câncer, que por sua vez são extremamente intrincados, para desenvolver terapias gênicas específicas (Garzon, Marcucci, \& Croce, 2010). Os objetivos dessas terapias são promover melhores respostas as drogas convencionais para o tratamento da doença e reprimir de modo especifico processos oncogênicos agindo como um tratamento e melhorando o prognóstico da doença.

Estudos de ganho e perda de função têm sido desenvolvidos para maiores entendimentos sobre o papel dos microRNAs. Por exemplo, em um estudo de Garzon e seus colegas foi observado que há um decréscimo da expressão dos microRNAs-15a/16 em pacientes com leucemia linfoide crônica, esse comportamento era também observado em células CLL23 que modulam o mesmo tipo de câncer. Dessa forma os pesquisadores aumentaram de modo ectópico a expressão destes microRNAs nas células leucêmicas e investigaram os processos de proliferação e apoptose. O trabalho observou que com a super expressão dos microRNAs $15 \mathrm{a} / 16$ nas células CLL23 gera um aumento da apoptose e menor proliferação, esse fato se dá pois os microRNAs alvejam a proteína BCL-2 um importante fator anti-apoptótico; essa proteína é reconhecidamente aumentada em pacientes com a doença (Garzon et al., 2010).

Em contraste os microRNAs podem estar aumentados no câncer e seus efeitos biológicos podem ser potencializados pelo câncer tornando-os 
deletérios. É o caso do microRNA-21, que sua alta expressão é observada em glioblastomas, câncer de pâncreas, mama e câncer de colón. Um ensaio de perda de função mostrou que o bloqueio desse microRNA em células de glioblastoma foi capaz de aumentar a atividade de caspases e promover apoptose. Uma possível explicação para tal é que esse microRNA alveja a proteína PTEN e a proteína PDCD4 ( do inglês programmed cell death) funcionando nesse caso como uma agente anti-apoptótico no câncer (Chan, Krichevsky, \& Kosik, 2005).

Além disso os microRNAs estão envolvidos em diversos outros fatores do câncer como por exemplo na formação de metástases; como no estudo de Zhou e seus colegas onde foi observado que o microRNA-105 prepara o "nicho metastático" destruindo as barreiras endoteliais e aumento a permeabilidade dos vasos. Isso ocorre em animais com câncer de mama que apresentam altos níveis de expressão deste microRNA que tem como alvo proteínas de adesão celular, principalmente a proteína ZO-1. O bloqueio da expressão desse microRNA nesse animais impede o desenvolvimento de metástases (Zhou et al., 2014).

Os microRNAs também são vistos como biomarcadores para alguns processos que ocorrem nos diferentes tipos de câncer, é o caso do microRNA 200c, ele é visto como um marcador de bom prognóstico do tratamento da neoplasia de mama. Este microRNA é facilmente detectado na circulação, mas em casos de ausência desse microRNA é um dos primeiros indícios que o indivíduo está em formação de metástase (Shao et al., 2015). Esse microRNA tem um importante papel de repressão de proteínas que promovem a transição epitélio mesenquima, entretanto ele compete com sitio de ligação de um importante long non-conding RNA (uma classe de RNAs não codificadores de proteínas que desempenham também papel de controle pós transcricional) denominado ATB, e a ligação do microRNA com o ATB permite a maior expressão dessas proteínas que auxiliam na promoção da metástase (Yuan et al., 2014).

O trabalho de Chen e colaboradores evidencia que 34 microRNAs estão diferentemente expressos no soro sanguíneo de camundongos com câncer de mama MMTV-PyMT. O estudo, entre os microRNAs diferencialmente 
expressos, escolheu estudar a expressão do microRNA 486, pois este estava severamente diminuído na circulação e essa diminuição sistêmica era acompanhada da diminuição no tecido muscular esquelético e cardíaco. Como dito anteriormente, esse microRNA regula a expressão de proteínas que controlam a degradação proteica como PTEN e a FOXO1a. O trabalho infere que existe uma relação entre a expressão do microRNA-486 circulante com a diminuição do mesmo nos músculos o que por sua vez gera diminuição na síntese proteica. Esse mesmo trabalho estudou a expressão do microRNA-486 em soro sanguíneo de humanos com câncer de mama e também encontrou uma diminuição na sua expressão. Dessa forma, o estudo sugere que pode haver uma atrofia muscular em indivíduos com câncer de mama causada pelas ações dos microRNAs (Chen et al., 2014).

\subsubsection{MicroRNA, câncer e músculo esquelético}

Pouco se sabe sobre o papel dos microRNAs sobre a caquexia do câncer. Apesar dos poucos estudos, existem evidências tanto in vitro quanto in silico que os microRNAs 21 e 206 geram atrofia muscular no câncer através da inibição do alvo YY1 (yin yang 1) um fator de transcrição para a síntese proteica (Soares et al., 2014).

He e seus colegas demonstraram que em indivíduos com câncer pancreático ocorre um notável aumento da expressão de PAX7 induzindo a proliferação de células satélites de modo anormal e diminuindo o processo de diferenciação da mesma; este processo resulta em atrofia muscular. Estes dados sugerem que o tumor influencia no microambiente muscular, e, como já citado, o processo de proliferação é orquestrado de forma extensiva por diversos microRNAs (W. A. He et al., 2013).

Outro trabalho de $\mathrm{He}$ e colaboradores demonstrou que exossomos ricos do microRNA-21 são encontrados na circulação de indivíduos com câncer de pâncreas e pulmão; quando mioblastos são tratados com esses exossomos ocorre uma interação da microvesícula com a célula muscular ocasionando em morte da mesma, porém esse processo só ocorre na presença da proteina TLR8 (do inglês Toll-like receptor 8) (W. a He et al., 2014). 


\subsection{Exercício Físico Aeróbico}

A literatura aponta que o exercício físico aeróbico, apesar de não ter um papel essencial em regular o trofismo e melhorar a força de indivíduos saudáveis, tem um importante papel na melhora do trofismo de indivíduos com prejuízos já existentes na massa muscular, por exemplo, sarcopênicos (Fernandes, Magalhães, Roque, Phillips, \& Oliveira, 2012).

Sendo assim, o exercício físico aeróbico é um importante fator para o remodelamento muscular esquelético. Além de regular o trofismo muscular e a força, o exercício físico aeróbico muda o perfil da distribuição das fibras musculares, influenciando, assim, o metabolismo e a função muscular tanto em indivíduos saudáveis quanto em indivíduos com doenças já existentes (Fernandes et al., 2012).

Vários trabalhos mostram o exercício físico aeróbico como um tratamento não farmacológico para diversas patologias como hipertensão, diabetes, osteopenias e cardiopatias (Roque, Hernanz, Salaices, \& Briones, 2013; Soci et al., 2011), pois o mesmo apresenta melhoras em diversos sistemas, uma vez que ele promove diminuição da ação do sistema nervoso autônomo simpático, auxilia no controle fisiológico de hormônios, promove angiogênese e melhora da função de diversos tecidos como o muscular cardíaco, vascular, ósseo entre outros (Roque et al., 2013).

\subsubsection{Câncer e Exercício Físico}

A literatura apresenta dados consistentes com humanos e animais em relação ao efeito protetor do exercício físico aeróbico contra o câncer de mama. $O$ estudo de Goh e colaboradores, mostra que ratos inoculados com tumor de mama (derivado da injeção de mammary fat pad $4 T 1$ tumor cells, que gera um tumor extremamente invasivo na mama) que foram submetidos ao treinamento físico aeróbico antes do desenvolvimento tumoral apresentaram menor volume do tumor (Goh, Niksirat, \& Campbell, 2014) em 2016 Pedersen e seus colaboradores evidenciaram o mesmo fenômeno em animais inoculados com melanoma B16 (Pedersen et al., 2016). 
Entretanto o efeito do uso do exercício físico aeróbico no tratamento dos diversos tipos de cânceres ainda é pouco claro. Um estudo realizado por Repka e colaboradores mostrou que a resposta ao exercício de indivíduos com câncer de mama, próstata e pulmão é positiva. Esses indivíduos apresentaram melhora na força, na capacidade aeróbia, na função cardiorrespiratória e na função pulmonar e, em consequência, houve um aumento da tolerância a fadiga (Repka et al., 2014). Outros estudos sugerem que o exercício físico aeróbico tem um importante papel, também, em melhorar a qualidade de vida dos indivíduos com câncer (Mishra, Scherer, Snyder, Geigle, \& Gotay, 2014). Esse resultado é importante, pois a literatura aponta que há uma diminuição da capacidade cardiopulmonar de indivíduos com câncer de mama (Peel, Thomas, Dittus, Jones, \& Lakoski, 2014).

\subsubsection{MicroRNA e exercício físico aeróbico}

Estudos apontam que o exercício físico aeróbico é capaz de modular a expressão de diversos microRNAs tanto teciduais como circulantes.

O trabalho de Baggish e colaboradores mostra que o exercício é capaz de aumentar a expressão de diversos microRNAs circulantes, que estão envolvidos com a diminuição de fatores inflamatórios, como os microRNAs-21 e miR-146a, e microRNAs que estão envolvidos com o trofismo e a contratilidade muscular cardíaca e muscular esquelética, como o microRNAs-133a (Baggish et al., 2014). Mooren e colaboradores também aponta que o exercício físico aeróbico altera a expressão dos microRNAs na circulação, e alguns microRNAs como o -206, - 1 e o -21 podem ser utilizados como biomarcadores do treinamento aeróbico (Mooren, Viereck, Kruger, \& Thum, 2014).

Ainda outros estudos mostram que o trofismo muscular esquelético é regulado pela a ação de determinados microRNAs, e o exercício é capaz de controlar a expressão desses microRNAs, por exemplo, os myomiRs. O principal alvo do microRNA-133 é o receptor de IGF-I, o IGF-IR; estudos realizados com células mostram que super-expressão ou knockdown de IGF-IR resulta na modulação da fosforilação da via PI3K-AKT. O microRNA-133 diminui a expressão do IGF-IR e, sendo assim, ele contribui diretamente para a diminuição da cascata de reações que levam a fosforilação da AKT, 
acarretando em decréscimos no desenvolvimento do músculo esquelético ( $\mathrm{Yu}$, Lu, Li, \& Wang, 2014). Ainda, sugere-se uma diminuição desse microRNA pelo exercício físico aeróbico (Safdar, Saleem, \& Tarnopolsky, 2016)

Muitos trabalhos na literatura mostram, também, que o exercício físico aeróbico tem a capacidade de controlar a expressão de diversos microRNAs que estão descompensados por doenças como hipertensão, diabetes e obesidade. Os estudos mostram que essas patologias causam alterações moleculares e estruturais e o exercício físico aeróbico é um estímulo positivo para a reversão e o controle dessas alterações deletérias como diminuição da massa muscular e rarefação microvascular. Portanto, o exercício físico aeróbico regula a expressão de microRNAs envolvidos com essas mudanças negativas, e restaura o tecido ou previne a deterioração acentuada (Fernandes et al., 2012).

\subsection{MicroRNA, câncer e exercício físico}

Poucos sãos os trabalhos que investigam o papel dos microRNAs relacionados com câncer e o exercício físico aeróbico.

Isanejad e seus colaboradores se baseando na premissa que 0 sedentarismo é um fator para o desenvolvimento de câncer e que o exercício físico crônico diminui a expressão de proteínas pró-inflamatórias tais como TNF- $\alpha$ e IL-1 a e somado ao fato do exercício físico diminuir a expressão do microRNA-21 desenharam um experimento com o objetivo de investigar o efeito de 5 semanas de treinamento aeróbico combinado com terapia hormonal para averiguar a expressão dos microRNAs-21, 206 e let-7 e o papel desses microRNAs na angiogênese do tumor em animais com câncer de mama. Os resultados encontrados no trabalho foram a diminuição do microRNA-21 e o aumento dos microRNAs 206 e let7 nos animais submetidos ao treinamento físico e a terapia hormonal, entretanto seus alvos diretos não foram confirmados, mas os pesquisadores afirmam que houve menor angiogênese no tumor acompanhado de diminuição de HIF-1a, CD31, Ki67 e VEGF (Isanejad et al., 2016).

Um outro estudo mostra que o exercício físico aeróbico também diminui a expressão do microRNA-21 em animais com câncer de mama, e o exercício 
associado a droga tamoxifeno diminuiu a tamanho do tumor e inibiu a proteína anti-apoptótica BCL2 (Khori et al., 2015).

Não existem estudos que mostrem que o câncer é capaz de alterar a expressão dos myomiRs e como essa alteração pode não só prejudicar a função e morfologia da musculatura esquelética, mas também causar mudanças deletérias no organismo como um todo. Sabe-se que o exercício físico modula a expressão dos myomiRs. Portanto, nós pretendemos entender se o câncer é capaz de alterar a expressão dos myomiRs e como essa alteração está relacionada com a função e morfologia do músculo esquelético, assim como, do organismo.

\section{Materiais e métodos}

\subsection{Desenho experimental}

Estudo 1: Como primeiro modelo, utilizamos uma linhagem de camundongos fêmeas transgênicos de câncer de mama chamada MMTVPуMT e seus controles saudáveis, esses animais foram provenientes do biotério da Faculdade de Medicina da Universidade de São Paulo. Os mesmos foram mantidos no biotério da EEFE-USP. Condicionados em gaiolas com 4 animais cada, sala climatizada de $22^{\circ}$ a $24^{\circ} \mathrm{C}$ e foi mantido o ciclo de claroescuro invertido. Água e comida foram administradas ad libitum. Os animais foram divididos em grupo controle saudável sedentário (SS), saudável treinado (STR), câncer sedentário (CS) e câncer treinado (CTR). O grupo SS apresenta $n=7$; STR $n=6$; CS $n=8 ;$ CTR $n=8$ (Figura 2).

Os grupos treinados realizaram atividade de corrida em esteira ao longo do protocolo.

$O$ treinamento foi realizado segundo o protocolo desenvolvido por Ferreira e seus colaboradores em sistema de esteira (Ferreira et al., 2007). O treinamento teve duração de 8 semanas para o modelo MMTV e 6 semanas para o modelo CT26 sendo 5 sessões semanais com aumento progressivo do tempo, chegando a 60 minutos, e aumento progressivo de sobrecarga de trabalho, chegando a $60 \%$ da velocidade máxima conseguida no teste de exaustão que corresponde a intensidade de máxima fase estável de lactato. 
Esse trabalho é caracterizado como de moderada intensidade com predomínio de metabolismo aeróbico.

Os animais foram identificados e pesados semanalmente para avaliar a progressão da massa corporal. Nas $7^{\circ}, 12^{\circ}$ e $16^{\circ}$ semanas de vida, eles foram submetidos a um teste de esforço máximo para adequação da carga de treinamento e avaliação da capacidade física. Para os grupos STR e CTR o protocolo de treinamento se iniciou na $8^{\circ}$ semana de vida dos animais e durou mais 8 semanas. No final do protocolo de treinamento, foram avaliados a função muscular e as respostas hemodinâmicas. Os animais foram sacrificados após 48 horas depois da última sessão de treinamento amostras biológicas foram coletadas e imediatamente congeladas em nitrogênio líquido, na sequência foram acondicionadas em $-80^{\circ} \mathrm{C}$.

Estudo 2: Utilizamos o modelo animal balb/c onde injetamos $1 \times 10^{6} \mathrm{de}$ células de câncer de colón CT26, os animais eram provenientes do biotério da EEFE-USP e as células cancerosas do Instituto de Câncer do Estado de São Paulo.

Os animais também foram divididos em grupo controle saudável sedentário (SS), saudável treinado (STR), câncer sedentário (CS) e câncer treinado (CTR). O grupo SS apresenta $n=12$; STR $n=5 ;$ CS $n=11$; CTR $n=8$.

Todos os cuidados com água, comida, número de animais por gaiola e ciclo de luz foi conduzido da mesma forma que o estudo 1.

O protocolo de treinamento iniciou na $8^{\circ}$ semana de vida dos animais e as injeções de células CT26 foram administradas na 120 semana para os grupos CS e CTR. Dessa forma os animais CTR permaneciam treinando livre do câncer por 4 semanas e depois da injeção eles ainda treinavam por mais 2 semanas (no protocolo original os animais deveriam treinar 8 semanas, entretanto se este fosse seguido os animais não sobreviveriam).

Também realizamos o protocolo de esforço máximo antes do início do protocolo de treinamento, um dia antes da injeção, uma semana após a injeção (7 dias com o tumor) e 2 dias antes da eutanásia (12 dias com o tumor) (Figura 3). 
No estudo 1 e 2 os animais foram distribuídos randomicamente nos grupos, utilizamos o teste de esforço máximo como medida de normalização. Os resultados encontrados nesse teste foram divididos em 4 grupos aleatoriamente pelo software Excel e na sequência realizamos análise estatística onde o p-valor deferia ser o mais próximo possível de 1.

Todos os procedimentos foram realizados de acordo com os Princípios Éticos de Experimentação Animal adotados pelo Colégio Brasileiro de Experimentação Animal e este projeto de pesquisa foi aprovado pelo Comitê de Ética da EEFE-USP, com o seguinte número de projeto 2015/03.

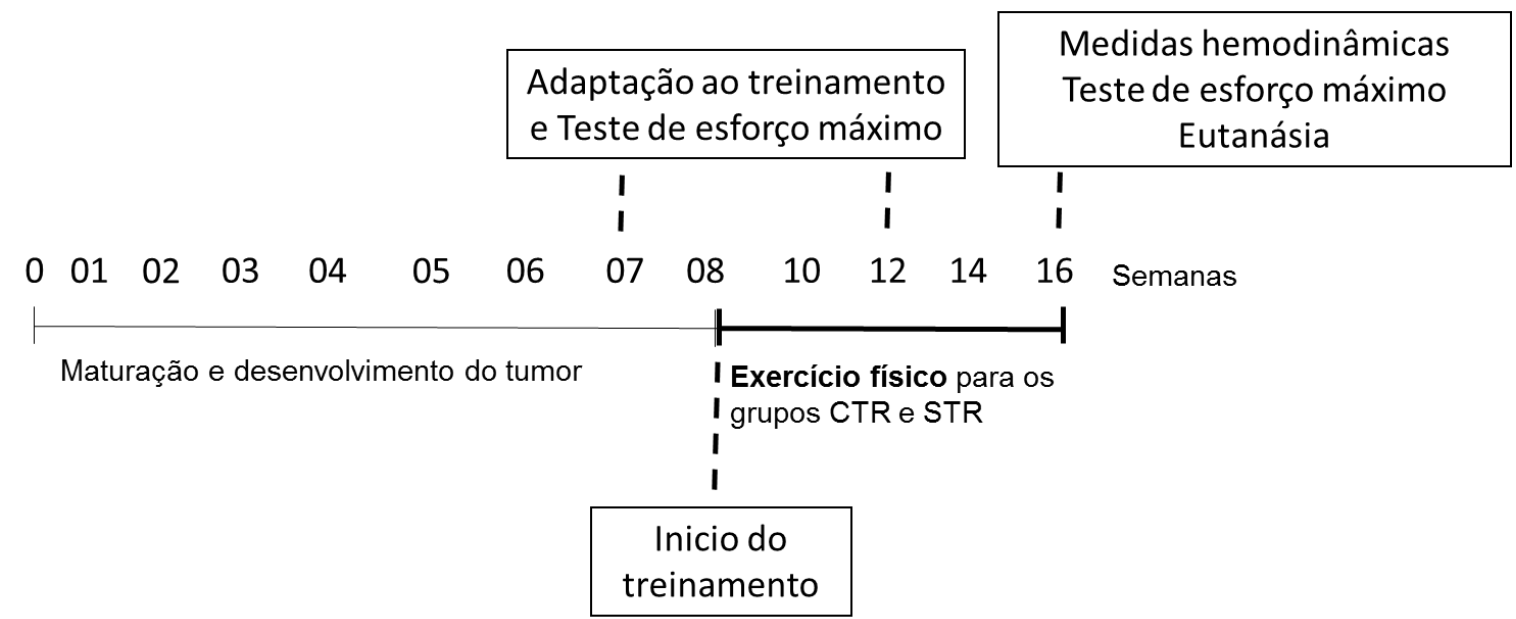

Figura 2. Desenho experimental do estudo 1; modelo MMTV; PyMT. CS= câncer sedentário e CTR= câncer treinado.

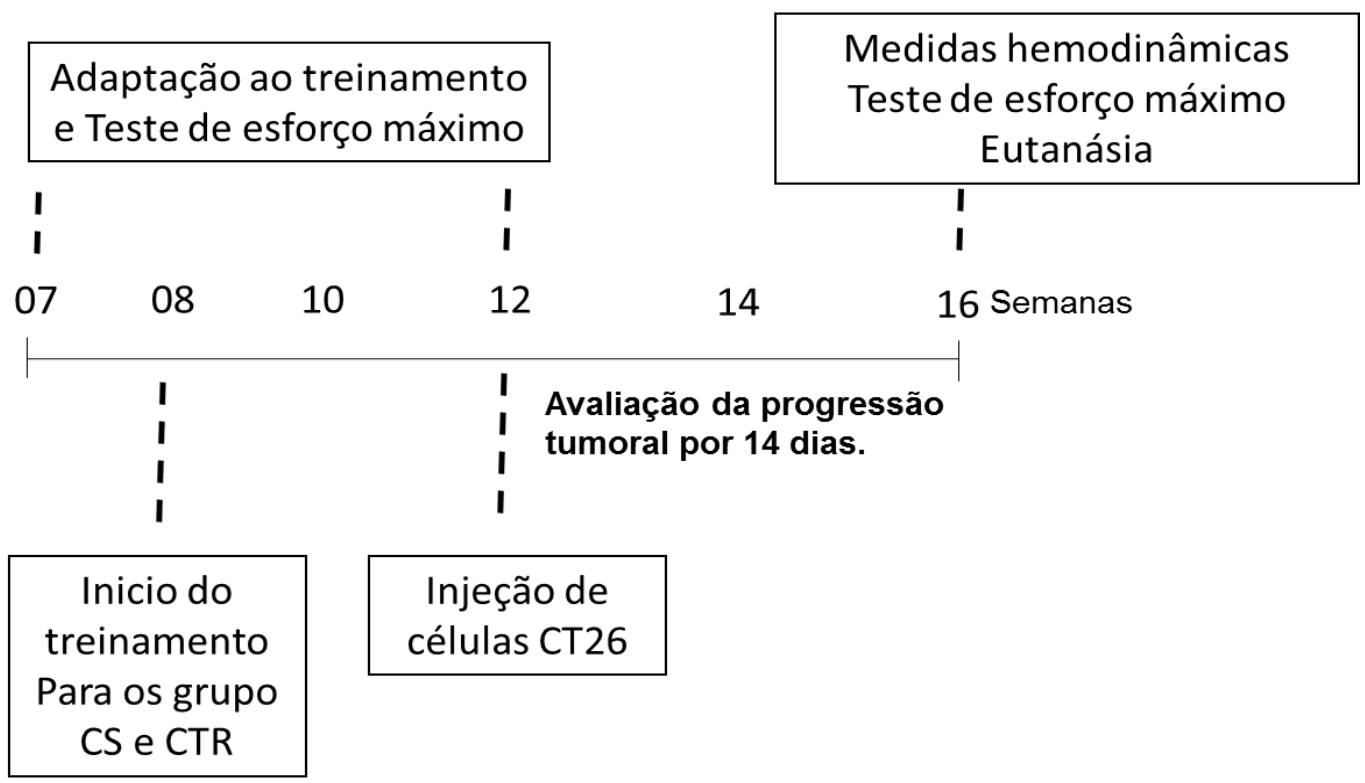


Figura 3. Desenho experimental do estudo 2; Modelo CT26. CS= câncer sedentário e CTR= câncer treinado.

\subsection{Medidas morfológicas e hemodinâmicas}

Logo após o sacrifício dos animais os seguintes órgãos/tecidos foram pesados: coração, fígado, rins, gordura perigonadal, pulmão, tumor e músculos (sóleo, tibial anterior, gastrocnêmicos e plantar). Como houve variação entre a massa dos animais nós dividimos o peso dos tecidos citados pelo comprimento da tíbia, dessa forma temos um fator de correção para assegurar que as diferenças encontradas no peso dos tecidos não estão relacionadas somente com a massa dos animais dos animais. Para medir o comprimento das tíbias e volume tumoral utilizamos um paquímetro. O volume tumoral foi avaliado por paquímetro, as medidas foram feitas duas vezes por semana para os animais MMTV e diariamente para os animais CT26.

No estudo 1 aferimos a frequência cardíaca de repouso realizada por pletismografia de cauda depois do término do protocolo de treinamento (sistema da KENT SCIENTIFIC RTBP1001 para ratos e camundongos, Litchfield, EUA) nos 4 grupos de animais. Os animais foram submetidos à restrição de movimento em uma caixa de acrílico e, para haver vasodilatação, eles foram expostos a aquecimento moderado. Foi posto um manguito de borracha, próximo a cauda, ligado a um esfigmomanômetro, para insuflar e desinflar gradualmente o manguito de 0 a 250/300 mmHg. Na porção mais distal da cauda foi acoplado um transdutor pneumático para detectar os sinais da passagem da onda de pulso de pressão da artéria caudal. A frequência cardíaca foi calculada a partir do intervalo de pulso de pressão arterial detectado pelo transdutor, sem a oclusão da passagem do fluxo sanguíneo na cauda.

Para cada animal foram realizadas 5 medidas, sendo desprezadas a primeira e a última medida e, com os resultados remanescentes, foi realizado 0 cálculo da média aritmética. Os resultados foram expressos em batimentos por minuto (bpm). 


\subsection{Testes funcionais e protocolo de treinamento}

Avaliação da tolerância ao esforço físico máximo: Para realização do protocolo de avaliação do esforço físico máximo, os animais dos 4 grupos foram posicionados individualmente sobre a esteira rolante. A velocidade inicial foi de $3 \mathrm{~m} / \mathrm{min}$ (sem inclinação), que constitui em um protocolo escalonado com incrementos de velocidade de $3 \mathrm{~m} / \mathrm{min}$ a cada $3 \mathrm{~min}$, até ser atingida a velocidade máxima suportada por cada animal (Ferreira et al., 2007). O critério para a determinação da exaustão do animal e interrupção do teste foi 0 momento em que o camundongo não era mais capaz de correr mediante 0 incremento de velocidade da esteira. Esta avaliação foi feita pré, durante e pós o período de treinamento, para comparar a resposta de desempenho do animal entre os grupos.

Deambulação: No estudo 1 para a análise da função muscular esquelética foi utilizado o teste comportamental de deambulação que estima a força contrátil e a coordenação motora. Para isso, as patas traseiras dos animais foram colocadas em contato com tinta preta não tóxica e em seguida eles foram posicionados dentro de uma caixa retangular de madeira (sem teto e forrada com papel branco) para caminharem. Posteriormente, o comprimento das passadas foi medido.

Grip Strength Meter: No estudo 2 para avaliarmos a função muscular utilizamos o teste de preensão, onde avaliamos o efeito do exercício físico sobre a força de tração dos membros anteriores e posteriores, $O$ equipamento utilizado para essa medida é proveniente da empresa New Primer, São Paulo, Brasil. Os animais foram posicionados no equipamento, suspensos pela cauda, e estimulados a tracionar o gradil acoplado a um dinamômetro. Realizamos três medidas para cada animal e analisamos a maior delas. Os resultados foram expressos em quilogramas $(\mathrm{kg})$ os testes foram realizados após o protocolo de treinamento.

\subsection{Histologia}

\section{Imunofluorescência para miosina de cadeia pesada tipo I (MHCl):}

Após vinte e quatro horas da última sessão de treinamento os animais foram sacrificados e extraído cuidadosamente o músculo sóleo e tibial anterior 
e fixado em uma massa de montagem à base de tissue tek (com a finalidade de manter o tecido na posição correta para o pré-congelamento) pela região tendinosa. Posteriormente à fixação do tecido na massa de montagem à base de tissue tek, os músculos foram mergulhados em isopentano (um crioprotetor que evita artefatos nas amostras) durante 10 segundos e, posteriormente, foram mergulhados em nitrogênio líquido para o congelamento, com conservação em aproximadamente $-196^{\circ} \mathrm{C}$, onde foram mantidos até a realização dos cortes. Os cortes foram realizados em Criostato Micron Hm505E (Zeiss, Walldorf, Germany) com espessura de $8 \mu \mathrm{m}$. Após obter os cortes transversais, que possuíam espessura de $10 \mu \mathrm{m}$, foi realizada a técnica de imunofluorescência para $\mathrm{MHCl}$ e Laminina.

Esta técnica foi escolhida devido a sua grande especificidade na identificação desse tipo de fibra (Tipo I). Nesta técnica, as secções são previamente fixadas com formalina (Sigma-Aldrich, HT501128, Brasil) 10\% por 10 minutos em temperatura ambiente, permeabilizadas em $0,2 \%$ de Triton $X$ 100 (Biorad, 01-0407, EUA) e 1\% albumina sérica bovina (BSA; Amresco, E588, EUA) diluídos em PBS (Phosphate Buffer Saline; Tampão Fosfato Salino; Sigma-Aldrich, P4417, Brasil) por 10 minutos. O bloqueio é feito em $10 \%$ goat serum (Sigma-Aldrich, G9023, Brasil) em PBS por 45 minutos. As lâminas são incubadas com solução contendo os anticorpos primários contra 1) $\mathrm{MHCl}$ (diluição 1:6000) para a diferenciação da fibra muscular do tipo I; e 2) Laminina (diluição 1:100) para a marcação das demais fibra musculares, negativas para tipo I, ou seja, fibras do tipo II; com 1,5\% de goat serum em PBS por 1 h e 30 minutos em temperatura ambiente. Após a lavagem com $0,2 \%$ de Triton X-100 em PBS (3 vezes de 10 minutos cada), os cortes são incubados por 40 minutos em sala escura com uma solução PBS contendo $1,5 \%$ de goat serum, os respectivos anticorpos secundários fluorescentes para $\mathrm{MHCl}$ (diluição 1:500; Alexa Fluor 568 goat anti-mouse, Life Technologies, A11004, EUA) e Laminina (diluição 1:500; Alexa Fluor 488 goat anti-rabbit, Life Technologies, A11008, EUA) e Hoechst (diluição 1:1000, para visualização dos núcleos). Após 30 minutos de lavagem em $0,2 \%$ de Triton X-100 em PBS as lâminas são cobertas com lamínulas utilizando-se glicerol tamponado $(60 \%$ Glicerol, 40\% Tris- $\mathrm{HCl} 0,1 \mathrm{M} \mathrm{pH} 9,3)$. 
A captura das imagens foi realizada com aumento de 200x e objetiva de 20x. Analisamos 15 campos de cada lâmina e o registro das imagens foi realizado em computador acoplado a um microscópio fluorescente e conectado a um sistema fotográfico (magnificação de 200x) (Leica Qwin, Leica Microsystems, Alemanha).

A quantificação da área de secção transversa dos diferentes tipos de fibras dos músculos sóleo e tibial anterior foi realizada por meio do programa Image J. Os resultados foram expressos em $\mu \mathrm{m}^{2}$.

\subsection{Real time PCR}

A expressão dos microRNAs foi analisada por reação em cadeia de polimerase em tempo real (real-time PCR). Foram usadas amostras $(15 \mathrm{mg})$ congeladas do músculo esquelético tibial para extração RNA, para isso as amostras foram homogeneizadas em Trizol $(700 \mu \mathrm{l})$, e o RNA foi isolado segundo às instruções do fabricante (Invitrogen Life Technologies, Strathclyde, UK). Além do tecido muscular nós também extraímos RNA do sangue através do kit miRNeasy Serum/Plasma (Qiagen, USA) seguindo as instruções do fabricante.

As amostras foram quantificadas por espectrofotometria em 260nm e verificada à integridade por "agarose gel electrophoresis".

O cDNA para análise de microRNAs foi sintetizado a partir do RNA total utilizando primers específicos para cada microRNA analisado de acordo com o protocolo TaqMan microRNA Assay (Applied Biosystems, CA, USA). Foram utilizados $10 \mathrm{ng}$ de RNA em $1 \mu \mathrm{l}$. Foi preparada uma RT master mix com dNTPs $100 \mathrm{mM}$, multiscribe reverse transcriptase $50 \mathrm{U} / \mathrm{ml}$, tampão $10 x$ para a enzima, inibidores de RNAse $20 \mathrm{U} / \mathrm{ml}$, totalizando $7 \mu \mathrm{l}$. Foram adicionados $3 \mu \mathrm{l}$ de primer e água livre de nuclease para completar o volume de $15 \mu$ de reação. A reação de $\mathrm{PCR}$ foi realizada a $16^{\circ} \mathrm{C}$ por $30 \mathrm{~min}, 42^{\circ} \mathrm{C}$ por $30 \mathrm{~min}, 85^{\circ} \mathrm{C}$ por 5 min e após as amostras foram mantidas a $4^{\circ} \mathrm{C}$.

Para a reação de (RT-PCR) para expressão de microRNAs foram usados $20 \mu \mathrm{l}$ da reação de PCR e adicionados $1,33 \mu \mathrm{l}$ do produto $\mathrm{RT}, 10 \mu \mathrm{l}$ de TaqMan 2X Universal PCR master mix II (No AmpErase UNG), $1 \mu \mathrm{l}$ de primer (TaqMan microRNA Assay 20X) e 7,67 $\mu \mathrm{l}$ de água livre de nucleases. As 
reações foram incubadas a $95^{\circ} \mathrm{C}$ por $10 \mathrm{~min}$, seguidos por 40 ciclos de $95^{\circ} \mathrm{C}$ por 15 segundos e $60^{\circ} \mathrm{C}$ por $1 \mathrm{~min}$. As fluorescências foram lidas em detector ABI PRISM 7500 (Applied Biosystems). Foi utilizado o U6 snRNA como normalizador para análise de cada microRNA muscular testado.

\subsection{Análise expressão proteica}

Foi utilizada a técnica de Eletroforese em Gel de Poliacrilamida (SDSPAGE), que consiste na migração de moléculas com carga, numa solução, decorrente da aplicação de um campo elétrico no aparelho minigel (Mini Protean, BioRad, EUA). As proteínas foram transferidas para uma membrana de nitrocelulose (American Biosciences, NJ, EUA) e incubada em solução contendo albumina e o anticorpo primário que se liga à proteína que se pretende detectar, AKT (ABCAM), foxo1a (ABCAM), pfoxo1a (ABCAM), foxo3a (ABCAM), pfoxo3a(ABCAM), PI3K (Cell signaling), PTEN (Cell signaling), HDAC4 (Cell signaling), PAX3 (ABCAM), PAX7 (ABCAM), mTOR (Cell signaling), formando um complexo anticorpo-proteína. Depois realiza-se a lavagem da membrana para remover 0 anticorpo não ligado. Na sequência as membranas foram expostas ao anticorpo secundário por 2 horas, direcionado a porção espécies-específicas do anticorpo primário. O complexo foi detectado mediante reação de quimiluminescência $(E C L)$ e os blots foram visualizados e quantificados pelo sistema Image $J$, fornecido gratuitamente pela NIH (EUA) via internet. A proteína GAPDH (Gliceraldeído-3-fosfato-desidrogenase) foi utilizada como normalizador.

\subsection{Estatística}

Foi utilizada a análise de variância de duas vias (câncer e treinamento físico como fatores independentes) para comparar os valores dos grupos. Em caso de significância, foi aplicado o teste de Tukey para detectar diferenças entre médias (Graphpad Prism 6 software, EUA). Foi adotado para todos os experimentos $p<0,05$ para expressar significância. Todos os resultados estão apresentados na forma de média \pm erro padrão da média (EPM). Testes de outlier foi realizado através do algoritmo QuickCalcs (encontrado no endereço de internet: http://graphpad.com/quickcalcs/grubbs1/). O cálculo amostral foi obtido através do algoritmo Lasec (encontrado no endereço de internet: :http://www.lasec.cuhk.edu.hk/sample-size-calculation.html), 0 poder da 
amostra adotado foi de $80 \%$ com o $p<0,05$, utilizamos valores de média e desvio padrão de estudos prévios sobre atrofia muscular e câncer (Ruas et al., 2012) para o cálculo amostral e chegamos ao número de 40 animais.

\section{Resultados}

\subsection{Estudo 1}

\subsubsection{Marcadores de treinamento}

Os primeiros resultados apresentados são acerca da eficácia do protocolo de treinamento que os animais foram submetidos. Os resultados da frequência cardíaca refletem a eficácia do protocolo de treinamento. No final do protocolo os animais dos grupos STR e CTR apresentaram significante bradicardia de repouso, quando comparados com os seus respectivos controles SS e CS (figura 4A).

Corroborando com os resultados de frequência cardíaca, os dados obtidos no teste de esforço máximo também apontam para eficácia do treinamento. Os animais dos grupos que realizaram o protocolo de treinamento também apresentavam melhor desempenho em relação a distância máxima percorrida (figura 4B). Entretanto, é importante ressaltar que os dados sugerem que o câncer leva ao prejuízo da capacidade aeróbica, pois os animais do grupo CS apresentaram uma expressiva queda no desempenho. Observa-se que os animais desse grupo na $4^{\text {a }}$ semana do protocolo de treinamento já apresentavam uma tendência de diminuição na distância máxima percorrida e na velocidade máxima alcançada, e, na $8^{\text {a }}$ semana do protocolo estes animais já apresentavam significante queda em todos esses parâmetros. Em contrapartida, o grupo CTR não apresentou queda no desempenho, mas não mostrou crescimento significativo na distância máxima percorrida e nem na velocidade máxima. Dessa forma os resultados indicam que o treinamento aeróbico para os animais com câncer de mama foi eficiente em atenuar a queda da capacidade aeróbica.

A análise da enzima citrato sintase corrobora com os resultados encontrados no teste de esforço máximo; essa enzima é presente no Ciclo do Ácido Cítrico e catalisa a reação que tem como produto o citrato. A avaliação da atividade dessa enzima mostra de forma a eficiência do ciclo do ácido cítrico 
o que está fortemente relacionado com o metabolismo aeróbico. Os animais do grupo STR apresentam um aumento da atividade enzimática quando comparados com os grupos sedentários SS e CS, o mesmo comportamento é observado no grupo CTR que se diferencia dos demais sedentários, muito embora a magnitude do aumento da atividade enzimática do grupo CTR não é proporcional ao grupo STR apesar de haver diferenças estatísticas. O grupo CS apesar de haver diferença estatística em relação ao grupo SS, apresenta os menores resultados frente a todos os grupos (figura 4C).

A

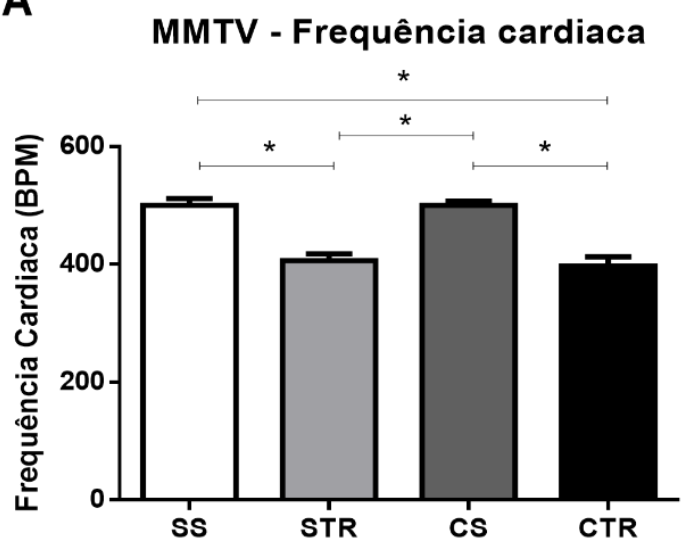

C

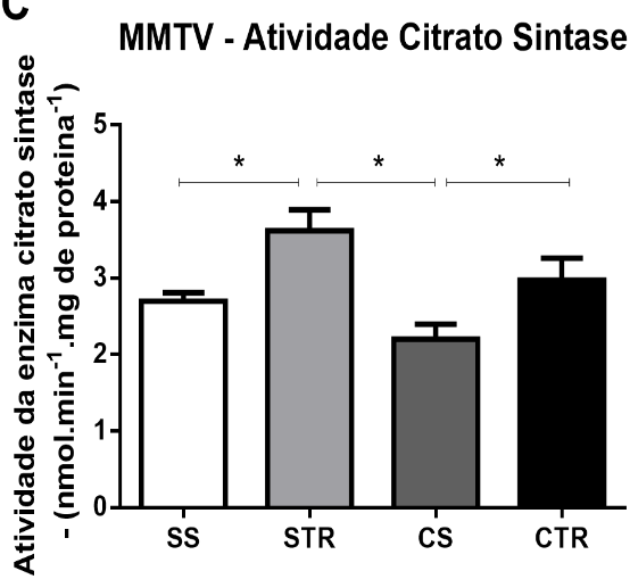

B

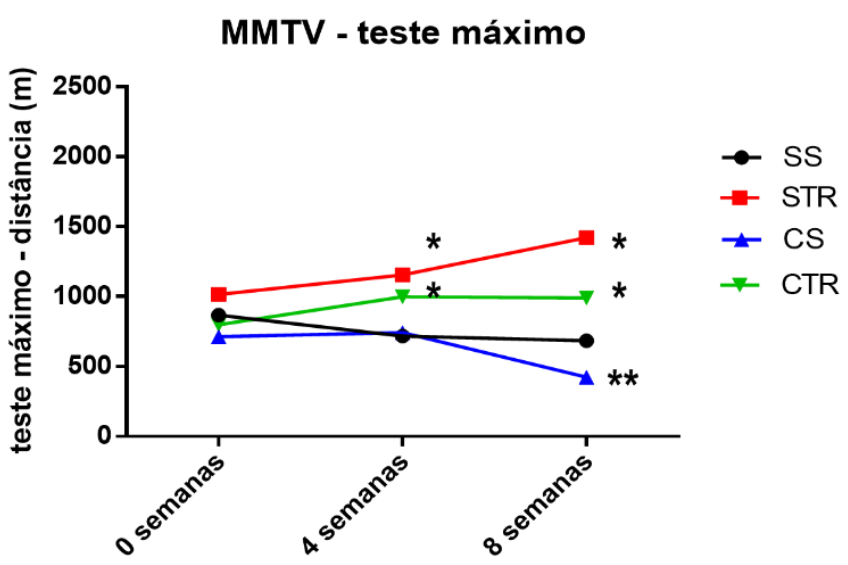

Figura 4. A) Frequência cardíaca de repouso; B) Distância máxima percorrida no teste de esforço máximo. Batimento por minuto (BPM); C) atividade da enzima citrato sintase. Controle Saudável Sedentário (SS), Saudável Treinado (STR); Câncer Sedentário (CS); Câncer Treinado (CTR); * $p<0,05$. 


\subsubsection{Medidas morfológicas}

Uma vez que o treinamento foi eficaz, analisamos algumas estruturas corporais para verificar se o exercício físico e/ou o câncer levam a alterações. Nós avaliamos a massa corporal dos animais e observamos que os animais com câncer, CS e CTR apresentam um aumento de massa corporal, entretanto isso ocorre por conta da presença do tumor, pois quando avaliamos a massa corporal livre do tumor não há diferença entre os grupos (Tabela 1). Avaliando a evolução da massa corporal ao longo do protocolo de treinamento e também não observamos mudanças (figura 5A).

Nós não observamos alteração no peso do tumor em decorrência do treinamento, o volume tumoral também permanece inalterado, analisamos 0 volume tumoral duas vezes por semana (depois do protocolo de treinamento ter iniciado) e no dia da eutanásia, e não observamos diferença entre os grupos ao longo do tempo (figura 5B).

O modelo MMTV-PyMT é tido na literatura como um modelo animal predisposto a metástases, principalmente no pulmão (Ma et al., 2012). Entretanto nós não observamos sinais de metástases no tecido pulmonar e nenhuma outra alteração evidente no pulmão (dados não mostrados). Mesmo com relação ao peso deste tecido não foram observadas diferença significativa entre os grupos experimentais (Tabela 1).

No nosso trabalho nós não administramos nenhuma restrição de alimentação, sendo que os animais recebiam comida ad libidum; ao avaliarmos a gordura perigonadal dos animais, observamos que o grupo CS apresenta um aumento significativo desse tecido em relação a todos os outros grupos (figura 5C). Esse resultado sugere que o câncer pode estar gerando alguma alteração metabólica e que o exercício físico previne essa alteração, uma vez que o grupo CTR tem o mesmo comportamento dos grupos saudáveis.

\section{Tabela 1:}




\begin{tabular}{ccccc} 
& SS & STR & CS & CTR \\
\hline peso do VE $(\mathrm{g} / \mathrm{mm})$ & 0,004 & 0,004 & 0,005 & 0,004 \\
& $\pm 0,0004$ & $\pm 0,0002$ & $\pm 0,0009$ & $\pm 0,0002$ \\
\hline peso do Pulmão $(\mathrm{g} / \mathrm{mm})$ & 0,010 & 0,008 & 0,011 & 0,008 \\
& $\pm 0,004$ & $\pm 0,001$ & $\pm 0,009$ & $\pm 0,001$ \\
\hline peso do tumor $(\mathrm{g} / \mathrm{mm})$ & - & - & 0,020 & 0,018 \\
& - & - & $\pm 0,01$ & $\pm 0,017$ \\
\hline peso livre do tumor $(\mathrm{g} / \mathrm{mm})$ & - & - & 20,0 & 22,2 \\
& - & - & $\pm 1,6$ & $\pm 0,8$ \\
\hline
\end{tabular}

Tabela 1: Peso dos tecidos dividido pelo comprimento da tíbia mostrados em grama/milimetro $(\mathrm{g} / \mathrm{mm})$. Controle Saudável Sedentário (SS), Saudável Treinado (STR); Câncer Sedentário (CS); Câncer Treinado (CTR). Ventrículo esquerdo (VE).
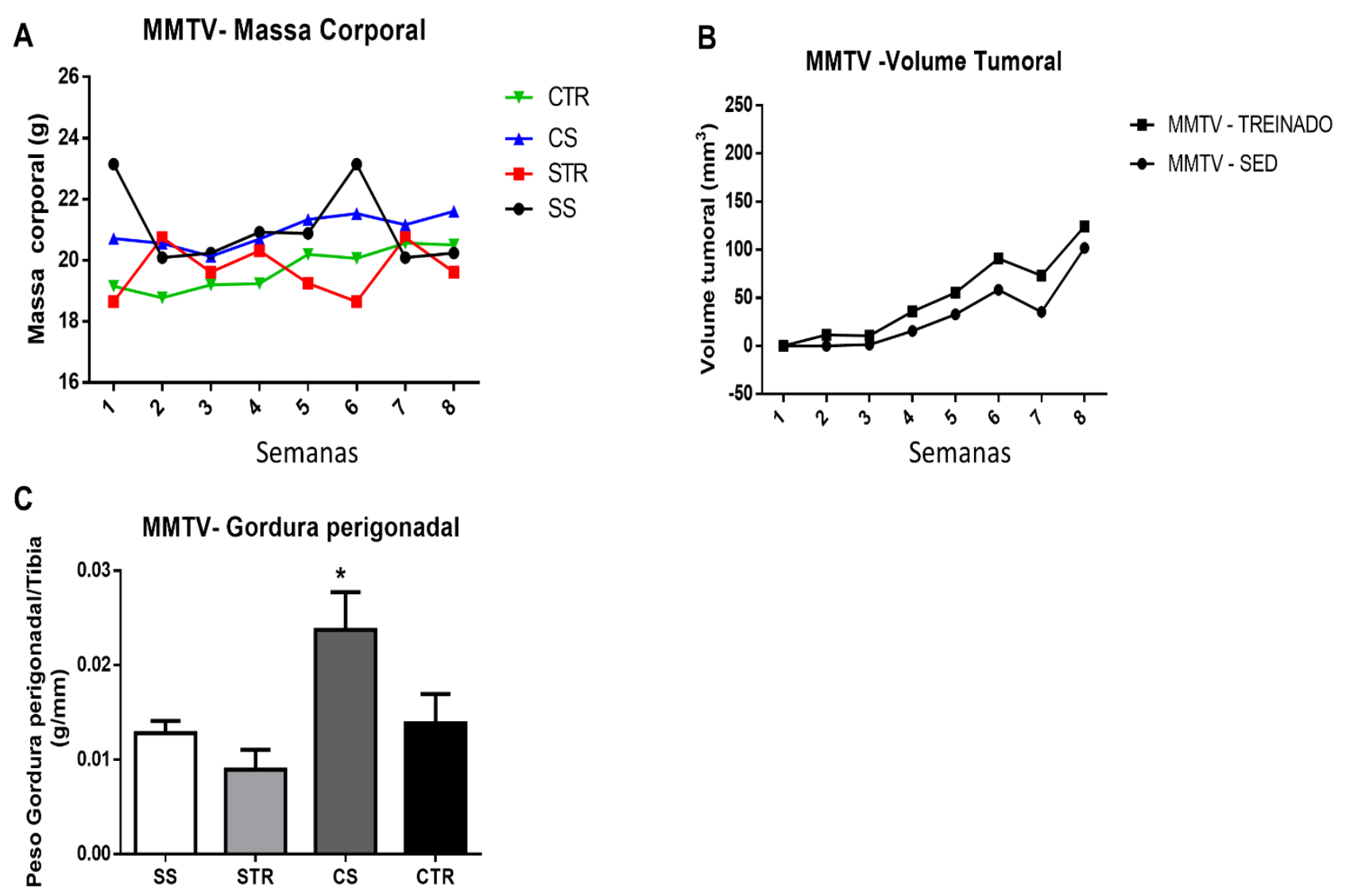

Figura 5: A) Evolução da massa corporal ao longo do tempo; B) Volume tumoral ao longo do tempo; C) Peso da gordura perigonadal corrigido pelo comprimento da tíbia. Controle Saudável Sedentário (SS), Saudável Treinado (STR); Câncer Sedentário (CS); Câncer Treinado (CTR). " $\mathrm{p}<0,05$ CS vs SS, STR e CTR (significância apenas para gordura perigonadal). 


\subsubsection{Caracterização do músculo esquelético}

A caquexia é um processo patológico que leva a perda de massa muscular esquelética e outros tecido e que está fortemente associada a diversos tipos de cânceres (Groarke et al., 2013; Tisdale, 2009), entretanto no câncer de mama a caquexia não é um processo evidente, apesar de existirem indícios de que a musculatura esquelética pode ser afetada no câncer de mama (Chen et al., 2014). Nós pesamos então os músculos sóleo, plantar, gastrocnêmio e tibial anterior (figura 6A) e não encontramos diferenças significativas no peso desses tecidos em decorrência do câncer e nem do treinamento físico. Portanto, esses resultados estão de acordo com literatura.

Os testes funcionais para o músculo esquelético in vivo são importantes indicadores da eficiência na realização de força, coordenação, sustentação e outras capacidades fundamentais deste tecido. Nos nossos resultados nós não encontramos diferenças entre os grupos no teste de deambulação (figura $6 C$ ). Esses dados indicam que possivelmente o músculo esquelético não apresenta prejuízo de função.

Mesmo não encontrando as alterações descritas acima analisamos a área de secção transversa do músculo esquelético, e observamos que não há alterações no trofismo muscular do sóleo e do tibial anterior em nenhum dos grupos (Figura 6B). Salientamos anteriormente que em alguns tipos de câncer a diminuição do tipo de fibra é um fenômeno esperado, entretanto no modelo MMTV-PyMT não há estudos que mostrem o perfil do músculo esquelético destes animais. Dessa forma, os resultados que encontramos são novos, mas são esperados, pois não há evidências de prejuízos na função muscular nesse modelo e em nenhum outro de câncer de mama. Os resultados da imunohistoquímica mostram que também que não há mudanças do tipo de fibra em nenhum dos grupos (resultados não mostrados). 

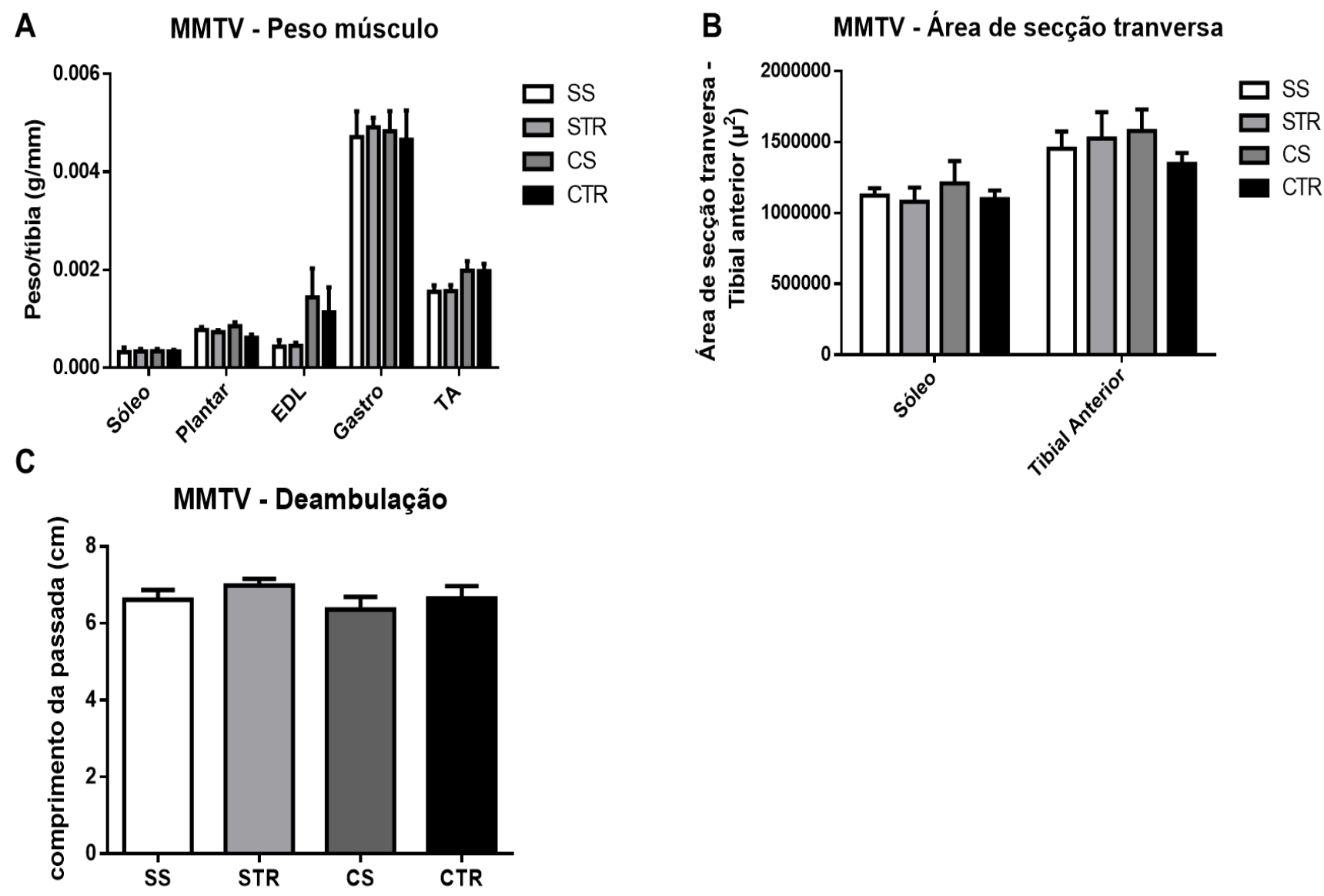

Figura 6: A) Peso dos músculos corrigido pelo comprimento da tíbia B) Área de secção transversa do músculo sóleo e tibial anterior C) Comprimento da passada obtido no teste de deambulação. Controle Saudável Sedentário (SS), Saudável Treinado (STR); Câncer Sedentário (CS); Câncer Treinado (CTR).

\subsubsection{MicroRNAs}

Avaliamos a expressão dos microRNAs 1, 206, 486, 133a e 133b no músculo tibial anterior. Os nossos resultados mostram que os microRNAs 1, 133a e 133b nesse tecido não apresentam diferença de expressão em decorrência do câncer, tão pouco em relação ao treinamento físico, muito embora esses resultados sejam de difícil análise pois há uma grande variação entre os resultados (Figura 7). 
A

MMTV - miR-133a Tibial anterior

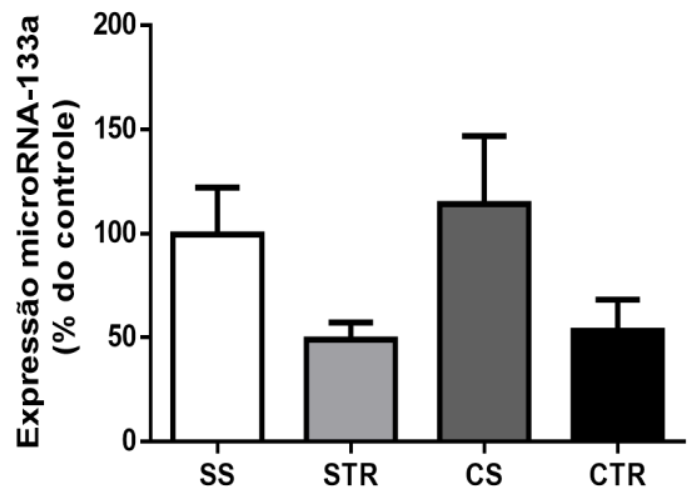

B

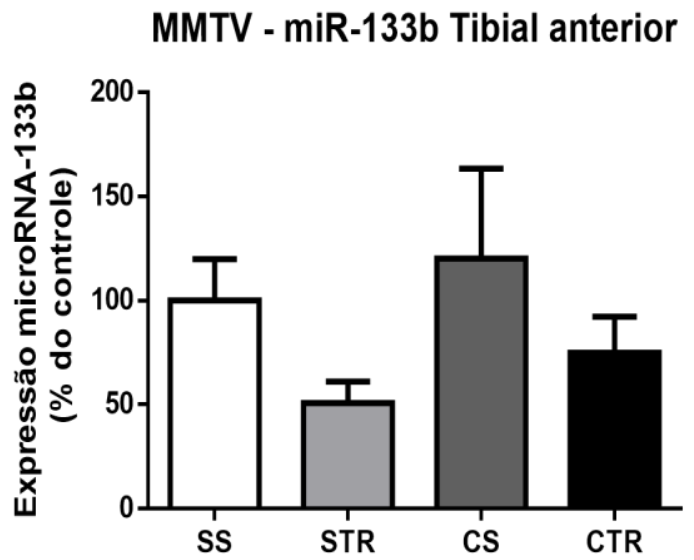

C

MMTV - miR-1 Tibial anterior

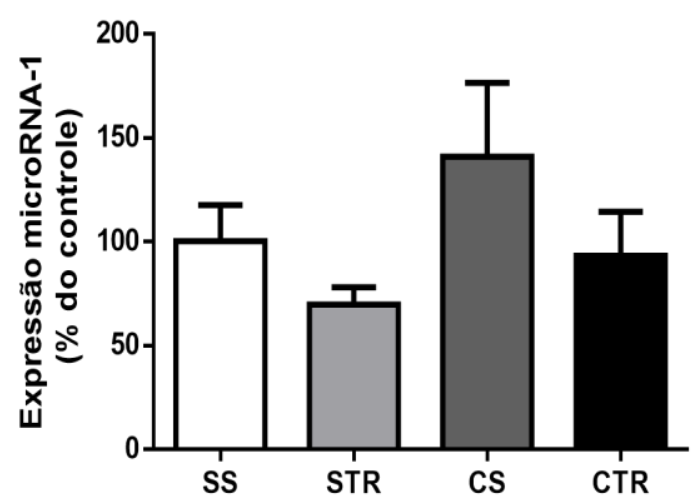

Figura 7: A) Expressão do microRNA-133a no músculo tibial anterior B) Expressão do microRNA-133b no músculo tibial anterior C) Expressão do microRNA-1 no músculo tibial anterior. Controle Saudável Sedentário (SS), Saudável Treinado (STR); Câncer Sedentário (CS); Câncer Treinado (CTR).

Observamos que o padrão de expressão dos microRNAs-206 e -486 apontavam uma alteração que se espera do músculo com prejuízos na síntese proteica, apesar dos resultados sobre o trofismo e a função muscular não acompanharem a expressão diferenciada desses microRNAs (Figura 8A e 8B). Nossos resultados mostram um aumento da expressão do microRNA-206 nos animais do grupo CS, entretanto os animais do grupo CTR não apresentam o aumento da expressão desse microRNA; observamos a diminuição do microRNA-206 em decorrência do treinamento nos animais CTR e STR quando comparados com os animas SS. 
Os resultados do microRNA-486 mostram que os animais CS e CTR apresentam diminuição da expressão quando comparados com SS; o exercício físico nos grupos com câncer não influenciou a expressão desse microRNAs pois não há diferença entre os grupos CS e CTR. Curiosamente, ocorre uma diminuição da expressão do microRNA-486 no grupo STR.

A

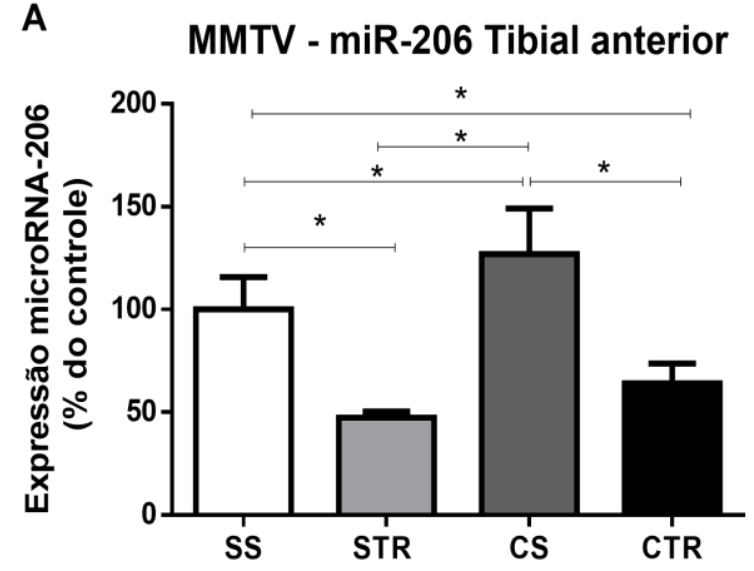

B $\quad$ MMTV - miR-486 Tibial anterior

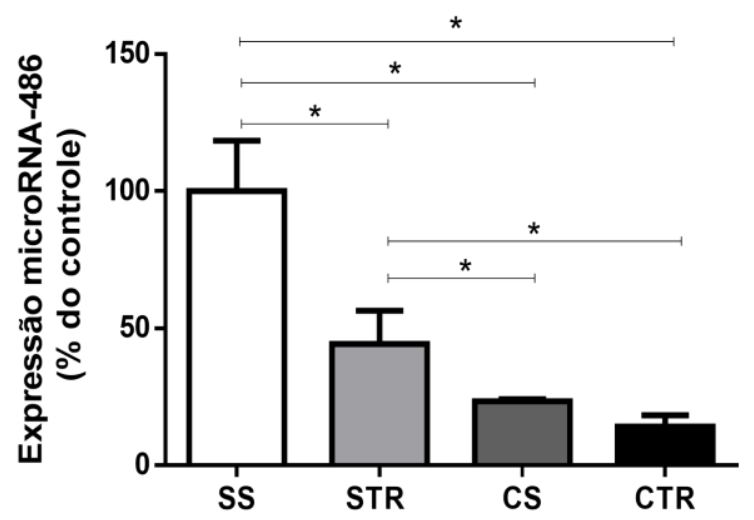

Figura 8: A) Expressão do microRNA-206 no músculo tibial anterior B) Expressão do microRNA-486 no músculo tibial anterior. Controle Saudável Sedentário (SS), Saudável Treinado (STR); Câncer Sedentário (CS); Câncer Treinado (CTR). * $p<0,05$.

Nosso próximo passo foi analisar a expressão dos microRNAs-206 e 486 na circulação para verificarmos se há alterações; analisamos também a expressão na circulação do microRNA-133a apesar de não haver alterações no músculo esquelético.

Os resultados sobre a expressão do microRNA-133a na circulação acompanham os resultados encontrados no músculo esquelético; não havendo diferença entre os grupos e de difícil análise em decorrência de uma grande variabilidade dos resultados (Figura 9a).

Os resultados sugerem que o microRNA-206 tem uma expressão aumentada na circulação dos animais do grupo CS, o grupo CTR também apresenta a expressão aumentada quando comparado com o controle, mas a magnitude do aumento da expressão do grupo CS comparado com o grupo CTR é mais expressiva e estatisticamente os grupos são diferentes entre si. Os 
animais do grupo STR apresentam também um ligeiro aumento da expressão do microRNA-206 na circulação (Figura 9b).

A expressão na circulação do microRNA-486 se apresenta diminuída na circulação do grupo CS e CTR, estes grupos não são diferentes entre si (figura 9c).

A

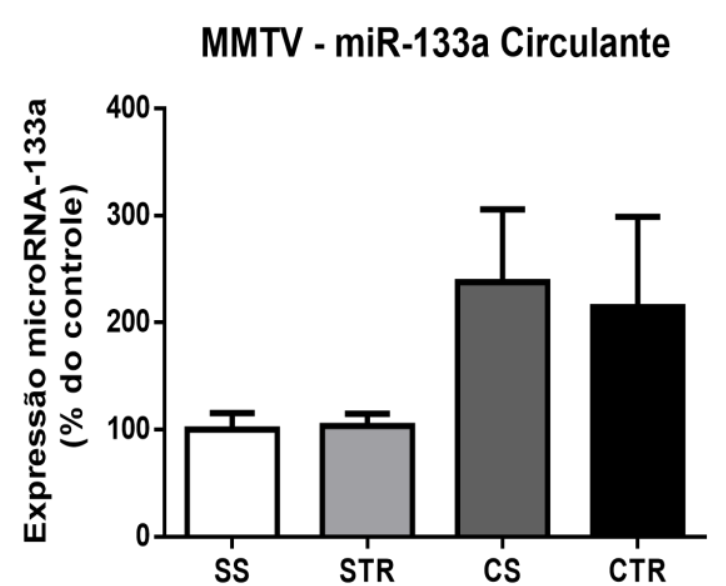

C

MMTV - miR-486 Circulante
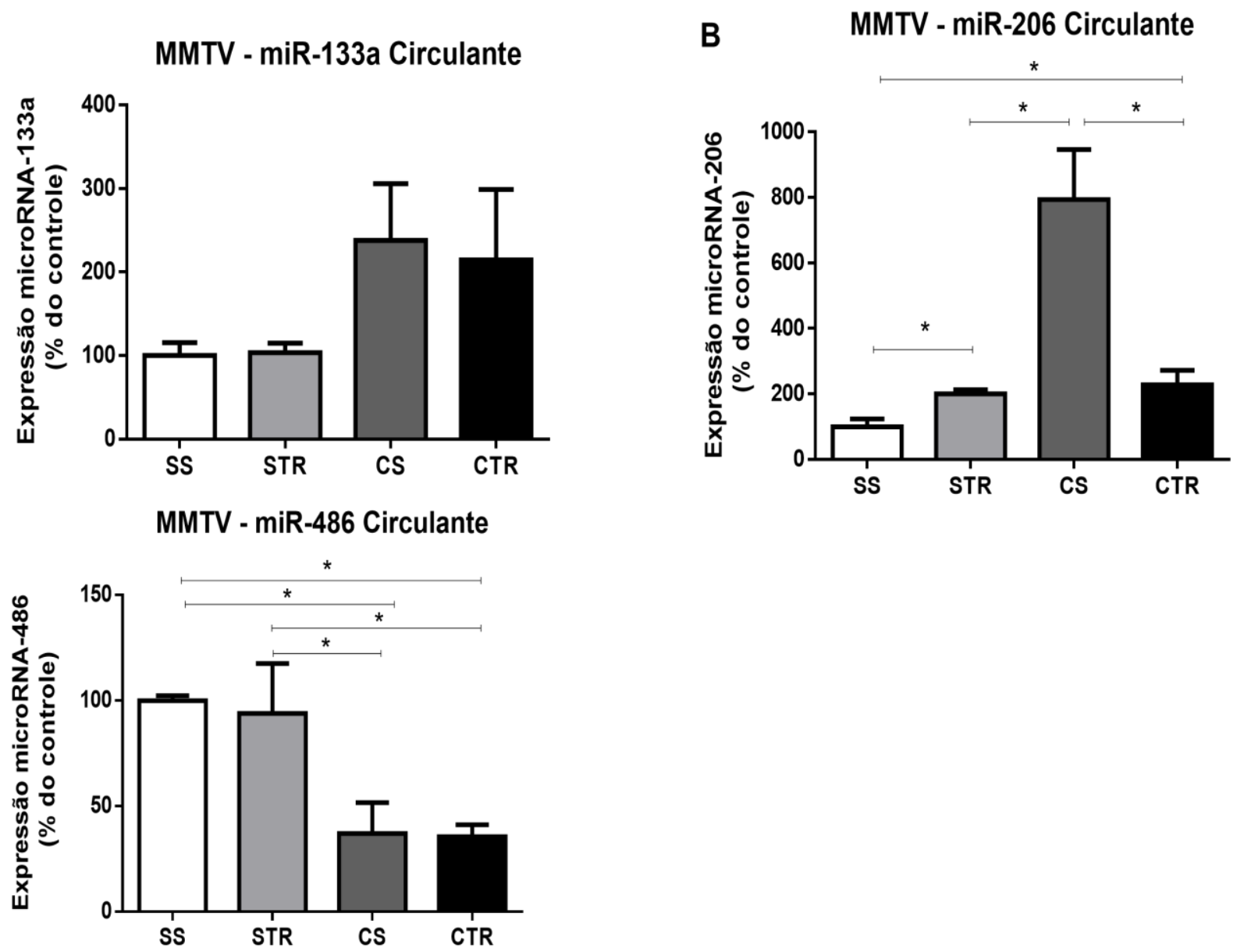

Figura 9: A) Expressão do microRNAs 133a no soro B) Expressão do microRNAs 206 no soro C) Expressão do microRNAs 486 no soro. Controle Saudável Sedentário (SS), Saudável Treinado (STR); Câncer Sedentário (CS); Câncer Treinado (CTR). * $p<0,05$.

Também analisamos a expressão dos myomirRs no tumor. Avaliamos a expressão dos microRNAs-133a, -133b e -206. Os resultados mostram que há a presença desses microRNAs no tumor, algo que é incomum uma vez que esses microRNAs são enriquecidos no músculo esquelético e apresentam baixa ou nenhuma expressão em outros tecidos; o exercício físico influencia pouco na expressão desses microRNAs no tumor, sendo diferentemente 
expresso somente o microRNA-206 (Figura 10a). Comparamos também a expressão desses microRNAs no tumor com a expressão no músculo esquelético dos animais saudáveis e observamos que a expressão desses microRNAs no tumor é muito baixa quando comparado com o músculo (figura 10b). Novos experimentos devem ser conduzidos para entender se essa baixa expressão tem algum efeito biológico.

A

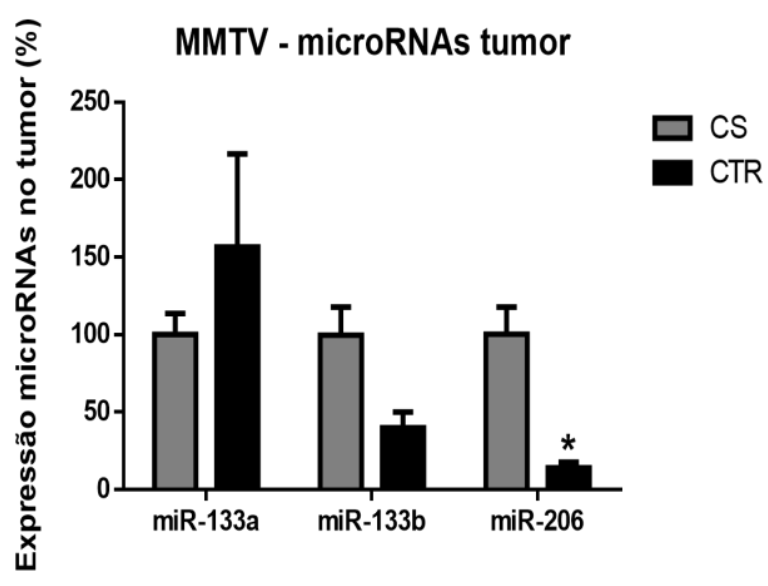

B

MMTV - expressão microRNAs do tumor comparado com músculo esquelético

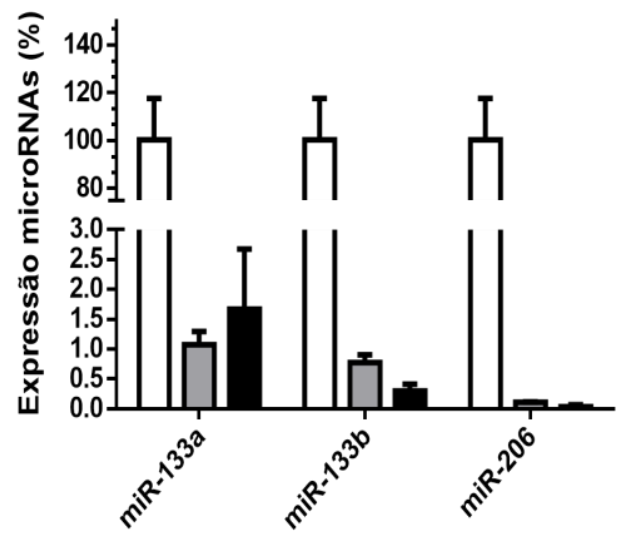

Figura 10: A) Expressão dos microRNAs-133a, -133b e -206 no tumor B) Expressão dos microRNAs-133a, -133b e -206 no tumor comparado com músculo esquelético. Músculo esquelético (ME) e controle Saudável Sedentário (SS), Câncer Sedentário (CS); Câncer Treinado (CTR). * $p<0,05$ vs CS.

\subsubsection{Expressão proteica}

Avaliamos a expressão de proteínas de vias de síntese, degradação e proliferação celular. Analisamos a expressão da proteína PI3K, a mesma se encontra diminuída nos grupos CS e CTR (figura 11B), essa proteína está relacionada com as vias de síntese proteica e por sua vez ativa a proteína AKT iniciando uma cascata de reações que leva ao aumento da atividade de fatores de transcrição e consequentemente a maior tradução proteica além de estar relacionada com maior proliferação, angiogênese e controle metabólico. A proteína AKT está diminuída nos grupos CS e CTR quando comparado com os grupos controles saudáveis(figura 11A). 
O resultado da expressão de AKT nos grupos CS e CTR indicam prejuízos na vias de síntese, mas quando analisamos a expressão da proteína mTOR observamos que não há diferença entre os grupos (Figura 11C), esta proteína é ativada por AKT e por conseguinte ativa fatores de transcrição e aumenta a síntese proteica.

A proteína PTEN regula vias de degradação proteica e é um dos alvos do microRNA-486. Os resultados mostram que não houve diferença na expressão dessa proteína entre os grupos estudados, ao contrário do que se presumiria quando se leva em conta a expressão do microRNA (figura 11D).

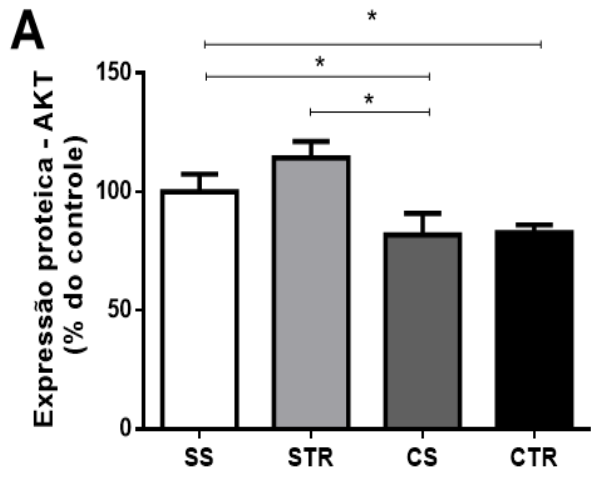

C

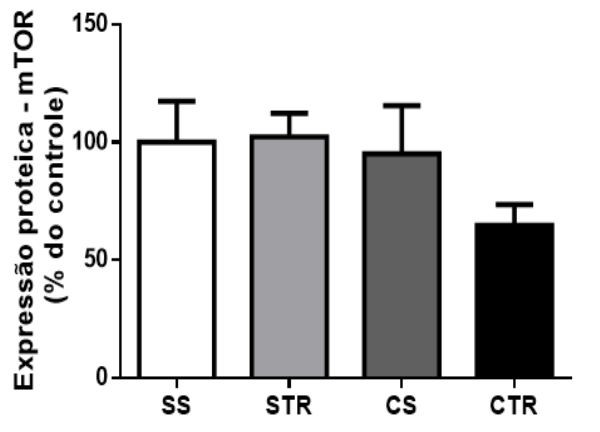

B

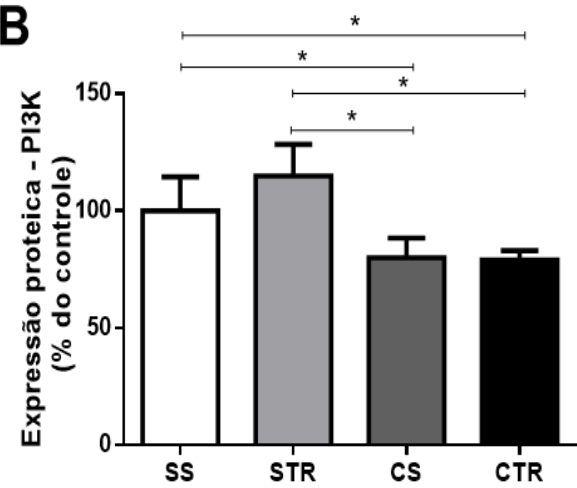

D

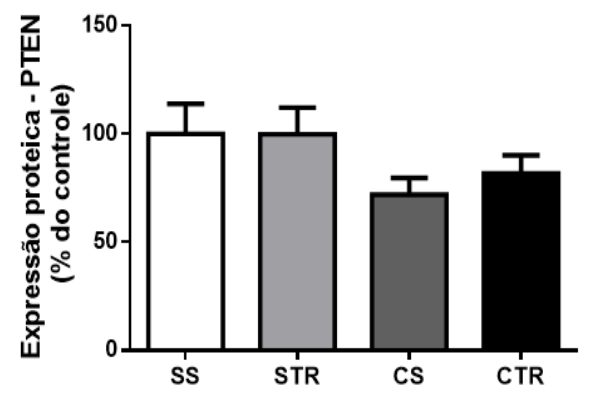

E

$$
\text { SS STR CS CTR }
$$

AKT

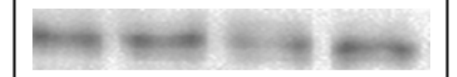

$60 \mathrm{kDa}$

PI3K

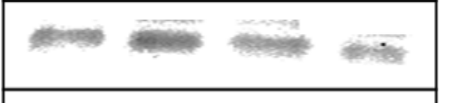

$110 \mathrm{kDa}$

mTOR

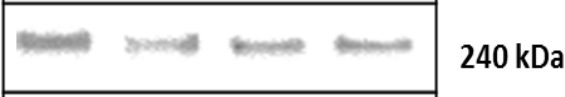

PTEN

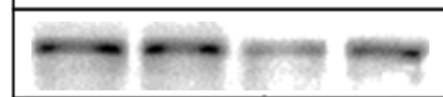

$57 \mathrm{kDa}$

GAPDH

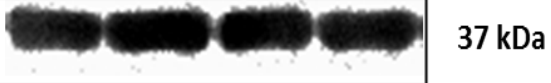


Figura 11: A) Expressão da proteína $A K T$ B) Expressão da proteína $P(3 K$ C) expressão da proteína mTOR D) Expressão da proteína PTEN E) imagem representativa das bandas de proteínas. Controle Saudável Sedentário (SS), Saudável Treinado (STR); Câncer Sedentário (CS); Câncer Treinado (CTR). * $p<0,05$.

As proteínas FOXO1a e FOXO3a e também as suas formas fosforiladas pFOXO1a e pFOXO3a, respectivamente, não apresentam diferença entre os grupos (Figuras 12A-D). Essas proteínas estão relacionadas com diversos processos biológicos, as mesmas são fatores de transcrição e estão relacionadas com a degradação proteica, morte celular e controle metabólico. As mesmas são inibidas pela atividade de AKT, entretanto apesar de observarmos que AKT está diminuída nos grupos CS e CTR esse efeito não afeta a expressão da família de FOXO.

A

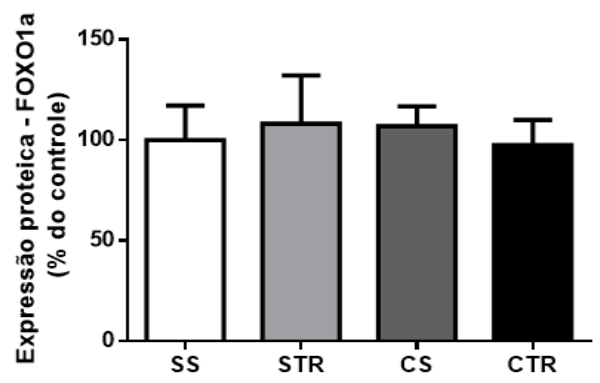

C

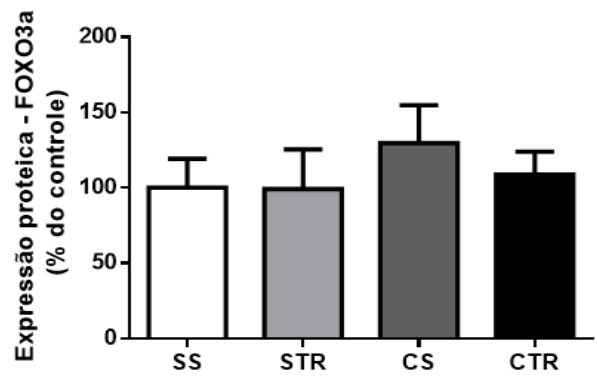

B

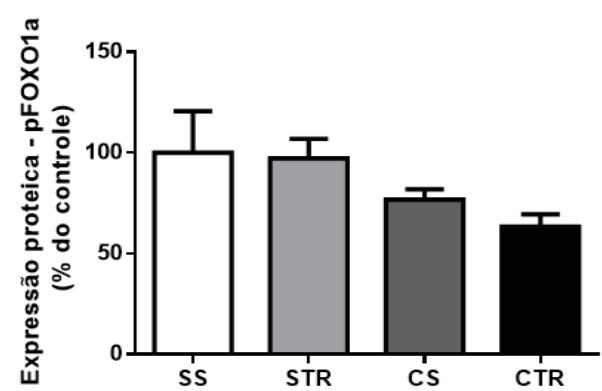

D

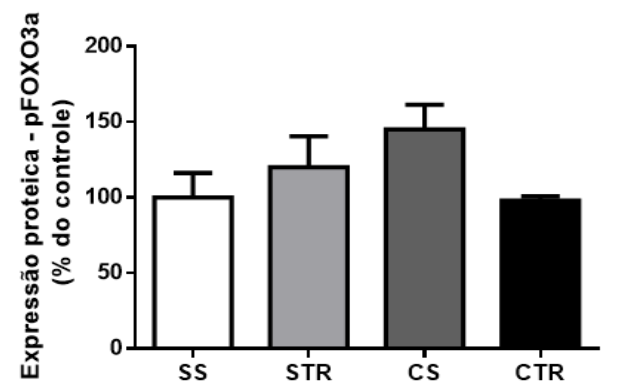

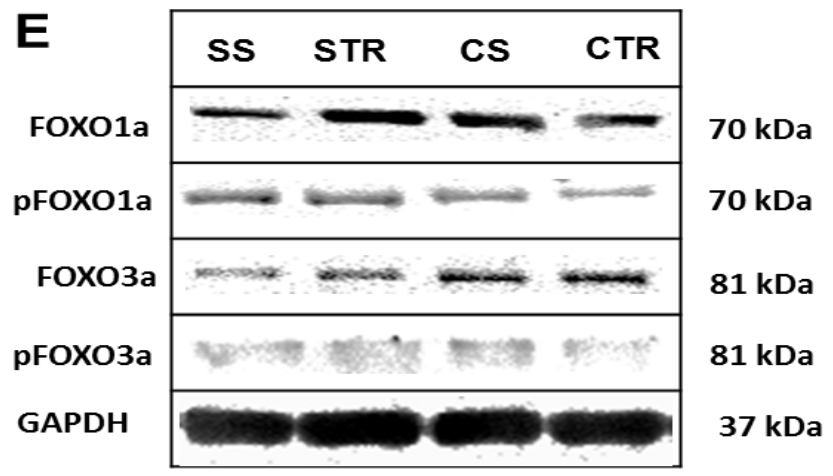


Figura 12: A) Expressão da proteína FOXO1a B) Expressão da proteína pFOXO1a C) expressão da proteína FOXO3a D) Expressão da proteína pFOXO3a E) imagem representativa das bandas de proteínas. Controle Saudável Sedentário (SS), Saudável Treinado (STR); Câncer Sedentário (CS); Câncer Treinado (CTR).

A proteína PAX7 e PAX3 também não se mostram diferentes entre os grupos (Figura 13B e 13C respectivamente), essas proteínas estão associadas com a proliferação das células musculares. A expressão dessas proteínas aumenta em decorrência de injurias no músculo esquelético, mas a sua expressão é logo diminuída quando a proliferação é sessada e se começa o processo de diferenciação muscular. Essa proteína é alvo do microRNA-206. Outro alvo do microRNA-206 é a proteína HDAC4, esta é uma histona deacetilase ela inibe a transcrição de mRNAs e consequentemente diminui a síntese proteica. A expressão de HDAC4 não apresenta diferença entre os grupos (Figura 13A).

A

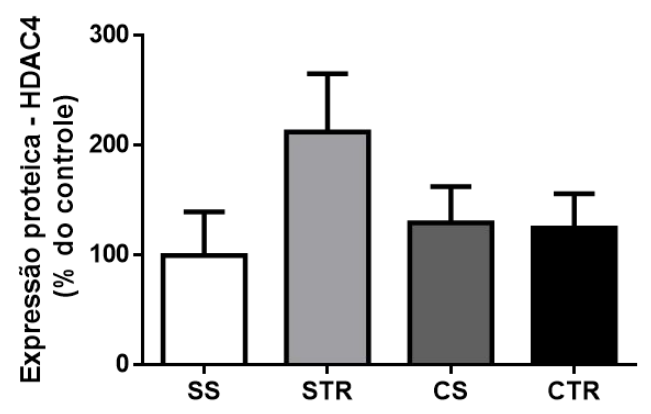

C

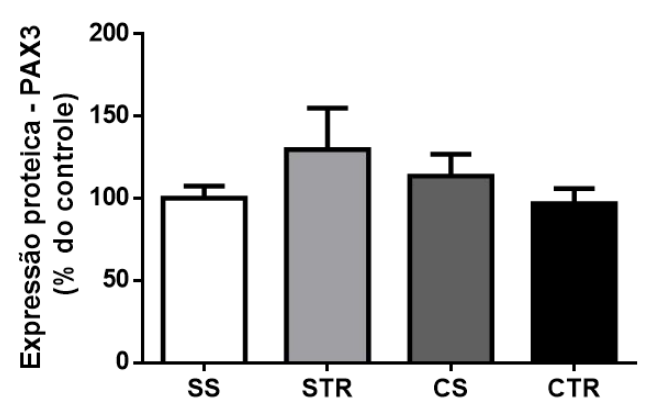

B

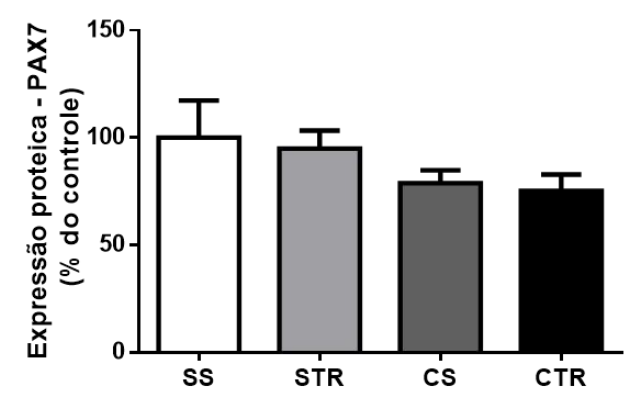

D

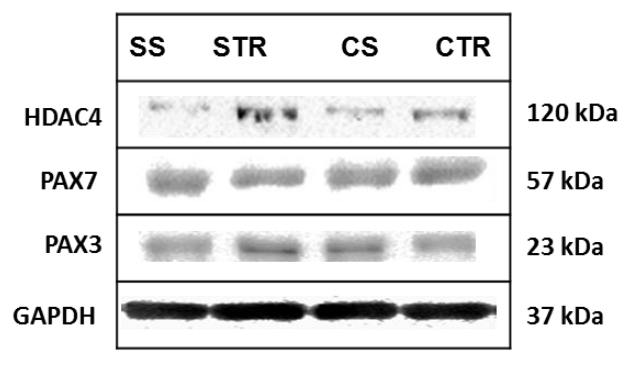

Figura 13: A) Expressão da proteína HDAC4 B) Expressão da proteína PAX7 C) expressão da proteína PAX3 D) imagem representativa das bandas de 
proteínas. Controle Saudável Sedentário (SS), Saudável Treinado (STR); Câncer Sedentário (CS); Câncer Treinado (CTR).

Os resultados no modelo MMTV mostram que não existem alterações na massa e função do músculo esquelético, as análises da expressão proteica confirmam os resultados, muito embora algumas proteínas relacionadas com a síntese proteica apresentam menor expressão nos grupos CS e CTR, tais como PI3K e AKT. Entretanto, as proteínas das vias de degradação e proliferação não apresentam diferença entre os grupos; sugerindo que 0 musculo esquelético se encontra preservado.

Por outro lado, nossos resultados mostram que os microRNAs-206 e 486 apresentam expressão alterada no músculo esquelético e no soro em decorrência do câncer. Dessa forma, para confirmar se o câncer influencia a expressão dos myomiRs e se este fenômeno pode influenciar a função ou a massa do músculo esquelético passamos a avaliar a expressão desses dois microRNAs em um modelo robusto de caquexia do câncer.

Dessa forma a partir de agora mostraremos os resultados do Estudo 2 com o modelo CT26.

\subsection{Estudo 2}

\subsubsection{Marcadores de treinamento}

Os resultados do teste de esforço máximo nos animais CT26, semelhante aos animais MMTV, mostram que o câncer diminui a capacidade aeróbica, entretanto no modelo CT26 o treinamento não foi capaz de prevenir a queda da capacidade de sustentar o esforço nos animais com câncer e treinados. O CS apresenta queda no desempenho depois de 7 dias com 0 tumor; 12 dias (2 dias antes do sacrifício) com o tumor a capacidade de sustentar o esforço é ainda mais prejudicada. Os animais do grupo CTR apresentam melhora no desempenho até 7 dias depois da injeção das células cancerosas, entretanto a capacidade de sustentar o esforço cai de modo acentuado e no $12^{\circ}$ dia a capacidade de sustentar o esforço é baixa e semelhante ao grupo CS. Os resultados do grupo SS e STR estão de acordo com o esperado, baseado nos dados da literatura, o primeiro não muda a 
capacidade de resistir ao esforço ao longo do protocolo, e o segundo resiste mais à exaustão (figura 14A).

A atividade de enzima citrato sintase mostra que os animais dos grupos CS e CTR apresentam resultados semelhantes e, também, mais baixos que os animais sem tumor apesar de não haver diferença significativa em relação o grupo SS. Dessa forma os resultados sugerem que nesse modelo há uma perda da capacidade aeróbica que o exercício físico não é capaz de prevenir. Os resultados do grupo STR estão de acordo com o esperado havendo aumento significativo da atividade enzimática em relação ao controle SS (figura 14B)

O conjunto dos dados mostram que o treinamento foi efetivo, mas 0 câncer decresce a capacidade aeróbica.

A

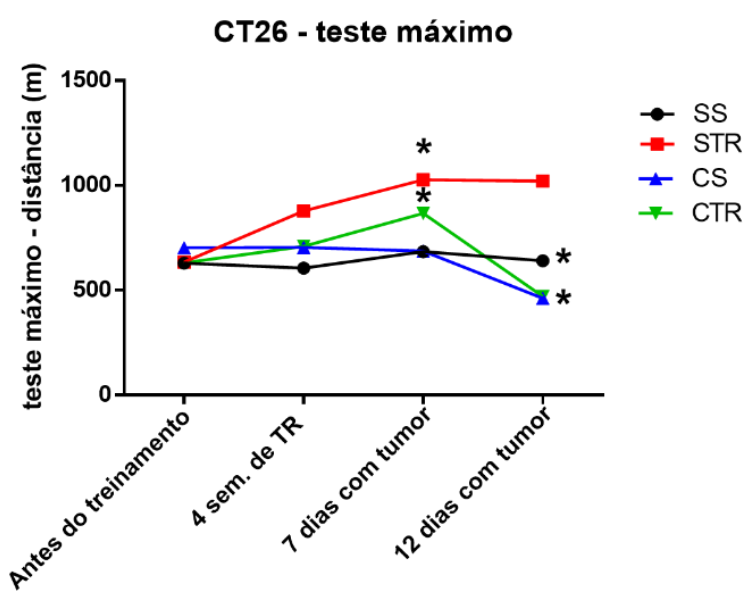

B CT26 - Atividade citrato Sintase

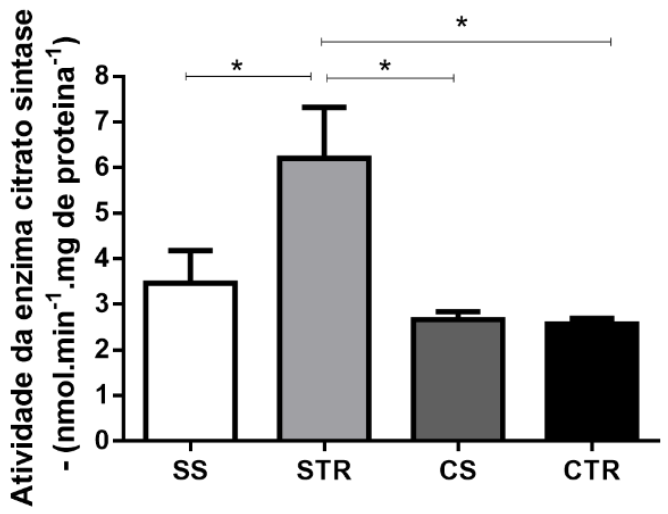

Figura 14: A) Distância máxima percorrida no teste de esforço máximo B) atividade da enzima citrato sintase. Controle Saudável Sedentário (SS), Saudável Treinado (STR); Câncer Sedentário (CS); Câncer Treinado (CTR); * $p<0,05$.

\subsubsection{Medidas morfológicas e funcionais}

O treinamento apesar de não preservar a perda da capacidade aeróbica por decorrência do câncer, nós observamos que o treinamento leva a um e menor volume tumoral ex vivo (figura 15A). O câncer também leva a diminuição da massa corporal, os animais do grupo CS e CTR apresentam diminuição da massa corporal total (figura 15B) livre do tumor (figura 15C). Mostramos 
também que a gordura perigonaldal diminui de modo drástico nos animais do grupo CS e CTR quando comparado com os animais saudáveis SS e STR (figura 15D).

A

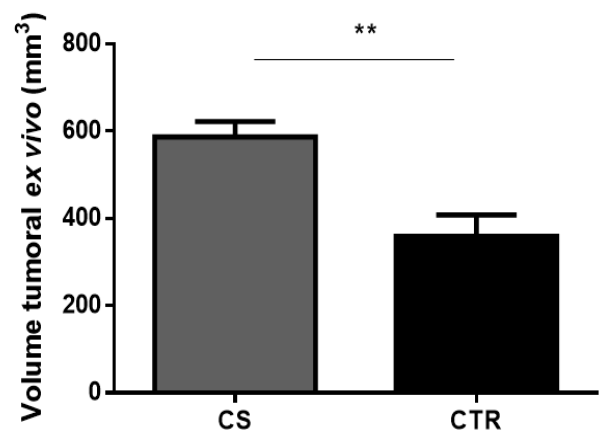

C

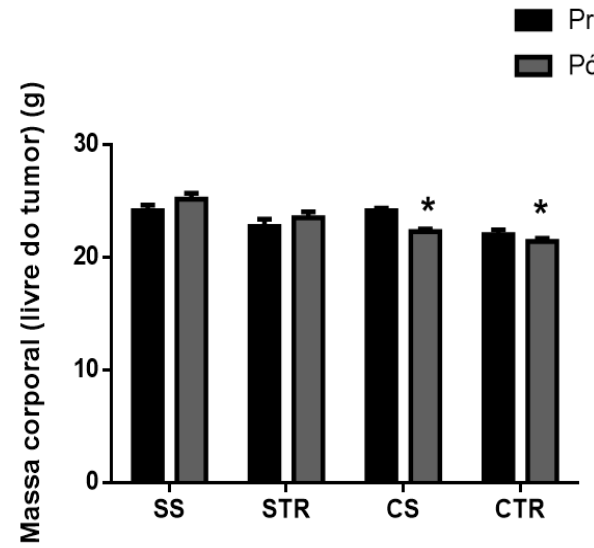

B

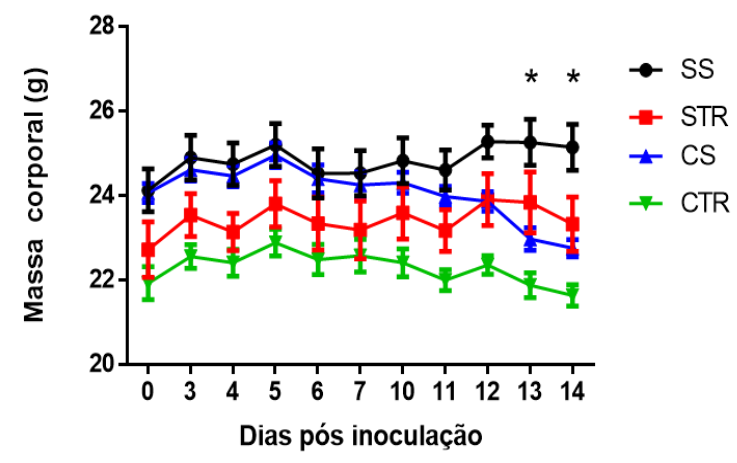

D

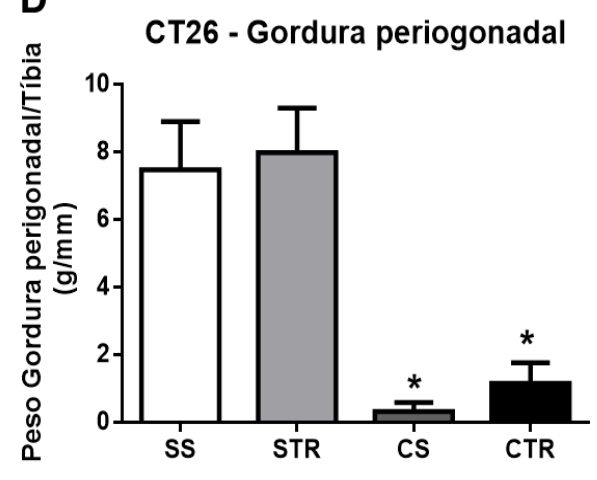

Figura 15: A) Volume tumoral ex vivo B) Massa corporal total C) massa corporal livre do tumor D) Peso da gordura perigonadal. Controle Saudável Sedentário (SS), Saudável Treinado (STR); Câncer Sedentário (CS); Câncer Treinado (CTR); ${ }^{*} p<0,05 ;{ }^{* *} p<0,01$.

Vimos também que o peso dos músculos sóleo e plantar não alteram em virtude do câncer, entretanto os músculos gastrocnêmio e tibial anterior mostram diminuição do peso nos animais CS e CTR. O treinamento causa uma menor perda do peso do músculo gastrocnêmio comparando os grupos CS e CTR; esse resultado foi encontrado somente nesse músculo (Figura 16A). Apesar do treinamento físico não ser capaz de frear a perda do peso do músculo tibial anterior decidimos continuar nossos experimentos com esse 
tecido, pois já havíamos conduzido o estudo 1 com o mesmo e, também, porque o câncer causou perda da massa muscular independente da condição de treinamento.

Esses dados mostrado até agora mostram que os animais do grupo CS e CTR do modelo CT26 de fato apresentam caquexia. Passamos então a avaliar medidas funcionais desses animais, realizamos o teste de preensão. Observamos que os animais CS apresentam perda de força, os animais do grupo CTR também perdem força e não são diferentes do grupo CS. Os animais do grupo STR não são diferentes do controle, mostrando que o treinamento aeróbico não causa melhoras nessa capacidade nos indivíduos saudáveis (Figura 16B). Estes resultados são esperados para o grupo STR, pois indivíduos saudáveis não teriam grandes ganhos na função muscular após treinamento físico aeróbico. Entretanto, esperávamos que esse treinamento prevenisse a perda da função muscular em indivíduos com câncer, o que não se confirmou.

A

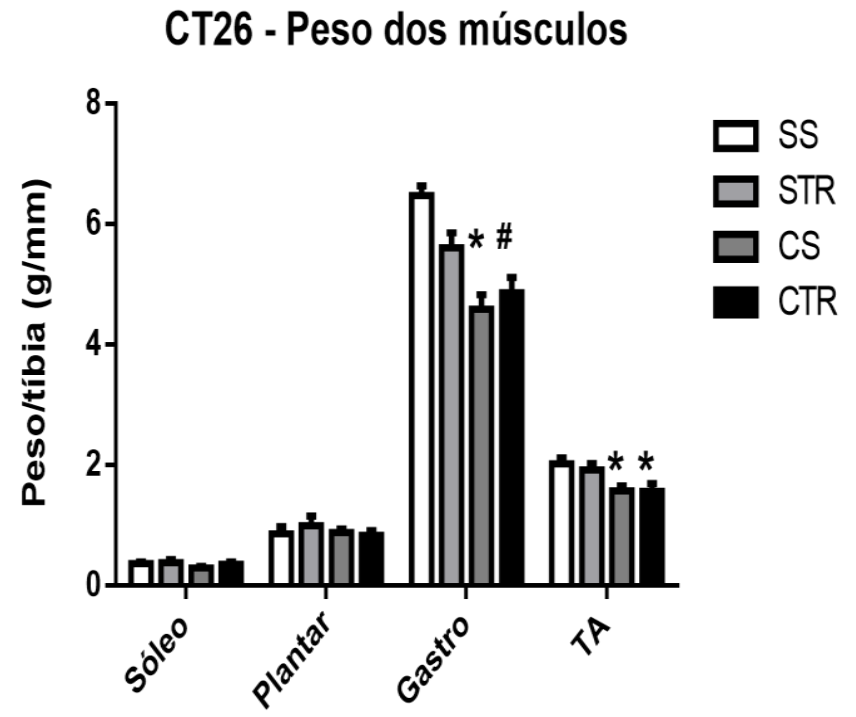

B

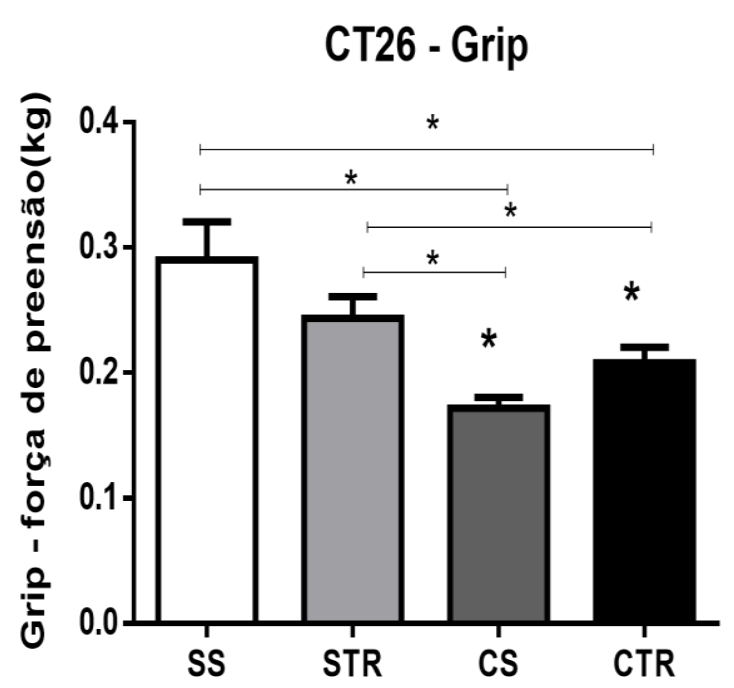

Figura 16: A) Peso dos músculos sóleo, plantar, gastrocnêmio e Ftibial anterior B) Grip- força de preensão. Controle Saudável Sedentário (SS), Saudável Treinado (STR); Câncer Sedentário (CS); Câncer Treinado (CTR); * $p<0,05$; \# $\mathrm{p}<0,05$ vs CS. 


\subsubsection{MicroRNAs}

Analisamos a expressão do microRNA-206 no músculo tibial anterior e observamos que há um aumento da expressão nos grupos CS e CTR quando comparados com o grupo SS; o grupo STR não difere do grupo SS (Figura 17A). Observamos também que a expressão do microRNA-486 está diminuída nos grupos CS e CTR não havendo diferença entre eles, o grupo STR apresenta mesmo nível de expressão do grupo SS, mostrando que o treinamento não influencia a expressão desses microRNAs (Figura 17B).

A

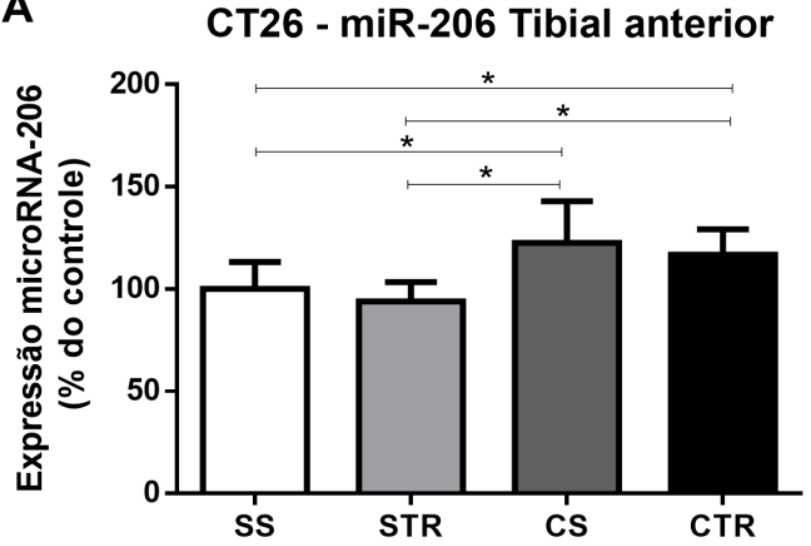

B

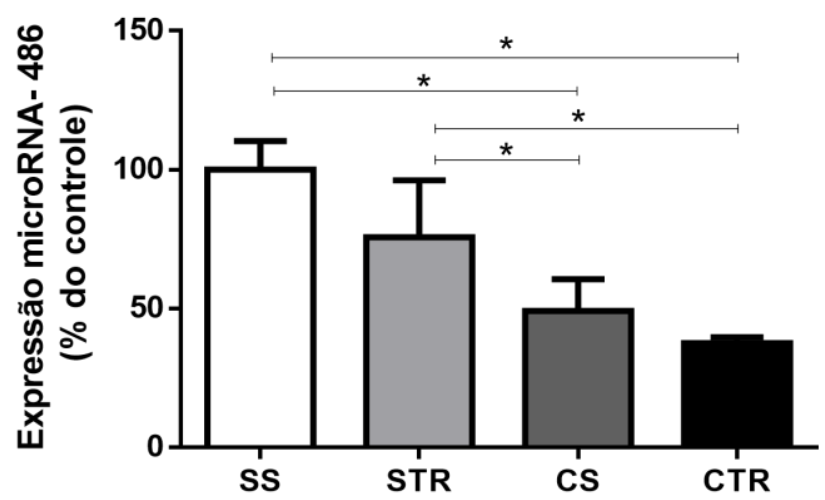

Figura 17: A) Expressão do microRNA-206 no tibial anterior B) Expressão dos microRNA-486 no tibial anterior. Controle Saudável Sedentário (SS), Câncer Sedentário (CS); Câncer Treinado (CTR). * $p<0,05$.

A expressão do microRNA-206 na circulação mostra que há uma diminuição da expressão quando comparado com o grupo SS, os animais do grupo CTR apresentam uma tendência a diminuição, mas estatisticamente não é diferente do grupo SS. O grupo STR não difere do grupo SS (Figura 18A). Analisando a expressão do microRNA-486, observamos que há uma severa diminuição da expressão desse microRNA na circulação em decorrência do câncer e do treinamento físico. Os grupos CS, CTR e STR apresentam o mesmo padrão de expressão (Figura 18B). 
A

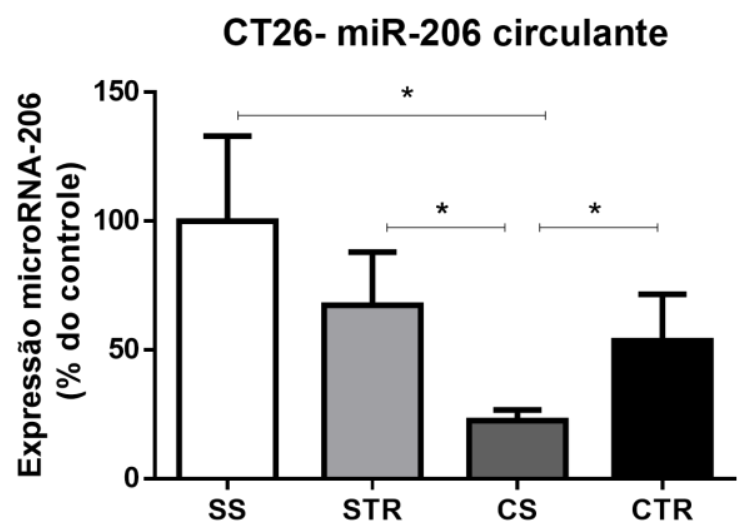

B CT26 - miR-486 circulante

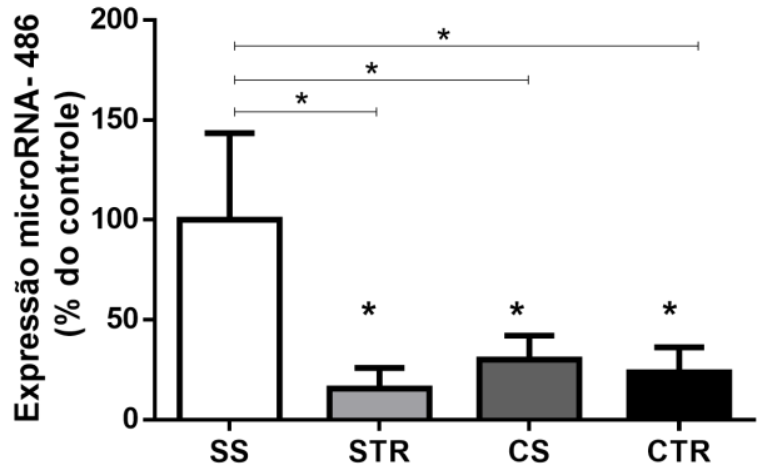

Figura 18: A) Expressão dos microRNA-206 na circulação B) Expressão dos microRNA-486 na circulação. Controle Saudável Sedentário (SS), Câncer Sedentário (CS); Câncer Treinado (CTR). * $p<0,05$.

\subsubsection{Expressão Proteica}

Analisamos a expressão da proteína PI3K, a qual se encontra diminuída nos grupos CS e CTR, sugerindo um prejuízo nas vias de síntese proteica (figura 19B) O exercício físico não contribuiu para amenizar o normalizar o fenômeno observado. A proteína AKT nos nossos resultados não tem a expressão alterada em nenhum dos grupos (figura 19A), também a proteína mTOR não apresenta diferença estatística entre os grupos CS e CTR comparado com o controle SS, entretanto o grupo STR apresenta aumento de expressão comparado com os grupos (figura 19C).

Analisamos a expressão da proteína PTEN (alvo do microRNA-486). Mostramos em nossos resultados que a expressão desta proteína esta aumentada no grupo CS e CTR, indo ao encontro dos resultados observados sobre a expressão do microRNA-486 no tibial anterior que está diminuído no mesmo grupo (figura 19D). Esses dois resultados em conjunto sugerem um aumento nas vias de degradação proteica nos animais com câncer, e que o exercício físico não é capaz de amenizar esse fenômeno. Apesar de não haver diferença entre a expressão das proteínas FOXO3a e pFOXO3a entre os grupos (Figura 18E e 18D, respectivamente). 
A

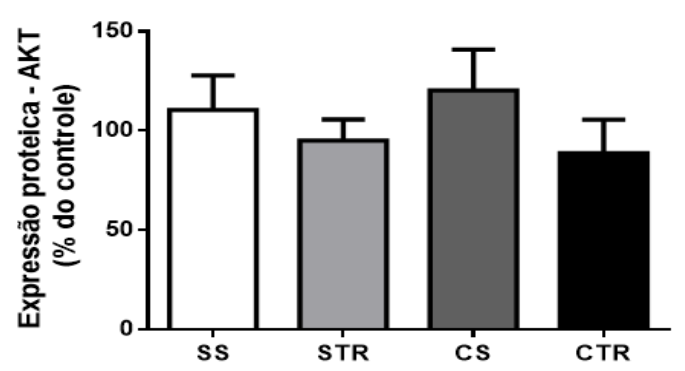

C

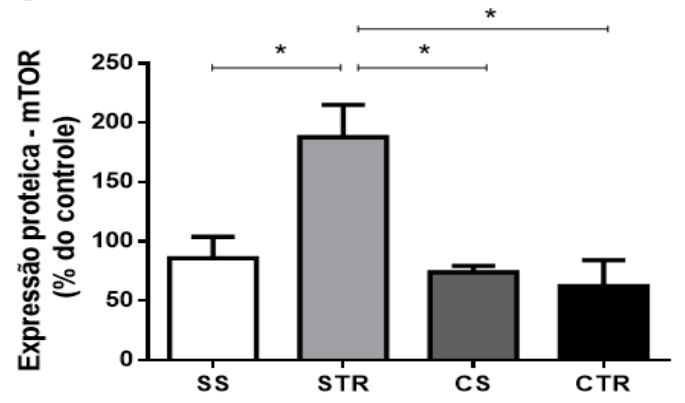

$\mathbf{E}$

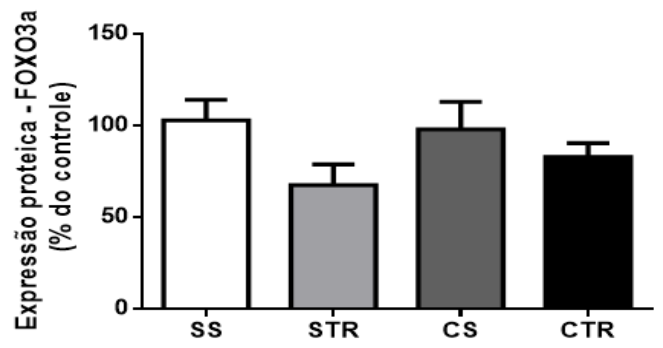

B
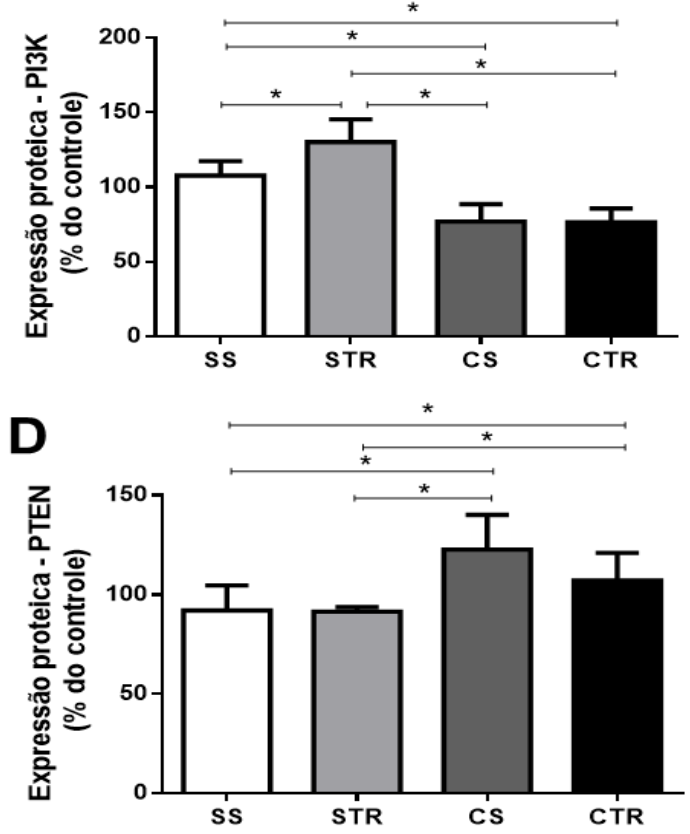

$\mathbf{F}$

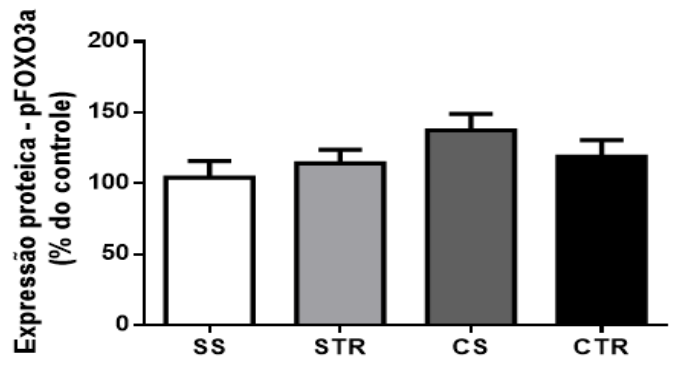

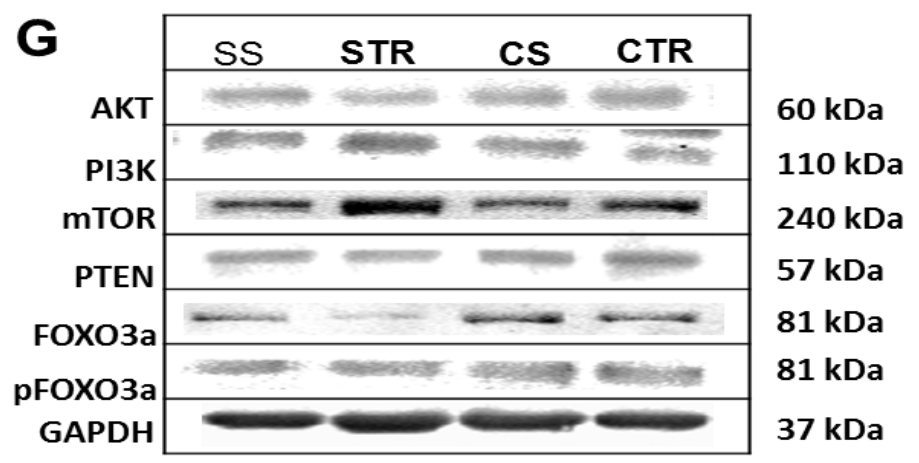

Figura 19: A) Expressão da proteína AKT B) Expressão da proteína PI3K C) Expressão da proteína mTOR D) expressão da proteína PTEN E) Expressão da proteína FOXO3a F) Expressão da proteína pFOXO3a G) imagem representativa das bandas de proteína. Controle Saudável Sedentário (SS), 
Saudável Treinado (STR); Câncer Sedentário (CS); Câncer Treinado (CTR). * $\mathrm{p}<0,05$.

A proteína PAX7 e PAX3 alvos do microRNA-206 não tiveram alteração entre os grupos (Figura 20B e 20C, respectivamente). Também não houve diferença na expressão da proteína HDAC, outro alvo do microRNA-206.

A

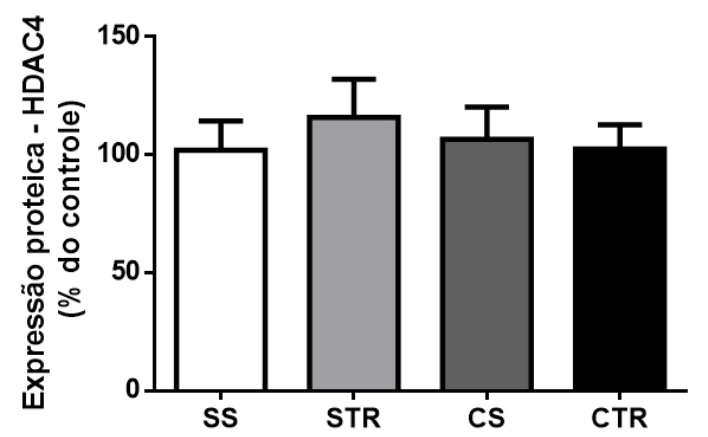

C

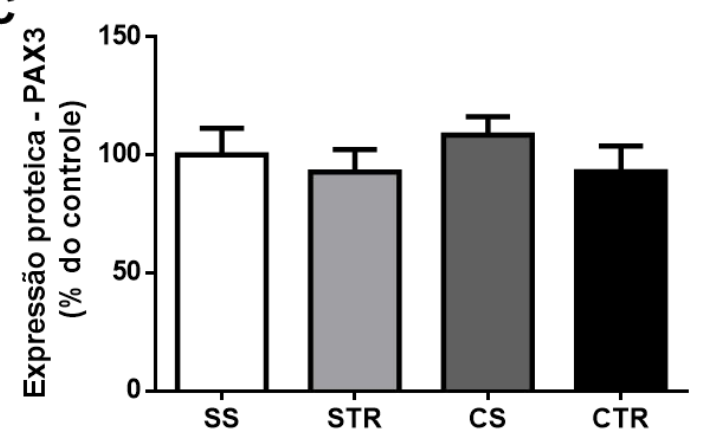

B

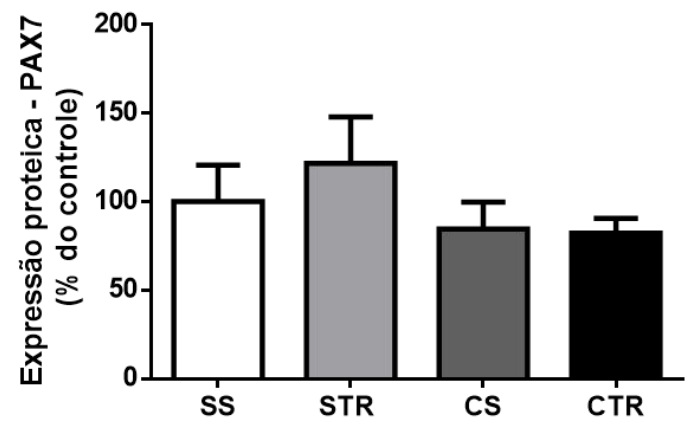

D

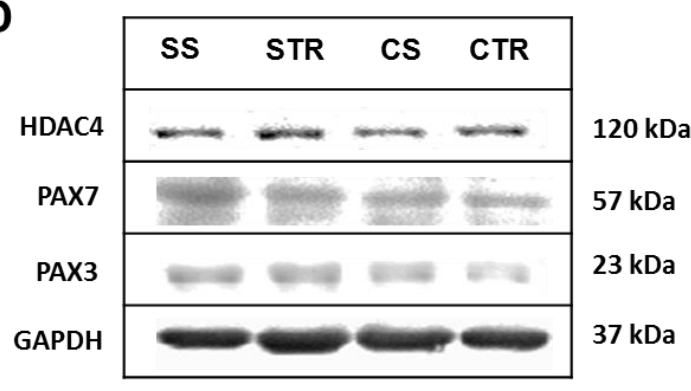

Figura 20: A) Expressão da proteína HDAC4 B) Expressão da proteína PAX7 C) Expressão da proteína PAX3 D) imagem representativa das bandas de proteína. Controle Saudável Sedentário (SS), Saudável Treinado (STR); Câncer Sedentário (CS); Câncer Treinado (CTR). * $p<0,05$.

\section{Discussão dos resultados}

O câncer apresenta alta prevalência e gera um grande número de mortes no mundo todo, as pesquisas sobre essa doença têm progredido sobremaneira. Assim, com o avanço dos estudos sobre câncer, novas terapias vem sendo amplamente propostas, principalmente em relação às comorbidades associadas a doença, incluindo as agressões geradas contra 0 músculo esquelético. O músculo esquelético é um tecido fundamental para o controle do metabolismo, confere sustentação e propicia locomoção, somado a 
isso, as injurias ao músculo esquelético estão atreladas a piora do quadro de diversas doenças, incluindo o câncer (Carson, Hardee, \& VanderVeen, 2015).

Não há na literatura uma caracterização da musculatura esquelética do modelo MMTV-PyMT, somos os primeiros a demostrar o fenótipo muscular desse modelo. Também investigamos o papel do exercício físico aeróbico no modelo MMTV-PyMT e no modelo de caquexia CT26, uma vez que que o exercício físico já foi demonstrado como responsável por mudanças adaptativas benéficas na morfologia muscular esquelética (Ruas et al., 2012), sendo assim, investigamos o papel do exercício físico aeróbico como uma possível terapia na prevenção das injurias musculares acarretadas pelo câncer. Além disso, não há na literatura uma caracterização da expressão myomiRs em animais do modelo MMTV-PyMT e CT26 submetidos à um protocolo de treinamento físico aeróbico. Os myomiRs por sua vez são microRNAs com expressão enriquecida na musculatura esquelética e cardíaca e que agem controlando a miogênese, trofismo e metabolismo muscular (Horak et al., 2016).

Sobre os resultados do nosso trabalho destacamos:

Os animais sedentários com câncer apresentam grande prejuízo no teste de esforço máximo e aumento no conteúdo de gordura corporal no modelo MMTV, sugerindo dessa forma um prejuízo metabólico que por sua vez é prevenido com o treinamento físico. Entretanto o treinamento não tem $o$ mesmo papel no modelo CT26, tanto os animais do grupo CS e CTR perdem a capacidade de resistir ao esforço, muito embora os animais do grupo CS perderam essa capacidade antes do grupo CTR; Ambos animais do grupo CS e CT do modelo CT26 perdem muito do conteúdo de gordura e massa corporal de modo geral; dessa forma os efeitos da caquexia nesse modelo é freado pelo exercício físico aeróbico, mas de forma breve.

A literatura demonstra que a diminuição da capacidade aeróbica é um forte preditor para de mortalidade (Kodama et al., 2009). Nossos resultados mostrando que os indivíduos com câncer têm prejuízo na resposta ao esforço estão de acordo com a literatura. NEIL-SZTRAMKO et al., 2014 mostraram que em mulheres com câncer de mama a capacidade aeróbica e força dos membros superiores é severamente diminuída antes, durante e depois do 
tratamento, além do fato da diminuição da capacidade aeróbica ser independente da idade. Esse prejuízo na capacidade aeróbica pode estar vinculado com o desenvolvimento de outras comorbidades.

Contrário a isso, o exercício surge como terapia contrarreguladora à essas desordens. Alguns estudos têm demonstrado o efeito do treinamento físico no combate a fadiga e perda de força em mulheres com câncer de mama. REIS et al., 2013 mostraram que 12 semanas de exercício em pacientes com câncer de mama foram eficientes em aumentar a capacidade aeróbica e a qualidade de vida.

Entretanto a redução da capacidade aeróbica está presente não só no câncer de mama, mas como em outros diversos tipos de câncer. Por essa razão LAGO et al., 2011 propõe uma revisão sobre o papel de p53 no metabolismo e no câncer. P53 é uma proteína que regula o ciclo celular, ela está vinculada com a estabilidade genômica, entretanto em diversos tipos de câncer a sua expressão é diminuída, permitindo o desenvolvimento da doença. P53 também está relacionada com o metabolismo, pois ela é uma supressora de vias anaeróbicas e reguladora da respiração mitocondrial. Dessa forma tumores que apresentem diminuição na expressão de p53 estão diretamente ligados a diminuição do metabolismo oxidativo. As alterações metabólicas no tumor podem influenciar o metabolismo de forma global, dessa forma possíveis alterações no metabolismo oxidativo levam a diminuição da capacidade de resistir ao esforço.

Sobre o papel do exercício físico modulando o tumor nós não encontramos resultados significativos o modelo MMTV, mas no modelo CT26 observamos um menor crescimento tumoral nos animais submetidos ao treinamento físico. Não é consenso na literatura que o exercício físico aeróbico modula a morfologia do tumor. Alguns trabalhos mostram que o exercício físico tem um importante papel na diminuição do volume tumoral, mas nem sempre os controles dos métodos são rígidos o bastante para que esse resultado possa ser generalizado (Betof et al., 2015a). Outros trabalhos mostram que não há efeito do exercício físico aeróbico na regulação do volume tumoral (Betof et al., 2015a). Entretanto outros estudos mostram que o treinamento físico aeróbico leva a diminuição do volume tumoral ou retarda o 
crescimento (Betof et al., 2015b), recentemente PEDERSEN et al., 2016 mostrou de modo mais contundente que o volume tumoral pode ser regulado pela atividade física voluntária.

No modelo MMTV PyMT os pesos dos músculos esqueléticos e as medidas histológicas não apresentaram alterações em decorrência do câncer, entretanto o câncer de mama não é notoriamente um gerador de caquexia (Chen et al., 2014), dessa forma não esperávamos grandes alterações na massa muscular. Entretanto, apesar dos poucos estudos, a literatura sugere que o músculo esquelético pode ser afetado de outras formas pelo câncer de mama. Um estudo de CHEN et al., 2014 mostrou que no músculo esquelético e no músculo cardíaco de camundongos com câncer de mama MMTV-PyMT havia uma diminuição acentuada de AKT fosforilada, que é uma proteína importante que regula síntese proteica e a manutenção da massa e, em contrapartida, havia um aumento acentuado de FOXO1a e PTEN, que são proteínas relacionadas com a degradação proteica e atrofia. Os autores mostraram que além da alteração das vias de síntese e degradação proteica também havia uma redução na expressão de fatores miogênicos como a MyoD, importante para a proliferação e formação das fibras muscular, sugerindo um prejuízo no desenvolvimento miogênico induzido pelo câncer de mama. Embora o estudo não relatasse atrofia da musculatura esquelética desses animais até a data do sacrifício, eles apresentavam um quadro de "précaquexia", sendo provável que eles viessem a desenvolve-la, tendo em vista as alterações moleculares e sabendo que a caquexia tem vários níveis. Os nossos resultados no mesmo modelo observamos que há diminuição da expressão de AKT e PI3K sugerindo que as vias de síntese estejam prejudicadas, mas sem acarretar na morfologia do músculo esquelético até a idade em que os animais foram sacrificados. Entretanto a proteína PTEN e FOXO1a ao contrário do estudo supracitado não apresenta diferença entre os nossos grupos. Dessa forma, nossos dados vão de encontro com os encontrados na literatura, sugerindo que a musculatura esquelética não sofre danos em decorrência do câncer de mama, acreditamos que apesar de haverem alterações moleculares na expressão proteica das vias de síntese e na expressão de microRNAs que controlam vias de degradação (esses dados 
serão discutidos em um próximo momento), essas mudanças apesar de indicar um prejuízo na musculatura esquelética não apresentam grande poder para gerar um efeito biológico. O exercício físico foi incapaz de influenciar na expressão das proteínas que estudamos.

O modelo CT26 que apresenta notória caquexia, nós encontramos uma diminuição no peso e função dos músculos esqueléticos; o músculo sóleo e plantar se mostraram preservados, mas o músculo tibial anterior e gastrocnêmio apresentaram perda de peso. O exercício físico só foi capaz de preservar parcialmente a massa muscular do músculo gastrocnêmio, mas não foi capaz de preservar a função. Analisando a expressão proteica observamos que PTEN se mostra aumentada nos animais com câncer sedentários e treinados, essa proteína influencia a degradação muscular, como observamos a perda da massa e função podemos deduzir que nesse modelo as vias de degradação proteica estejam aumentada em comparação a vias de síntese; muito embora outras proteínas relacionadas com as vias de degradação que analisamos tal como FOXO3a e pFOXO3a não estavam apresentaram diferença entre os grupos. Das proteínas da via de síntese somente PI3K apresentou diminuição em virtude do câncer tanto nos grupos sedentários quanto treinados, enquanto AKT e mTOR se mostram preservadas. Dessa forma, apesar de observarmos que há indícios de aumento da degradação proteica, acreditamos que a perda da massa muscular e da função é influenciada por outras vias que não analisamos.

Acreditamos, também, que o treinamento físico aeróbico não foi o bastante para influenciar mudanças no trofismo muscular dos animais caquéticos CT26; esse tipo de treinamento já foi descrito em outras doenças como um meio de preservação da massa muscular frente as injurias de diversas doenças tais como hipertensão e obesidade (Fernandes et al., 2012; Frisbee et al., 2014). No câncer de colón, recentemente, foi demonstrado que somente o treinamento resistido foi capaz de sofrear a perda da massa muscular nos animais caquéticos e esse resultado, apesar de significativo, não apresenta uma total preservação da massa muscular (Jo \& Salazar, 2016). Nesse mesmo trabalho os autores demonstraram que o treinamento resistido previne a diminuição da expressão de proteínas como mTOR, IGF e 
miogenina e o treinamento aeróbico não influenciou na expressão dessas proteínas relacionadas com a síntese proteica.

Sobre a expressão dos microRNAs observamos que os myomiRs apresentam alterações na expressão, apesar de mostrarmos que o músculo esquelético do modelo MMTV-PyMT se mostra preservado contra as agressões do câncer, não havendo prejuízos na perda de massa e função muscular, área de secção transversa e tipagem de fibras.

Entretanto, observamos que a expressão tem um comportamento bastante heterogêneo entre os animais, mas de toda forma não apresenta um papel fundamental no controle da massa e função muscular, este é o caso do microRNAs-1, -133a e -133b. Os microRNAs-206 e -486 se mostram alterados no modelo MMTV PyMT; o primeiro se encontra aumentado no grupo CS e CTR entretanto apesar de observarmos alterações na expressão desses microRNAs não há indícios de prejuízo no músculo, o que impossibilita uma leitura precisa dos dados.

O microRNA-206 está fortemente relacionado com o desenvolvimento e regeneração muscular, especificamente há um notável aumento da expressão destes durante a diferenciação de mioblatos. A elevada expressão destes microRNAs neste período está relacionada com a interrupção da proliferação celular e início da fase de diferenciação; dessa forma esse microRNA está relacionado com regeneração muscular uma vez que a diferenciação muscular e inibição da proliferação permite formar miócitos maduros e que podem exercer função. Estudos inibindo a expressão do mesmo mostram a importância deste em diminuir a fase proliferativa e permitir que desenvolvimento de mioblastos se inicie (Goljanek-Whysall et al., 2012).

Após uma injuria no músculo esquelético ocorre a diminuição na expressão do microRNAs-206 e um concomitante aumento da proliferação celular, esses fenômenos são sucedidos por um grande aumento na expressão do microRNA-206 e também microRNA-1; este processo está relacionado com o balanço entre proliferação e diferenciação celular que tem como resultado final a regeneração muscular. O microRNA-206 participam de modo importante no processo de miogênese e muitos dos seus alvos estão envolvidos em vias de proliferação e diferenciação, os principais alvos desse 
microRNA são as proteínas HDAC4 (do inglês histone deacetylase 4), PAX3 (do inglês Paired Box 3) e PAX7 (do inglês paired box 7) (Horak et al., 2016).

A importância desse microRNA durante o processo de regeneração muscular pode ser observada em um estudo de Liu e seus colaboradores que promoveram a deleção do microRNA-206 e submeteram os animais a lesões musculares e a regeneração muscular foi significativamente diminuída (Liu et al., 2012). O aumento da expressão desse microRNAs no câncer é um sinal de dano muscular ocasionado pela doença, entretanto no nosso trabalho nós não observamos prejuízos na morfologia e na função do músculo esquelético do modelo MMTV, apesar de haver uma expressão aumentada do microRNA206 no músculo esquelético; no modelo CT26 onde há caquexia muscular o aumento da expressão do microRNA-206 ocorre como o esperado.

Entretanto ao analisarmos a expressão proteica desses alvos que citamos; vimos que não há diferença entre os grupos tanto no modelo MMTVPyMT e CT26. Nós não analisamos a expressão genica de HDAC4, PAX3 e PAX7 dessa forma, não podemos afirmar que a expressão do mRNA que são traduzidos nessas proteínas está alterada e se existem outros mecanismos de controle da expressão genica e proteica além do microRNA-206. Em futuras investigações se faz necessário estudar a relação dos microRNAs com outros fatores que podem controlar a expressão e a função dos mesmo, por exemplo, a interação microRNA com IncRNA (do inglês long non conding RNA) que podem apresentar sítios de ligação para os microRNAs que competem com os sítios de ligação do RNAm alvo (Yuan et al., 2014), tal como a relação entre microRNAs com outros genes alvos e os priprios controles endógenos da biogênese (Miyoshi, Miyoshi, \& Siomi, 2010).

Este microRNA também agem no controle do crescimento celular. Em estudo de $\mathrm{Li}$ e seus colaboradores foi observado o envolvimento dos microRNAs -1 e -206 na regulação do ciclo celular através da inibição das proteínas CCND2 (ciclina D2) e CCND1 (ciclina D1) indispensáveis fatores para a progressão do ciclo celular (Li, Sarver, Alamgir, \& Subramanian, 2012). A supressão dessas proteínas tem um efeito anti- proliferativo e dessa forma ocasionando a inibição do crescimento muscular e sugere-se um papel específico desses microRNAs na diminuição do ciclo celular durante o 
processo de diferenciação. Células musculares com diminuída expressão do microRNA-206 resultam no aumento de fatores anti-apoptóticos inibindo a morte celular (Horak et al., 2016). Dessa forma o aumentos do microRNA-206 no músculo esquelético de animais câncer também sugere que o crescimento muscular está sendo prejudicado, entretanto não encontramos os mecanismos efetores desse fenômeno.

$\mathrm{Na}$ caquexia esse microRNA já foi descrito como aumentado (Camargo et al., 2015). Nós encontramos no músculo esquelético do modelo CT26 a expressão desse microRNA aumentada no grupo CS, entretanto o exercício físico teve influência na expressão desse microRNA.

No trabalho de Chen e colaboradores foi observado que a expressão do microRNAs-486 é diminuída no músculo esquelético de animais MMTV-PyMT (CHEN et al., 2014). Este microRNA participa de modo efetivo na miogênese alvejando diretamente a proteína PAX7, dessa forma interrompendo a proliferação e aumenta o processo de diferenciação muscular. Entretanto a função mais reconhecida desse microRNA é controlar o trofismo muscular. Este tem um importante papel na via de PI3K/AKT por alvejar diretamente os genes das proteínas PTEN e FOXO1a (SMALL et al., 2010), promovendo dessa forma controle da degradação proteica. Há através desse processo também um controle da viabilidade do ciclo celular e aumento da migração celular.

A diminuição da expressão do microRNA-486 em mioblastos normais resulta na impossibilidade da migração e da fusão celular, por outro lado uma super expressão gera regeneração muscular. Em indivíduos distróficos a expressão deste microRNA é extremamente baixa, e estudos realizados com animais distróficos demostraram que a super expressão deste microRNA promove aumente da função e força muscular (ALEXANDER et al., 2014).

O microRNA-486 não é exclusivamente expresso na musculatura esquelética, mas é muito enriquecido nesse tecido, dessa forma também sendo considerado um myomiR. Nos nossos dois modelos animais (MMTV e CT26) nós encontramos uma baixa expressão deste microRNA no músculo esquelético dos animais com câncer sendo sedentários ou treinados. Entretanto olhando a expressão proteica de PTEN não observamos aumento 
no modelo MMTV, mas no modelo CT26 ocorre de acordo com o esperado. Como no modelo MMTV o resultado se opõe ao esperado, se faz preciso investigar outros mecanismos que estão preservando o trofismo muscular.

Dos microRNAs que estudamos além do microRNA-486, também microRNA-206 já foi avaliada sua expressão no músculo esquelético de outro modelo animal com câncer de mama. Nossos dados sobre esse microRNA estão de acordo com os resultados apresentados na literatura, a literatura sugere que existe um alterações na expressão desses microRNAs em decorrência do câncer e também em decorrência do treinamento, apesar de não haver alterações na massa e função muscular (Isanejad et al., 2016).

Sobre os demais microRNAs, 1 -133a e -133b que avaliamos somente no modelo MMTV PyMT, não há evidências da expressão deles no músculo esquelético em modelos de câncer. Entretanto existem vários registros da expressão do mesmo em outras doenças e em decorrência do treinamento físico. No nosso trabalho os microRNAs mostraram uma tendência estatística de diminuição nos grupos treinado CTR e STR e os animais do grupo CS mostram tendência de aumento, esses resultados acompanham os dados da literatura onde é encontrado que o treinamento diminui a expressão destes e em muitos quadros patológicos há o aumento dos mesmos (Calvano et al., 2015; Carè et al., 2007; Luo et al., 2015; Mooren et al., 2014; Townley-Tilson, Callis, \& Wang, 2010; Yu et al., 2014).

A literatura aponta que os microRNAs -133a e -133b apresentam um papel ambíguo na miogênese atuando em vias de proliferação e diferenciação variando sua expressão de acordo com o contexto; (HORAK; NOVAK; BIENERTOVA-VASKU, 2016). A supressão da proliferação de mioblastos e aumento da diferenciação ocorre através da regulação da proteína MAPK (do inglês mitogen-activated protein kinase); os microRNAs-133a 133b por sua vez levam a diminuição indireta de MAPK. A inibição da via de MAPK leva a formação de miotúbulos extremamente pequenos. Dessa forma MAPK é importante nas fases preliminares da miogênese, esta proteína permite a acumulação de mioblatos o bastante para se fundirem e formarem miotúbulos funcionais. 
Entretanto um estudo de Luo e seus colegas demostrou que a super expressão do microRNA-133a em células musculares C2C12 geram um significante aumento da formação de miotúbulos; um dos possíveis mecanismos para que ocorra esse fenômeno é a ligação do microRNA com a proteína FOXL2 (do inglês forkhead box L2), esse alvo age no controle negativo da proteína MyoG proteína responsável pela diferenciação celular, ou seja, o microRNA 133a diminui a expressão de FOXL2 levando ao aumento indireto de MyoG (LUO et al., 2015).

A literatura mostra também que animais knockout para o microRNA133a apresentam severas miopatias, com disfunção mitocondrial, problemas na morfologia das miofibras, morte celular e mudanças expressivas do tipo de fibra para tipo I (LIU et al., 2012). Por outro lado, a super expressão do microRNA-133a somado aos microRNAs-1 e -206, injetados no músculo esquelético de camundongos após sofrerem danos musculares levou ao aumento indireto das proteínas MyoG, MyoD e PAX7 aumentando a regeneração muscular e prevenindo fibrose (NAKASA et al., 2010).

Sendo assim os microRNAs-133a e -133b influenciam diretamente na miogênese. Muito embora, como dito anteriormente, de modo ambíguo e variando de acordo com o contexto. No músculo esquelético de animais com câncer o seu papel ainda não foi descrito. No nosso trabalho observamos uma tendência de aumento da expressão desses microRNAs, mas não podemos afirmar qual o papel que estes estão desempenhado na musculatura esquelética de animais com câncer.

A expressão do microRNAs-206 na circulação dos animais do modelo CT26 e MMTV mostram comportamentos antagônicos, no primeiro modelo, mMTV, a expressão está aumentada na circulação dos animais com câncer, no segundo modelo, CT26, a expressão está diminuída nos animais com câncer. A expressão do microRNA-486 tem o mesmo padrão de expressão nos dois modelo, mostrando diminuição nos animais com câncer sedentários e treinados, este comportamento já foi descrito na literatura (Chen et al., 2014). Analisamos a expressão total desses microRNAs no soro, dessa forma medidos o conteúdo que provem de corpos apoptóticos celulares, microvesículas e outras fontes, este dado dessa forma não pode ser 
interpretado como um possível mecanismo com função biológica, mas indica que o músculo esquelético apresenta injurias. Dessa forma, esses microRNAs servem como marcadores destas injurias, entretanto os mecanismos moleculares que estão envolvidos com essa expressão diferenciada desses microRNAs ainda não são conhecidos.

De modo geral os resultados dão indícios que os microRNAs podem estar relacionados com prejuízos na musculatura esquelética em virtude do câncer; o estudo que fizemos em um modelo não caquético (MMTV PyMT) nos mostrou que mesmo sem perda de massa muscular e função alguns myomiRs apresentam expressão alterada indicam um estado anterior ao dano muscular. Tínhamos com estratégia estudar esses animais com uma idade mais avançada e averiguar se ocorre de fato prejuízos na massa muscular, mas lidando com os animais percebemos que não seria possível, pois se os animais fossem mais velhos os tumores teriam um tamanho muito grande, os animais teriam dificuldade em se locomover e além de apresentarem ulcerações. Dessa forma, teríamos resultados falsos e incompatíveis com a ética do trabalho com animais.

Dessa forma, nossa estratégia foi adotada para ter respostas mais contundentes foi usar um modelo caquético robusto, CT26.

Os resultados mostram que os myomiRs alterados no modelo MMTV também estão alterados no modelo CT26. Entretanto precisamos de mais respostas sobre a expressão proteica e genica de outras vias relacionadas com síntese e degradação no músculo esquelético, pois mostramos alterações nos microRNAs, mas não observamos alterações muito significativas nos seus alvos, salvo guardando a expressão do microRNA-486 e da proteína PTEN no modelo CT26. Os microRNAs circulantes apresentaram um comportamento diferente entre os grupos, a alteração na expressão desses microRNAs circulantes indicam injurias no musculo esquelético, principalmente no modelo CT26, entretanto esses resultados reforçam a ideia de que novos estudos devem ser conduzidos, pois os microRNAs circulantes nos servem como biomarcadores, mas ainda se faz preciso mostrar os mecanismos moleculares que os mesmo estão relacionados. 


\subsection{Resumo dos resultados e conclusão.}

Observamos que os animais do modelo MMTV não apresentaram perda da função e massa muscular, entretanto dois myomiRs, miR-206 e 486, tem a expressão alterada no músculo esquelético e na circulação em função do câncer e o exercício físico não influencia na expressão dos mesmos. No nosso trabalho ainda precisamos avaliar a expressão proteica dos outros alvos desses microRNAs, mas observamos que a expressão das proteínas AKT e PI3K está diminuída por conta do câncer, não havendo influência do exercício físico.

Ainda avaliamos os mesmos parâmetros no modelo CT26, um modelo descrito como caquético na literatura. Nesse modelo os animais apresentavam perda de função e massa muscular, A expressão dos myomiRs-206 e 486 também está alterada na circulação e no musculo esquelético e o exercício físico não influencia a expressão destes microRNAs, tal como no modelo MMTV. Nesse modelo a expressão da proteína PI3K está diminuída e de PTEN está aumentada em função do câncer.

Importante salientar que nos dois modelos os animais com câncer apresentam perda da capacidade aeróbica, e o exercício físico só é capaz de reverter esse quadro no modelo MMTV.

Podemos concluir com os dados apresentados até o momento que os microRNAs 206 e 486 tem a expressão alterada no tecido muscular e na circulação em decorrência do câncer, independente da caquexia, e, são marcadores de prejuízos nas vias de síntese proteica no tecido muscular. Ainda é necessário analisar outras proteínas e genes alvos, principalmente das vias de degradação proteica, para confirmar se esses microRNAs estão relacionados com prejuízos na massa e função muscular.

\section{Referência}

Acharyya, S., Butchbach, M. E. R., Sahenk, Z., Wang, H., Saji, M., Carathers, M., ... Guttridge, D. C. (2005). Dystrophin glycoprotein complex dysfunction: A regulatory link between muscular dystrophy and cancer 
cachexia. Cancer Cell, $\quad$ 8(5), $421-432$. https://doi.org/10.1016/j.ccr.2005.10.004

Ahima, R. S., \& Park, H. K. (2015). Connecting Myokines and Metabolism. Endocrinology and Metabolism (Seoul, Korea), 30(3), 235-45. https://doi.org/10.3803/EnM.2015.30.3.235

Ambros, V. (2001). microRNAs: Tiny regulators with great potential. Cell, 107(7), 823-826. https://doi.org/10.1016/S0092-8674(01)00616-X

Anderson, W. F., Rosenberg, P. S., Prat, A., Perou, C. M., \& Sherman, M. E. (2014). How many etiological subtypes of breast cancer: Two, three, four, or more? Journal of the National Cancer Institute, 106(8), 1-11. https://doi.org/10.1093/jnci/dju165

Baggish, A. L., Park, J., Min, P.-K., Isaacs, S., Parker, B. A., Thompson, P. D., ... Chan, S. Y. (2014). Rapid upregulation and clearance of distinct circulating microRNAs after prolonged aerobic exercise. Journal of Applied Physiology (Bethesda, Md.: 1985), 116(5), 522-31. https://doi.org/10.1152/japplphysiol.01141.2013

Betof, A. S., Lascola, C. D., Weitzel, D., Landon, C., Scarbrough, P. M., Devi, G. R., ... Dewhirst, M. W. (2015a). Modulation of murine breast tumor vascularity, hypoxia and chemotherapeutic response by exercise. Journal of the National Cancer Institute, 107(5), 1-5. https://doi.org/10.1093/jnci/djv040

Betof, A. S., Lascola, C. D., Weitzel, D., Landon, C., Scarbrough, P. M., Devi, G. R., ... Dewhirst, M. W. (2015b). Modulation of murine breast tumor vascularity, hypoxia and chemotherapeutic response by exercise. Journal of the National Cancer Institute, 107(5). https://doi.org/10.1093/jnci/djv040

Brown, D. M., \& Goljanek-Whysall, K. (2015). microRNAs: Modulators of the underlying pathophysiology of sarcopenia? Ageing Research Reviews, 24, 263-273. https://doi.org/10.1016/j.arr.2015.08.007

Calvano, J., Achanzar, W., Murphy, B., DiPiero, J., Hixson, C., Parrula, C., ... Tirmenstein, M. (2015). Evaluation of microRNAs-208 and 133a/b as differential biomarkers of acute cardiac and skeletal muscle toxicity in rats. 
Toxicology and Applied Pharmacology.

https://doi.org/10.1016/j.taap.2015.11.015

Camargo, R. G., Quintas Teixeira Ribeiro, H., Geraldo, M. V., Matos-Neto, E., Neves, R. X., Carlos Carnevali, L., ... Seelaender, M. (2015). Cancer Cachexia and MicroRNAs. Mediators of Inflammation, 2015. https://doi.org/10.1155/2015/367561

Carè, A., Catalucci, D., Felicetti, F., Bonci, D., Addario, A., Gallo, P., ... Condorelli, G. (2007). MicroRNA-133 controls cardiac hypertrophy. Nature Medicine, 13(5), 613-8. https://doi.org/10.1038/nm1582

Carson, J. A., Hardee, J. P., \& VanderVeen, B. N. (2015). The emerging role of skeletal muscle oxidative metabolism as a biological target and cellular regulator of cancer-induced muscle wasting. Seminars in Cell and Developmental Biology, 54, 53-67. https://doi.org/10.1016/j.semcdb.2015.11.005

Chan, J. A., Krichevsky, A. M., \& Kosik, K. S. (2005). MicroRNA-21 is an antiapoptotic factor in human glioblastoma cells. Cancer Research, 65(14), 6029-6033. https://doi.org/10.1158/0008-5472.CAN-05-0137

Chaun, H. (2010). Sir William Osler and gastroenterology. Canadian Journal of Gastroenterology = Journal Canadien de Gastroenterologie, 24(10), 615-8. Retrieved from http://www.ncbi.nlm.nih.gov/pubmed/21037991

Chen, D., Goswami, C. P., Burnett, R. M., Anjanappa, M., Bhat-Nakshatri, P., Muller, W., \& Nakshatri, H. (2014). Cancer affects microRNA expression, release, and function in cardiac and skeletal muscle. Cancer Research, 74(16), 4270-4281. https://doi.org/10.1158/0008-5472.CAN-13-2817

Creemers, E. E., Tijsen, A. J., \& Pinto, Y. M. (2012). Circulating MicroRNAs. Circulation Research, 110(3), 483-495. https://doi.org/10.1161/circresaha.111.247452

Fernandes, T., Magalh??es, F. C., Roque, F. R., Phillips, M. I., \& Oliveira, E. M. (2012). Exercise training prevents the microvascular rarefaction in hypertension balancing angiogenic and apoptotic factors: Role of microRNAs-16, -21, and -126. Hypertension, 59(2 SUPPL. 1), 513-520. 
https://doi.org/10.1161/HYPERTENSIONAHA.111.185801

Ferreira, J. C., Rolim, N. P., Bartholomeu, J. B., Gobatto, C. A., Kokubun, E., \& Brum, P. C. (2007). MAXIMAL LACTATE STEADY STATE IN RUNNING MICE: EFFECT OF EXERCISE TRAINING. Clinical and Experimental $\begin{array}{lll}\text { Pharmacology and Physiology, 34(8), 760-765. } & \end{array}$ https://doi.org/10.1111/j.1440-1681.2007.04635.x

Frisbee, J. C., Goodwill, A. G., Frisbee, S. J., Butcher, J. T., Brock, R. W., Olfert, I. M., .. Chantler, P. D. (2014). Distinct temporal phases of microvascular rarefaction in skeletal muscle of obese Zucker rats. American Journal of Physiology. Heart and Circulatory Physiology, 307(12), H1714-28. https://doi.org/10.1152/ajpheart.00605.2014

Garzon, R., Marcucci, G., \& Croce, C. M. (2010). Targeting MicroRNAs in Cancer: Rationale, Strategies and Challenges. Nature Reviews Clinical ..., 48(Suppl 2), 1-6. https://doi.org/10.1097/MPG.0b013e3181a15ae8.Screening

Goh, J., Niksirat, N., \& Campbell, K. L. (2014). Exercise training and immune crosstalk in breast cancer microenvironment: exploring the paradigms of exercise-induced immune modulation and exercise-induced myokines, 6(5), 422-438.

Goljanek-Whysall, K., Pais, H., Rathjen, T., Sweetman, D., Dalmay, T., Münsterberg, A., ... Hume, J. R. (2012). Regulation of multiple target genes by miR-1 and miR-206 is pivotal for $\mathrm{C} 2 \mathrm{C} 12$ myoblast differentiation. Journal of Cell Science, 125(Pt 15), 3590-600. https://doi.org/10.1242/jcs.101758

Groarke, J. D., Cheng, S., Jones, L. W., \& Moslehi, J. (2013). Cancer cachexia: getting to the heart of the matter. European Heart Journal, 14-16. https://doi.org/10.1093/eurheartj/eht424

Hanahan, D., \& Weinberg, R. A. (2011). Hallmarks of cancer: The next generation. Cell, 144(5), 646-674. https://doi.org/10.1016/j.cell.2011.02.013

He, W. A., Berardi, E., Cardillo, V. M., Acharyya, S., Aulino, P., Thomas-Ahner, J., ... Guttridge, D. C. (2013). NF-kB-mediated Pax7 dysregulation in the 
muscle microenvironment promotes cancer cachexia. Journal of Clinical Investigation, 123(11), 4821-4835. https://doi.org/10.1172/JCI68523

He, W. a, Calore, F., Londhe, P., Canella, A., Guttridge, D. C., \& Croce, C. M. (2014). Microvesicles containing miRNAs promote muscle cell death in cancer cachexia via TLR7. Proceedings of the National Academy of Sciences of the United States of America, 111(12), 4525-9. https://doi.org/10.1073/pnas.1402714111

Hong, Y., Lee, R. C., \& Ambros, V. (2000). Structure and Function Analysis of LIN-14, a Temporal Regulator of Postembryonic Developmental Events in Caenorhabditis elegans. Molecular and Cellular Biology, 20(6), 2285-2295. https://doi.org/10.1128/MCB.20.6.2285-2295.2000

Horak, M., Novak, J., \& Bienertova-Vasku, J. (2016). Muscle-specific microRNAs in skeletal muscle development. Developmental Biology, 410(1), 1-13. https://doi.org/10.1016/j.ydbio.2015.12.013

Isanejad, A., Alizadeh, A. M., Shalamzari, S. A., Khodayari, H., Khodayari, S., Khori, V., \& Khojastehnjad, N. (2016). MicroRNA-206, Let-7 and microRNA-21 pathways involved in the anti-angiogenesis effects of the interval exercise training and hormone therapy in breast cancer. Life Sciences, 151, 30-40. https://doi.org/10.1016/j.lfs.2016.02.090

Jo, E., \& Salazar, G. (2016). Skeletal Muscle Plasticity In The Colon-26 Murine Model Of Cancer Cachexia. Metabolism, 65(5), 685-698. https://doi.org/10.1016/j.metabol.2016.01.014

Johns, N., Stephens, N. A., \& Fearon, K. C. H. (2013). Muscle wasting in cancer. International Journal of Biochemistry and Cell Biology, 45(10), 2215-2229. https://doi.org/10.1016/j.biocel.2013.05.032

Kaplan, R. N., Riba, R. D., Zacharoulis, S., Bramley, A. H., Vincent, L., Costa, C., ... Lyden, D. (2005). VEGFR1-positive haematopoietic bone marrow progenitors initiate the pre-metastatic niche. Nature, 438(7069), 820-7. https://doi.org/10.1038/nature04186

Khori, V., Amani Shalamzari, S., Isanejad, A., Alizadeh, A. M., Alizadeh, S., Khodayari, S., ... Fayad, R. (2015). Effects of exercise training together 
with tamoxifen in reducing mammary tumor burden in mice: Possible underlying pathway of MIR-21. European Journal of Pharmacology, 765, 179-187. https://doi.org/10.1016/j.ejphar.2015.08.031

Kodama, S., Saito, K., Tanaka, S., Maki, M., Yachi, Y., Asumi, M., ... Sone, H. (2009). Cardiorespiratory fitness as a quantitative predictor of all-cause mortality and cardiovascular events in healthy men and women: a metaanalysis. JAMA, 301(19), 2024-35. https://doi.org/10.1001/jama.2009.681

Lago, C. U., Sung, H. J., Ma, W., Wang, P., \& Hwang, P. M. (2011). P53, Aerobic Metabolism, and Cancer. Antioxidants \& Redox Signaling, 15(6), 1739-48. https://doi.org/10.1089/ars.2010.3650

Lee, R. C., Feinbaum, R. L., \& Ambros, V. (1993). The C. elegans heterochronic gene lin-4 encodes small RNAs with antisense complementarity to lin-14. Cell, 75(5), 843-854. https://doi.org/10.1016/0092-8674(93)90529-Y

Li, L., Sarver, A. L., Alamgir, S., \& Subramanian, S. (2012). Downregulation of microRNAs miR-1, -206 and -29 stabilizes PAX3 and CCND2 expression in rhabdomyosarcoma. Laboratory Investigation, 92(4), 571-583. https://doi.org/10.1038/labinvest.2012.10

Liu, N., Williams, A. H., Maxeiner, J. M., Bezprozvannaya, S., Shelton, J. M., Richardson, J. a., ... Olson, E. N. (2012). microRNA-206 promotes skeletal muscle regeneration and delays progression of Duchenne muscular dystrophy in mice. Journal of Clinical Investigation, 122(6), 2054-2065. https://doi.org/10.1172/JCl62656DS1

Luo, Y., Wu, X., Ling, Z., Yuan, L., Cheng, Y., Chen, J., \& Xiang, C. (2015). microRNA133a targets Foxl2 and promotes differentiation of $\mathrm{C} 2 \mathrm{C} 12$ into myogenic progenitor cells. DNA and Cell Biology, 34(1), 29-36. https://doi.org/10.1089/dna.2014.2522

Ma, J., Lanza, D. G., Guest, I., Uk-Lim, C., Glinskii, A., Glinsky, G., \& Sell, S. (2012). Characterization of mammary cancer stem cells in the MMTVPyMT mouse model. Tumor Biology, 1-14. https://doi.org/10.1007/s13277012-0458-4 
Mishra, S. I., Scherer, R. W., Snyder, C., Geigle, P., \& Gotay, C. (2014). Are exercise programs effective for improving health-related quality of life among cancer survivors? A systematic review and meta-analysis. Oncology Nursing Forum, 41(6), E326-42. https://doi.org/10.1188/14.ONF.E326-E342

Miyoshi, K., Miyoshi, T., \& Siomi, H. (2010). Many ways to generate microRNAlike small RNAs: non-canonical pathways for microRNA production, 95103. https://doi.org/10.1007/s00438-010-0556-1

Mooren, F. C., Viereck, J., Kruger, K., \& Thum, T. (2014). Circulating microRNAs as potential biomarkers of aerobic exercise capacity. American Journal of physiology. Heart and Circulatory Physiology, 306(4), H557--63. https://doi.org/10.1152/ajpheart.00711.2013

Mukherjee, S. (2010). O IMPERADOR DE TODOS OS MALES, uma biografia do câncer. PhD Proposal, 1. https://doi.org/10.1017/CBO9781107415324.004

Neil-Sztramko, S. E., Kirkham, A. A., Hung, S. H., Niksirat, N., Nishikawa, K., \& Campbell, K. L. (2014). Aerobic capacity and upper limb strength are reduced in women diagnosed with breast cancer: a systematic review. Journal of Physiotherapy, 60(4), 189-200. https://doi.org/10.1016/j.jphys.2014.09.005

Nicoletti, I., Zanolla, L., Brighetti, G., \& Zaedini, P. (2003). Skeletal Muscle Abnormalities in Chronic Heart Failure Patients: Relation to Exercise Capacity and Therapeutic Implications. Congestive Heart Failure (Greenwich, Conn.), 9(June), 148-154.

Pedersen, L., Idorn, M., Pedersen, B. K., Straten, P., Hojman, P., Pedersen, L., ... Hansen, R. H. (2016). Short Article Voluntary Running Suppresses Tumor Growth through Epinephrine- and IL-6-Dependent NK Cell Short Article Voluntary Running Suppresses Tumor Growth through Epinephrineand IL-6-Dependent, 1-9. https://doi.org/10.1016/j.cmet.2016.01.011

Peel, A. B., Thomas, S. M., Dittus, K., Jones, L. W., \& Lakoski, S. G. (2014). Cardiorespiratory fitness in breast cancer patients: a call for normative values. Journal of the American Heart Association, 3(1), 1-9. 
https://doi.org/10.1161/JAHA.113.000432

Peinado, H., Alečković, M., Lavotshkin, S., Matei, I., Costa-Silva, B., MorenoBueno, G., ... Lyden, D. (2012). Melanoma exosomes educate bone marrow progenitor cells toward a pro-metastatic phenotype through MET. Nature Medicine, 18(6), 883-91. https://doi.org/10.1038/nm.2753

Reis, D., Walsh, M. E., Young-McCaughan, S., \& Jones, T. (2013). Effects of $\mathrm{Nia}$ exercise in women receiving radiation therapy for breast cancer. Oncology Nursing Forum, 40(5), E374-81. https://doi.org/10.1188/13.ONF.E374-E381

Repka, C. P., Peterson, B. M., Brown, J. M., Lalonde, T. L., Schneider, C. M., \& Hayward, R. (2014). Cancer type does not affect exercise-mediated improvements in cardiorespiratory function and fatigue. Integrative Cancer Therapies, 13(6), 473-81. https://doi.org/10.1177/1534735414547108

Roque, F. R., Hernanz, R., Salaices, M., \& Briones, A. M. (2013). Exercise training and cardiometabolic diseases: focus on the vascular system. Current Hypertension Reports, 15(3), 204-14. https://doi.org/10.1007/s11906-013-0336-5

Ruas, J. L., White, J. P., Rao, R. R., Kleiner, S., Brannan, K. T., Harrison, B. C., ... Spiegelman, B. M. (2012). A PGC-1?? isoform induced by resistance training regulates skeletal muscle hypertrophy. Cell, 151(6), 1319-1331. https://doi.org/10.1016/j.cell.2012.10.050

Safdar, A., Saleem, A., \& Tarnopolsky, M. A. (2016). The potential of endurance exercise-derived exosomes to treat metabolic diseases. Nature Reviews. Endocrinology. https://doi.org/10.1038/nrendo.2016.76

Schnyder, S., \& Handschin, C. (2015). Skeletal muscle as an endocrine organ: PGC-1??, myokines and exercise. Bone, 80, 115-125. https://doi.org/10.1016/j.bone.2015.02.008

Shao, Y., Geng, Y., Gu, W., Huang, J., Pei, H., \& Jiang, J. (2015). Prognostic role of tissue and circulating MicroRNA-200c in malignant tumors: A systematic review and meta-analysis. Cellular Physiology and Biochemistry, 35(3), 1188-1200. https://doi.org/10.1159/000373943 
Siegel, R., Desantis, C., Virgo, K., Stein, K., Mariotto, A., Smith, T., ... Fedewa, S. (2013). Cancer Treatment and Survivorship Statistics , 2012, O(0), 1-22. https://doi.org/10.3322/caac.21149.

Soares, R. J., Cagnin, S., Chemello, F., Silvestrin, M., Musaro, A., De Pitta, C., ... Sandri, M. (2014). Involvement of MicroRNAs in the regulation of muscle wasting during catabolic conditions. Journal of Biological Chemistry, 289(32), 21909-21925. https://doi.org/10.1074/jbc.M114.561845

Soci, U. P. R., Fernandes, T., Hashimoto, N. Y., Mota, G. F., Amadeu, M. a, Rosa, K. T., ... Oliveira, E. M. (2011). MicroRNAs 29 are involved in the improvement of ventricular compliance promoted by aerobic exercise training in rats. Physiological Genomics, 43(11), 665-673. https://doi.org/10.1152/physiolgenomics.00145.2010

Tisdale, M. J. (2009). Mechanisms of cancer cachexia. Physiological Reviews, 89(2), 381-410. https://doi.org/10.1152/physrev.00016.2008

Townley-Tilson, W., Callis, T., \& Wang, D. (2010). MicroRNAs 1, 133, and 206: critical factors of skeletal and cardiac muscle development, function, and disease. International Journal of Biochemistry \& Cell Biology, 42(8), 12521255. https://doi.org/10.1016/j.biocel.2009.03.002

van Rooij, E., Purcell, A. L., \& Levin, A. A. (2012). Developing MicroRNA Therapeutics. Circulation Research, 110(3), 496-507. https://doi.org/10.1161/CIRCRESAHA.111.247916

Waning, D. L., Mohammad, K. S., Reiken, S., Xie, W., Andersson, D. C., John, S., ... Guise, T. A. (2015). Excess TGF- $\beta$ mediates muscle weakness associated with bone metastases in mice. Nature Medicine, 21(11), 126271. https://doi.org/10.1038/nm.3961

Weinberg, R. A. (1989). Oncogenes, antioncogenes, and the molecular bases of multistep carcinogenesis. Cancer Research, 49(14), 3713-21. Retrieved from http://www.ncbi.nlm.nih.gov/pubmed/2660980

Winter, J., Jung, S., Keller, S., Gregory, R. I., \& Diederichs, S. (2009). Many roads to maturity: microRNA biogenesis pathways and their regulation. Nature Cell Biology, 11(3), 228-234. https://doi.org/10.1038/ncb0309-228 
Yu, H., Lu, Y., Li, Z., \& Wang, Q. (2014). microRNA-133: expression, function and therapeutic potential in muscle diseases and cancer. Current Drug Targets, 15(9),

817-828. https://doi.org/10.2174/1389450115666140627104151

Yuan, J., Yang, F., Wang, F., Ma, J., Guo, Y., Tao, Q., .. Sun, S. H. (2014). A long noncoding RNA activated by TGF- $\beta$ promotes the invasion-metastasis cascade in hepatocellular carcinoma. Cancer Cell, 25(5), 666-81. https://doi.org/10.1016/j.ccr.2014.03.010

Zhou, W., Fong, M. Y., Min, Y., Somlo, G., Liu, L., Palomares, M. R., ... Wang, S. E. (2014). Cancer-Secreted miR-105 destroys vascular endothelial barriers to promote metastasis. Cancer Cell, 25(4), 501-515. https://doi.org/10.1016/j.ccr.2014.03.007

Zimmers, T. A., Fishel, M. L., \& Bonetto, A. (2016). STAT3 in the systemic inflammation of cancer cachexia. Seminars in Cell \& Developmental Biology, 54, 28-41. https://doi.org/10.1016/j.semcdb.2016.02.009 